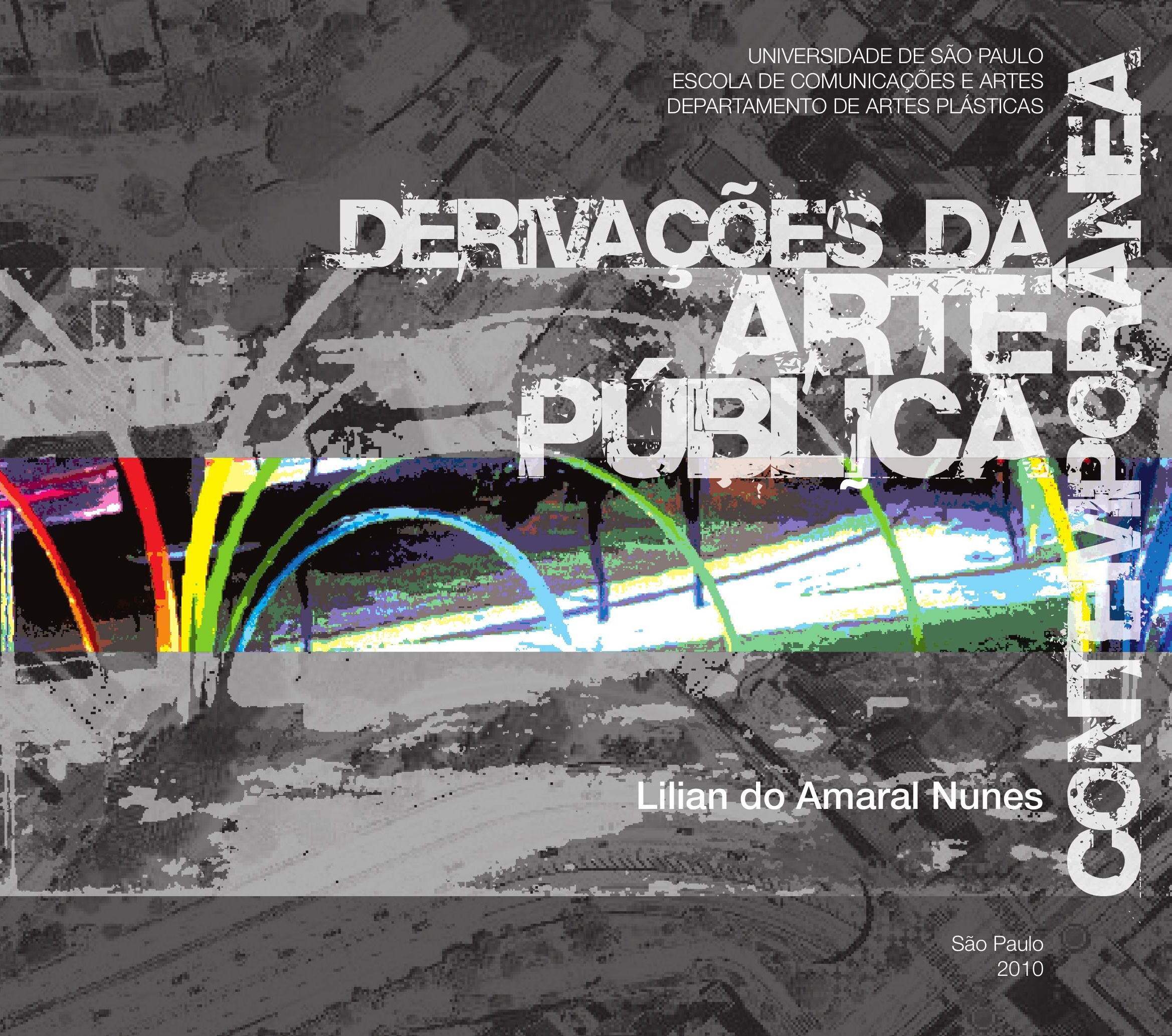



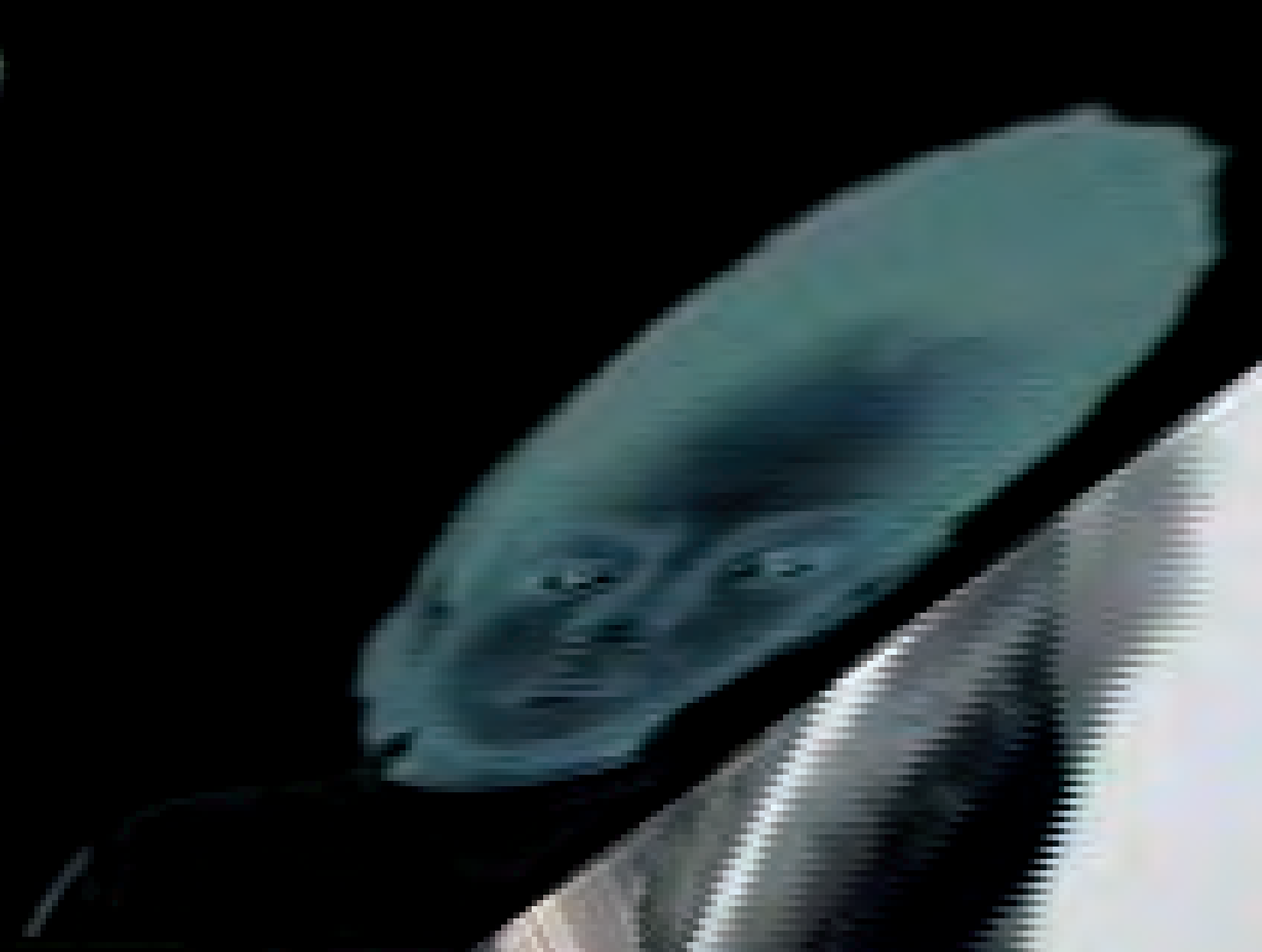

UNIVERSIDADE DE SÃO PAULO ESCOLA DE COMUNICAÇÕES E ARTES

DEPARTAMENTO DE ARTES PLÁSTICAS

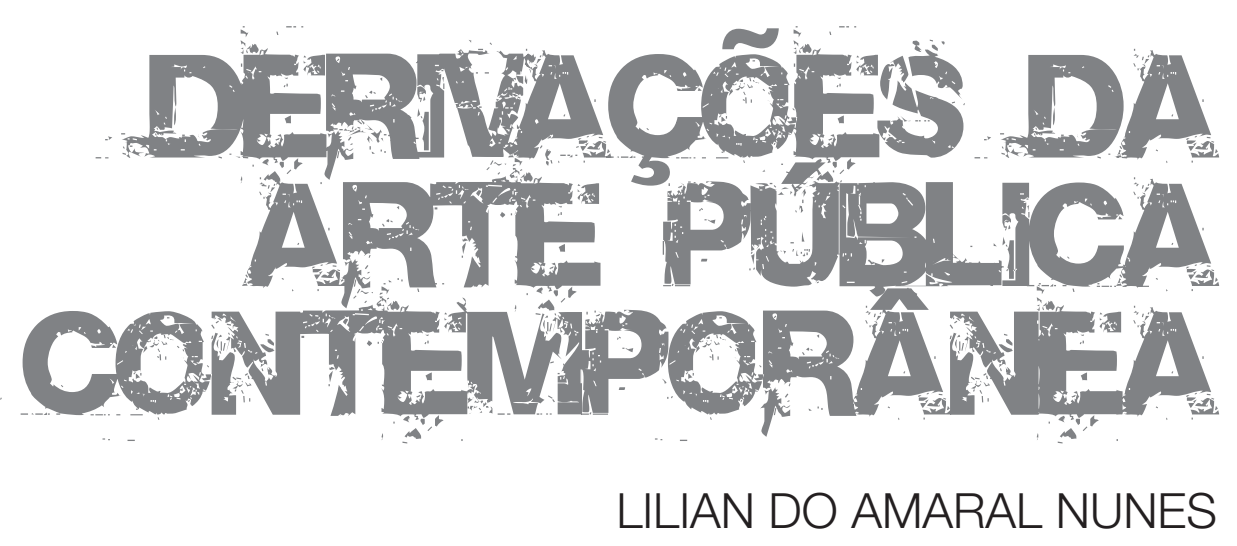

São Paulo 

UNIVERSIDADE DE SÃO PAULO

ESCOLA DE COMUNICAÇÃO E ARTES - ECA

PROGRAMA DE PÓS-GRADUAÇÃO EM ARTES VISUAIS

\section{DERIVAÇÕES DA ARTE PÚBLICA CONTEMPORÂNEA}

LILIAN DO AMARAL NUNES

Tese apresentada ao Programa de PósGraduação em Artes Visuais, Área de Concentração Artes Visuais. Linha de Pesquisa Teoria, Ensino e Aprendizagem da Arte, da Escola de Comunicações e Artes da Universidade de São Paulo, como requisito para obtenção do Título de Doutora em Artes.

Orientadora: Profa. Dra. Ana Mae Tavares Bastos Barbosa. 



\section{FOLHA DE APROVAÇÃO}

Lilian do Amaral Nunes

Derivações da arte pública contemporânea

Tese apresentada à Escola de Comunicações e Artes da Universidade de São Paulo para obtenção do título de Doutora.

Área de Concentração: Artes Visuais.

Aprovada em:

\section{BANCA EXAMINADORA}

Profa. Dra. Lucimar Bello Pereira Frange

Instituição: Assinatura:

Profa. Dra. Maria Beatriz de Medeiros

Instituição: Assinatura:

Prof. Dr. Gillberto dos Santos Prado

Instituição: Assinatura:

Profa. Dra. Maria Christina de Souza Rizzi

Instituição: Assinatura:

Profa. Titular Ana Mae Tavares Bastos Barbosa

Instituição: Assinatura: 

Ao Márcio, meu amor, amigo, parceiro.

Yuri e Albin, inspirações.

Aos meus pais, exemplos e ensinamentos.

Sem eles a vida seria uma aventura ainda mais perigosa. 

Agradeço imensamente a minha querida orientadora Ana Mae Barbosa, por seu exemplo de vida, estímulo e caminhos apontados, pelo encorajamento manifesto desde que nos conhecemos nos anos oitenta, em direção à Arte Pública e inserção social, pelas sugestões atentas e por acreditar no projeto e trajetória.

Agradeço o acolhimento, o apoio e a interlocução de minha co-orientadora e amiga Marián Lopez Fernandez Cao, diretora do Instituto de Estudos Feministas e Coordenadora principal do programa Interuniversitário de Doutorado "Aplicaciones del Arte en la Integración Social: Arte, memória e identidad", da Universidad Complutense de Madrid, que com sua atuação e performance institucional nos instigou a acreditar cada vez mais no poder da atuação das mulheres, e que por meio do Programa de Mobilidade Internacional SANTANDER / USP, com o qual fomos contempladas, proporcionou o aprofundamento das questões interculturais e interterritoriais implicadas na presente investigação.

Agradeço à Christina Rizzi e Edgard de Assis Carvalho pela acurada leitura do texto de qualificação e pela atenção e acompanhamento destas mais de duas décadas de atuação compartilhada. À Christina Rizzi, em especial, pelo entendimento do alcance e espeficidade do trabalho, fundado na idéia de um antimuseo, museu de experiências, museu essencial.

Aos queridos professores, pesquisadores e artistas Gilbertto Prado e Maria Beatriz de Medeiros, por suas sugestões, práticas criticas e institucionais, companheiros no campo da pesquisa em Artes, e por seus exemplos de prática docente.

Às professorasElizabethSaade Branca deOliveira, pelascontribuições e ampliações de horizontes no decorrer da investigação. 
Ao amigo Daniel Toso, pela generosidade e disposição de enfrentar o desconhecido e mergulhar de cabeça nos territórios da arte pública.

À Liliana Magalhães e sua brilhante equipe do Santander Cultural - Maria Bastos, Patrícia Scorssi, Leliane, por acreditarem, apoiarem e concretizarem o Simpósio Internacional Porto Alegre Cidade Criativa, possibilitando o intercâmbio com pesquisadores, curadores e artistas espanhóis, fortalecendo ainda mais os laços e compartilhamentos qualificados, projetando futuros enraizados em profícuas práticas no presente.

À amiga Lucimar Bello, pelas crenças e práticas artísticas e pedagógicas, pelo que já fizemos e ainda realizaremos conjuntamente no campo da estética relacional.

Ao Danilo Miranda, por sempre ter acreditado na Arte Pública como possibilidade de diálogo cultural e na interterritorialidade como forma de entranhar fronteiras, crenças, contextos e promover transformações.

À Elaine e Roger, pelo afeto manifesto na esmerada revisão e design gráfico, pela criatividade, cumplicidade e amizade.

E ao Marcio. Sem ele seria impossivel. 
Agradecimentos Especiais referentes ao Museu Aberto / Casa da Memória: Núcleo da Memória Audiovisual da Paisagem Humana de Paranapiacaba

Albina Cusmanich Ayala - Alessandra Maiello - Ana Mae Barbosa - André Costa/Olhar Periférico - Aziz Ab Saber - Benedito Lima de Toledo - Bia Medeiros/Corpos Informáticos - Carlos Alberto Dêgelo - Daniel Toso - Djalma Honório - Didonet Thomaz - Diná Jobst - Edgard de Assis Carvalho - Elizabeth Chanampa - Expedito Pedro - Fabíola Aliceda - Frederico Dalton - Issao Minami - Julio Abe Wakahara - Julio César Palacio - Katherine Bash - Marco Moretto - Marcos Imbrizi - Maria Valéria Bonim - Mônica Cardella - Nelson Ricardo Martins - Rodolfo Nakamura - Rogério Nagaokal Espaço Coringa - Rogério Augusto - Paula Caetano - Priscila Arantes - Sônia Freitas - Xico Chaves - Wilson Rodrigues

Aos AGENTES DA MEMÓRIA - Moradores e Colaboradores da Vila de Paranapiacaba e à Equipe Técnica da Sub-Prefeitura de Paranapiacaba e Parque Andreense - Prefeitura de Santo André. 


\section{Aos Colaboradores / Parceiros Institucionais}

Associação Cultural Vídeobrasil

Escola de Comunicação e Artes - Universidade de São Paulo

Curso de Hotelaria e Turismo, Curso de Cinema e Estúdio de Vídeo, Foto e Som - Universidade Anhembi Morumbi

Faculdade de Arquitetura e Urbanismo - Universidade de São Paulo

POCS Barcelona

Rede Nacional de Artes Visuais FUNARTE

Revista Malabia Argentina

Secretaria de Estado da Cultura de São Paulo - Departamento de Museus e Arquivos

Sub-Prefeitura de Paranapiacaba e Parque Andreense / Prefeitura de Santo André 
"Os processos são os devires, e estes não se julgam pelo resultado que os findaria, mas pela qualidade de seus cursos e pela potência de sua continuação (...)."

Giles Deleuze, Conversações.

"A experiência que passa de pessoa a pessoa é a fonte a que recorrem todos os narradores. E, entre as narrativas escritas, as melhores são as que menos se distinguem das histórias orais contadas pelos inúmeros narradores anônimos."

Walter Benjamin, "O narrador" em Magia e Técnica, Arte e Política: ensaios sobre literatura e história da cultura. 



\section{RESUMO}

AMARAL, Lilian. Derivações da Arte Pública Contemporânea. 2010. Tese (Doutorado) - Escola de Comunicações e Artes, Universidade de São Paulo, São Paulo, 2010. 196 p.

Projeto de investigação transdiciplinar com ênfase nas atuais abordagens dialógicas estabelecidas entre arte e esfera pública.

Discute o estatuto contemporâneo da Arte Pública e decorrentes hibridizações bem como do museu como espaço de investigação e interlocução artística, com base em ações e experiências processuais e colaborativas.

Desenvolve procedimentos inspirados nas práticas museais, tendo os imaginários urbanos como território de análise, configurando novas arqueologias da memória urbana contemporânea. Do espetáculo à experiência da cidade, passa-se às diferenças entre visualidade e visibilidade, passa-se da cidade ao lugar. Opera-se uma distinção entre visualidade e visibilidade, entre recepção e percepção, entre comunicação e informação. Em todas essas diferenças se produzem metamorfoses do olhar.

\section{Palavras-chave}

Arte colaborativa, arte e esfera pública, arte pública, arte comunitária, visualidade/visibilidade. 



\section{ABSTRACT}

AMARAL, Lilian. Contemporary Public Art's Derivations. 2010. Thesis (Doctoral) - Escola de Comunicações e Artes, Universidade de São Paulo, São Paulo, 2010. 196 p.

Transdisciplinary research project focused on contemporary dialogic aproach based on art and public sphere.

It discusses the role of contemporary Public Arte and current hybridizations as well as the museum as a research's space and artistic conversation.

It develops procedures inspired on museum practices and it has the urban imaginaries as territories of analyses, configurating new archeologys of contemporary urban memory. From the spectacle to the city's experience, it pass through differences betwenn visuality and visibility, the city and the site. It operates a distinction between visuality and visibility, reception and perception, communication and information. In all those differences metamorphosys of the look are produced.

\section{Key-words}

Collaborative art, art and public sphere, public art, community art, visuality/visibility. 


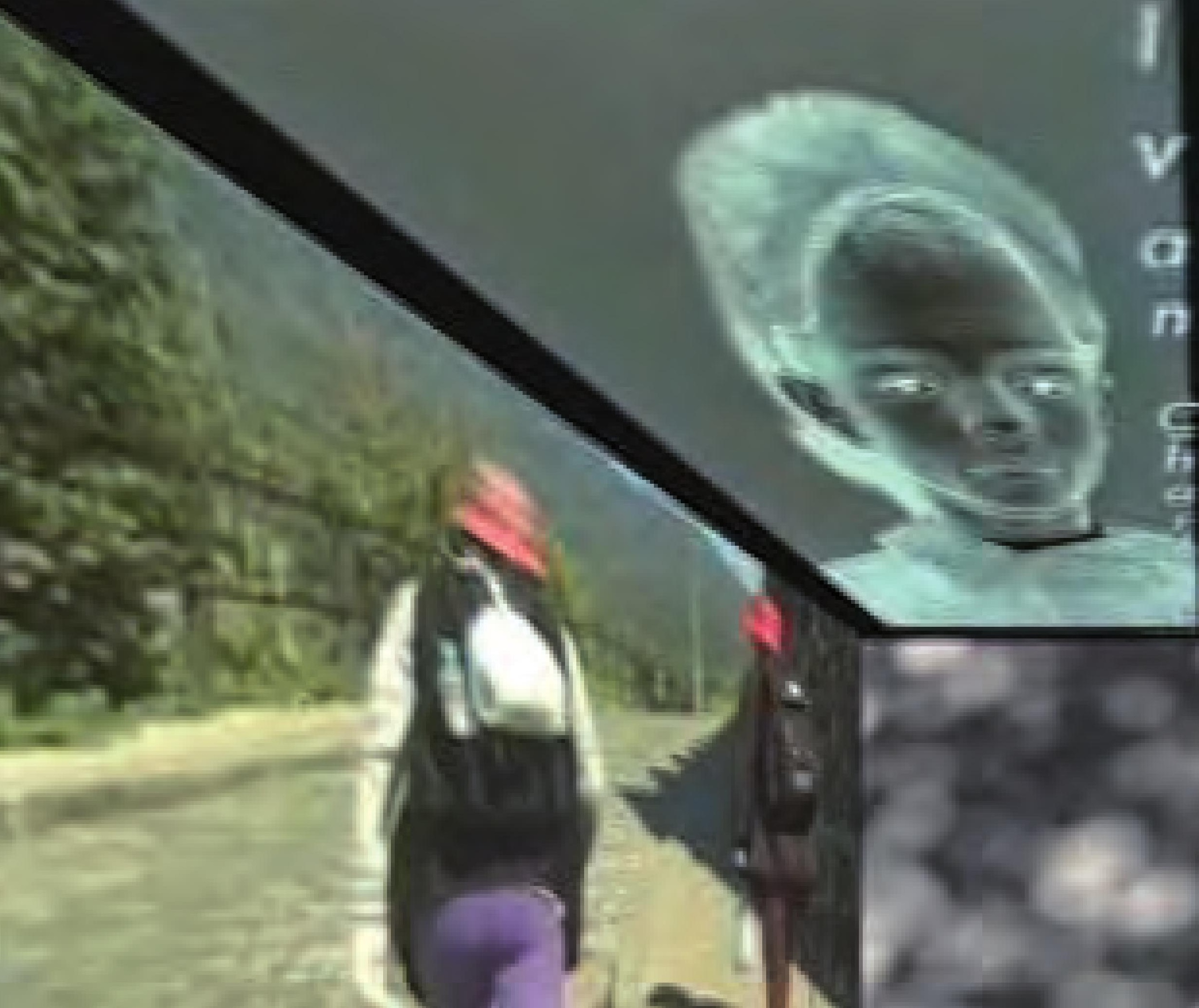




\section{aㅏ

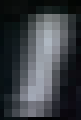 \\ I \\ f \\ TH \\ H. \\ - \\ 다

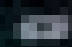 \\ DI

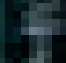 \\ 단}

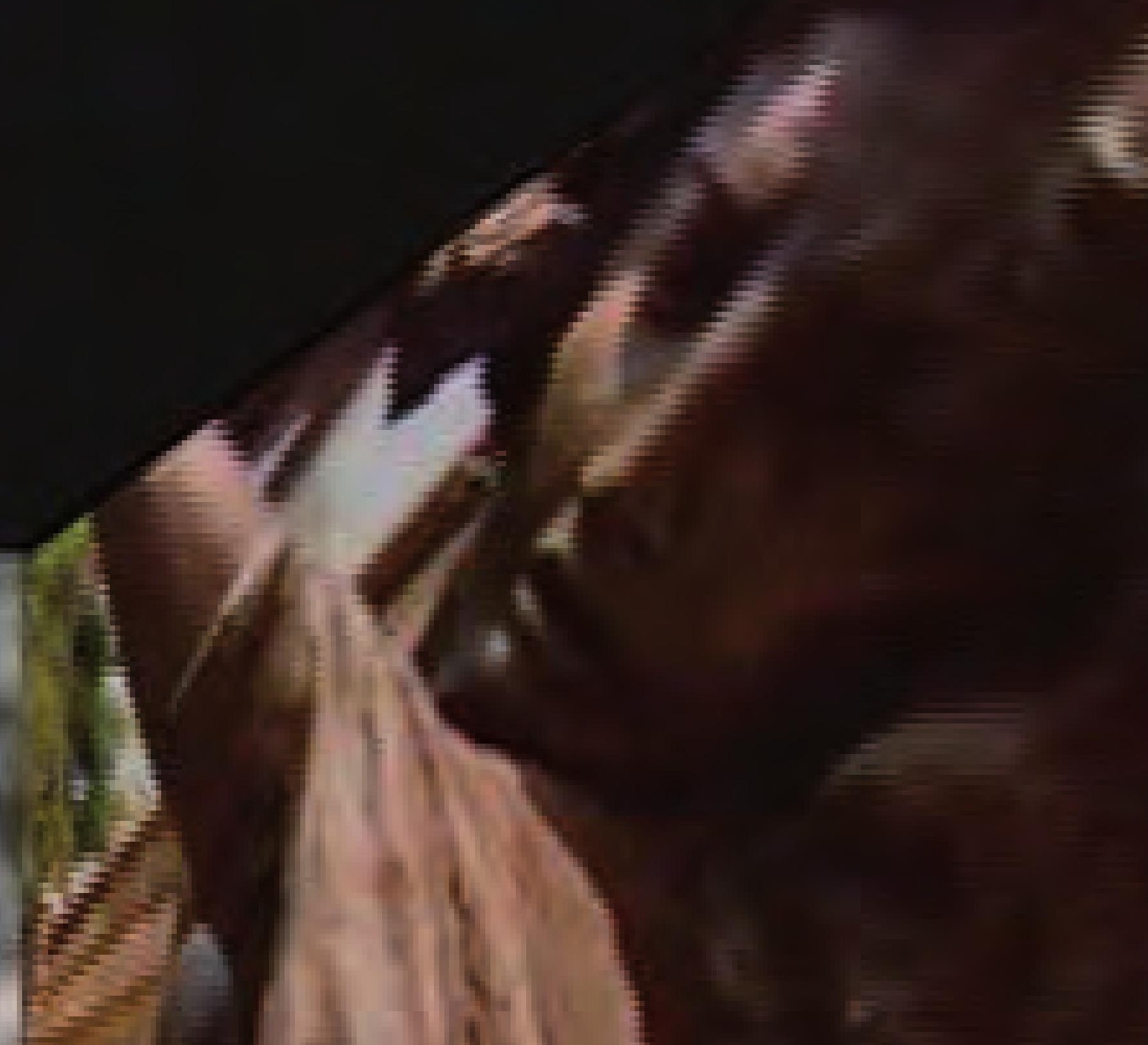




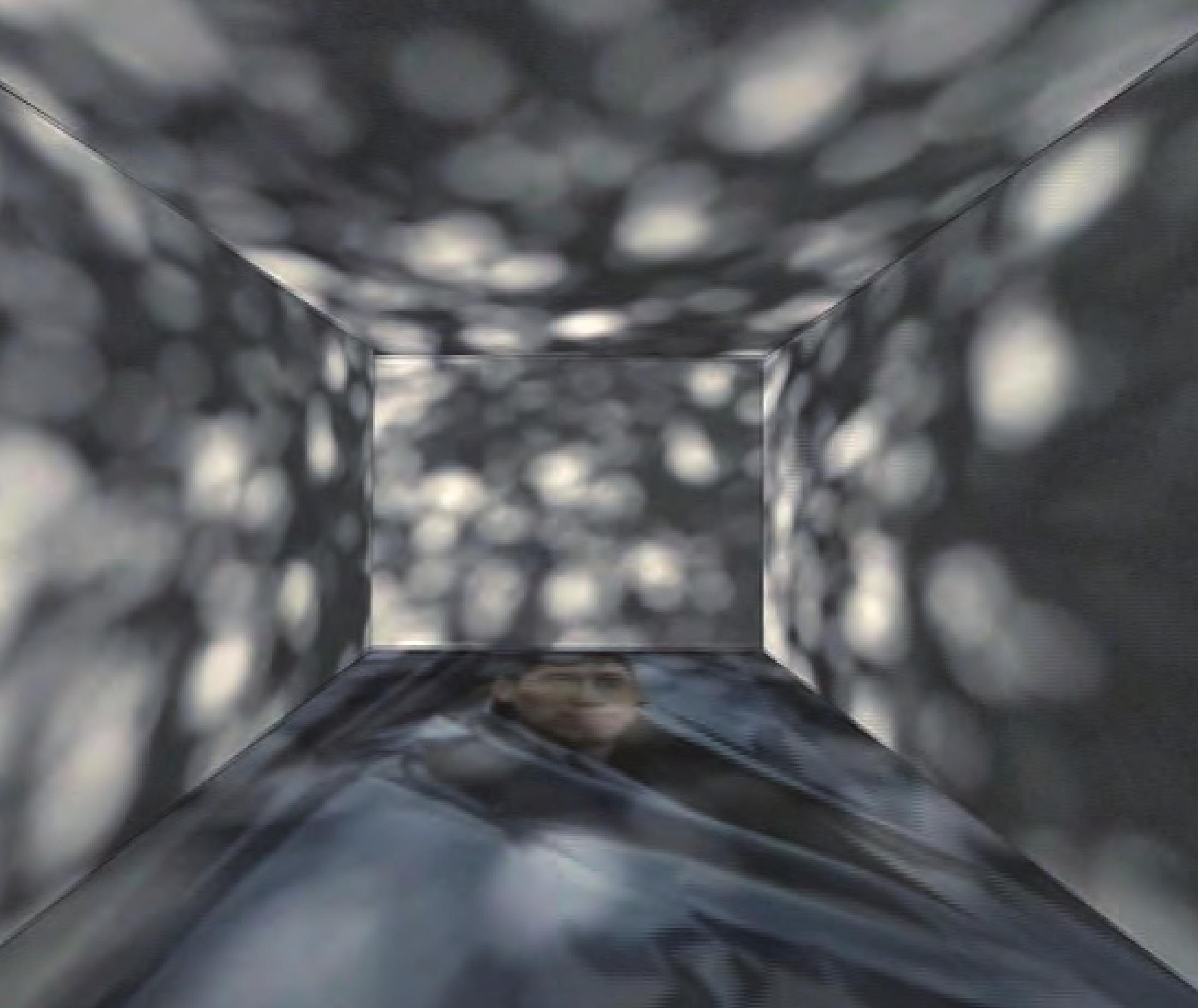




\section{SUMMÁRIO}

INTRODUÇÃO

CAPITULO 1 - ARTE E ESFERA PÚBLICA

1.1 Arte e Contexto: Por uma definição de Espaço Público e Arte Pública 31

1.2 Arte Pública: Derivações Contemporâneas 35

1.3 Arte Pública: Especificidade em relação ao local de origem e sua especificidade nas memórias coletivas

1.4 A Especificidade do Lugar da obra como prática crítica 39

CAPITULO 2 - LIMITES DIFUSOS; DESLOCAMENTOS E IMPLICAÇÕES DA ARTE PÚBLICA CONTEMPORÂNEA

2.1 Arte Pública e Comunidade: Origens e evolução das práticas artísticas colaborativas 47

2.2 Contexto Social da Arte e Participação: olhando em direção aos anos setenta 49

2.3 A Arte no Contexto Urbano: Por uma Cultura do Diálogo 52

2.4 A Transformação da Arte no âmbito educativo e institucional 57

2.5 Questionamentos: Dilemas e tensões presentes nas práticas colaborativas contemporâneas 61

Capítulo 3 - ARTE, EXPERIÊNCIA E TERRITÓRIOS EM PROCESSO

3.1 MUSEU ABERTO: Um Projeto em Processo $\quad 75$

3.1.1 Museu Aberto: Origens e Confluências. Diálogos entre Arte e Meio Ambiente 77

3.1.2 Museu Aberto: Arte Contemporânea, Cotidiano Urbano e Transformação Social 98

3.1.3 Estudo de Caso: Museu Aberto: a cidade como Museu e o Museu como prática artística $\quad 101$

3.2 Arte em Processo: o documentário como Plataforma para Construção de Narrativas Coletivas 135

3.2.1 Expansão de Fronteiras: 0 estatuto da imagem documental na contemporaneidade 138

3.3 Derivações da Arte Pública Contemporânea em Contextos Interculturais Ibero-americanos. 141

3.4 Transversalidades Interculturais, Projetos processuais, Mudanças epistemológicas 145

3.5 Configurando Redes e o Trabalho Colaborativo no Campo das Artes Visuais: Redes Sociais, memória, Arquivo e Acesso 
3.6 Arte e Esfera Pública Contemporânea: Panorama de Mutabilidade

3.6.1 Pesquisa e Produção Artística

3.6.2 Museu Aberto: a cidade como museu e o museu como prática artística

3.7 Jornadas Abertas Interculturais: Workshops Internacionais de Arte Pública Contemporânea 


\section{INTRODUCÇÃO}

A presente investigação contempla abordagens que buscam delinear um campo de prática crítica para a Arte Pública no Brasil em diálogo com experiências internacionais.

Percorre, como fio condutor, nossa prática artística, investigativa e curatorial, configurada pelo projeto processual Museu Aberto, a partir das interfaces com a arte ambiental e questões museológicas, e para tanto, toma os museus e espaços públicos na cidade de São Paulo, a partir dos anos oitenta, como contexto, corpo poético e espaço de estudo-intervenção. Na contemporaneidade, constitui uma plataforma teórico-prática que tem nos imaginários urbanos, nas memórias coletivas, nos arquivos e nas práticas documentais seus dispositivos de operação.

Como contraponto, analisa experiências e revisa o significado da expressão arte comunitária, surgida nos anos setenta, principalmente nos EUA ena Inglaterra para descrever determinadas práticas artísticas que implicam na colaboração e participação do público na obra, assim como a intenção de alcançar uma melhoria social através da arte. Descreve o contexto e as idéias artísticas que lhe servem de base, concretamente duas: a importância do contexto social da obra e do envolvimento do espectador. A Arte Comunitária evolui em direção aos âmbitos institucionais e educativos nos anos posteriores e se converte, também, em uma referência para a Arte Pública Contemporânea.

Finalmente, descreve as principais problemáticas associadas às práticas artísticas colaborativas em contextos Ibero-americanos, as quais se estruturam a partir da estética relacional, da arte contextual e da interterritorialidade. 




\section{CAPITULO I \\ ARTE E ESFERA}

\subsection{ARTE E CONTEXTO: POR UMA DEFINIÇÃO DE ESPAÇO PÚBLICO E ARTE POLÍTICA}

A arte como instância pública ou social está redefinindo conceitos como os de arte pública e espaço público. A partir dos anos oitenta, o conceito de arte pública se vincula ao espaço público. Fala-se de arte em lugares públicos ou de arte em contexto. É evidente que cada vez mais se é exigente com o conceito de "público", que tem conotações altamente democráticas. Assim, o que é público implica em "abertura", "acessibilidade", "participação", "inclusão" e, definitivamente, leva em consideração as pessoas, não somente como espectadores ou visitantes, mas como usuários e construtores do espaço público e que podem ser parte ativa em sua configuração..

As discussões e os discursos emergentes sobre o novo conceito de arte pública estão intimamente ligados a um "comportamento democrático" ao redor da arte, da arquitetura e dos espaços urbanos. 0 espaço público faz parte da retórica democrática, um lugar comum para exercer os direitos que dela derivam, ainda que sirva para dar suporte a um urbanismo irracional. 0 espaço público define-se por contraposição ao espaço privado alicerçado na 
propriedade, com base na liberdade, na igualdade, na participação e o ativismo como forma reconhecida de participação.

Esta ideia de espaço público, própria das democracias mais conservadoras, tem se transformado na medida em que os anos oitenta do século XX avançaram no marco de um contexto de desenvolvimento urbano massivo acelerado, que corresponderia a um neocapitalismo avançado, baseado na exploração e na opressão do espaço urbano e de seus habitantes. Este sistema tem transformado as cidades em espaços de proveito privado sob um controle público, criando bolsas urbanas de desamparados, uma vez que o desenvolvimento e a reestruturação dos espaços urbanos tem destruido sistemas precários de sobrevivência nas grandes cidades. Contudo, neste contexto, a arte tem tido um papel de elemento de coesão, considerando que aspectos de monumentalização, decoração, embelezamento do espaço público estão em declive.

A arte pública tem modificado sua função política, e o que poderiamos chamar de "nova arte pública" surge do conflito e da opressão que geram os novos espaços urbanos. A partir dos anos sessenta e setenta, a abordagem interdisciplinar da arte tem transformado a prática artística em uma prática mais alijada do objeto artístico, outorgando-Ihe uma dimensão política e social evidenciada, dado que se entende a prática de arte como uma prática crítica. Se ao conceito de espaço público acrescentamos o de esfera pública, na qual os cidadãos podem criar estados de opinião críticos contra o estado, o sistema ou a instituição estabelecida, neste contexto, a arte crítica converte-se em elemento-chave para interferir na esfera pública, convertendo o espaço público em espaço político. É quase uma condição sine qua non que a arte pública tenha lugar fora dos espaços institucionais da arte, qual seja, "fora do museu", para garantir sua qualidade pública e total e o livre acesso. É evidente que o espaço do museu cai na parcialidade e privacidade e que uma autêntica ação crítica 
de arte contexto só pode ter lugar fora dos muros dos museus e da instituição artística.

Muitos dos trabalhos contextuais produzidos efetivamente consideram, precisamente, a dicotomia espaço público/espaço privado como ponto de conflito. Outros têm tomado o espaço comunitário como espaço de interação, identidade, comunicação e participação. A arte gera novos instrumentos para ativar a intervenção no espaço público e se converte em uma ferramenta de participação democrática na resolução dos conflitos, minimizando a distância entre o cidadão e o contexto, mediante a formação e organização de coletivos sociais e educativos.

Os anos setenta impulsionaram as práticas artísticas a partir da arte expandida e da hiper-realidade social, criando novas formas de implicação da arte com a sociedade, ativando disciplinas como a sociologia, a psicologia, as ciências da comunicação e outras, as quais, em interação com os processos e a sensibilidade artísticas têm desembocado em uma fusão da arte com a realidade.

A arte pública pode identificar-se com o espaço físico da cidade, naquilo que é o urbano, mas o espaço público responde a um conceito mais amplo, nem sempre referido a um espaço físico, sobretudo quando se desenvolve em um marco da esfera pública, em que um conjunto de cidadãos (ou não-cidadãos), por meio de suas entidades ou instituições, inicia um debate acerca de conceitos que o afetam, segundo um tema de direitos humanos, de identidade ou de questionamento do sistema estabelecido, dentre outros. Ainda, espaço público pode ser, contudo, de ordem imaterial, um espaço onde as relações sociais tenham sentido e, portanto, pode se deslocar facilmente de um território físico a um conceitual. 0 espaço público pode ser definido como um "contenedor de processos sociais ou a expressão material das relações socioeconômicas". 0 espaço não é dado a priori, mas construido com limites e fronteiras que definem sua presença.

Esta concepção do espaço coloca em jogo a problemática destas 
duas concepções de espaço público, a que se refere ao espaço físico urbano (um passeio público, um parque urbano, uma periferia metropolitana, um bairro ou uma praça) e a que afeta o espaço social, seu discurso e sua representação. 0 espaço público é frágil e é fácil que ali sejam produzidas a violência e a exclusão. As alternativas que se oferecem a partir da arte para tratar o espaço público como espaço físico, como discurso ou representação da esfera pública ou de ambos os campos ao mesmo tempo, são propostas complexas que mobilizam processos de comunicação e construção social por meio do espaço público e dos coletivos sociais e educativos.

Mediante experiências processuais de arte pública, cria-se uma relação artística de cumplicidade com o contexto e seus efeitos sociais, gerando assim um debate público e o trabalho em questão se converte em espaço de debate político, criando-se espaços de negociação entre a sociedade, as estruturas públicas e os coletivos da população. A experiência de arte pública convertese, finalmente, em um trabalho de arte política no âmbito do que é "real", seja espaço físico ou representado. 0 retorno ao real anunciado por Hal Foster mediante a tarefa do "artista como etnógrafo" é agora uma prática real, o cumprimento de uma dimensão utópica do espaço público que o situacionismo internacional centra na psicogeografia do espaço urbano, como lugar onde se resolvem os conflitos. Agora, a partir do conflito, as novas práticas artísticas ajudam a criar novas vias de construção social e a minimizar as distâncias com base no diálogo e na colaboração como instrumentos.

Arte e esfera pública criam um novo ativo dentro do espaço político e social que se fundem com as utopias e o espirito criativo e sensivel da arte. Uma nova visão, também democrática da arte, uma vez desaparecidas as figuras da autoria e o gênio romântico. Provavelmente, no século XXI, entramos em uma nova era de cumprimento da "escultura social" anunciada profeticamente por Joseph Beyus nos anos sessenta do século XX. 


\subsection{ARTE PÚBLICA: DERIVAÇÕES CONTEMPORÂNEAS}

Partilhamos da ideia sobre a arte contemporânea como sendo uma "ultrapassagem" que constroi no construido, que tem entre suas funções a resistência, entendida como questionamento constante dos próprios limites, dos próprios axiomas, do próprio lugar, por colocar-se fora dos limites tradicionais, seja na relação com o público, seja na realização, que utiliza o disfarce, a negação, o hibridismo, a contestação e a transformação.

Entendemos que longe de exercer a função negativa (própria do movimento vanguardista), a arte contemporânea coloca em pauta a existência humana, focalizando não a duração, mas o acontecimento singular descontínuo e ahistórico, voltado para um agora passivel de infinitas transformações. Dentro desse enfoque, desenvolve-se o conceito de "pequena obra", onde através da organização sintática de materiais, experimenta-se a cada instante pequenas verdades; ordens ou desordens provisórias que substituem a grande narrativa da humanidade por histórias do cotidiano, trabalhando no espaço da transformação ao invés da representação.

Em meio à atmosfera de mutação e flexibilidade características da paisagem pública atual, a presença de objetos duráveis expressando permanência/perpetuidade tem dado lugar a manifestações do efêmero e do surpreendente. Nesse contexto sem pontos fixos, a arte e a vida públicas vão refazendo suas texturas continuamente, movimentando, com isso, a própria definição de público, assim como a relação entre público/privado que a sustenta.

Nessa trama, a Arte Pública mostra-se como sendo, ao mesmo tempo, específica e temporária. Não vigora, nesse campo, a ideia de exprimir valores eternos para uma vasta plateia nem a expectativa de se expressar um tema irrepreensivel e acessivel a todos. Irreverente a esses aspectos, a Arte Pública contemporânea 
2 Apud PHILLIPS, PC. Temporality and Public Art. SENIE H.S., Webster S. (eds.), Critical issues in Public Art - content, context, and controversy. New York, Harper-Collins, 1992, p. 297-298.

3 Este debate esteve entre os temas centrais em torno da Arte Pública nos Estados Unidos nos anos 90 e foi extensamente discutido na dissertação de mestrado "Fronteiras do Visivel. Arte Pública na Avenida Paulista. Um estudo-intervenção na cidade de São Paulo", apresentada por esta autora e defendida na ECA/ USP, em 2000.

4 STORR, R. Tilted Arc: Enemy of the people? RAVEN A., Art in the Public interest. London, Ann Albot, UMI Research Press, 1989, p.269 ss. A partir de então, Richard Serra tem desenvolvido seu trabalho principalmente na Europa. frequentemente suscita controvérsias no âmbito de sua recepção, permitindo-se ocorrer e instalar em lugares indiscretos, marginais e não tradicionais.

Filia-se historicamente à escultura ambiental - de grande porte, não devendo, contudo, ser com ela confundida. Em conotações mais recentes, sua denominação como sendo "pública" transcende a estrita referência da obra locada em espaços externos nos quais pode ser amplamente apreendida, atendo-se ao seu modo de acesso ou massa de espectadores. Tem sido definida como uma manifestação de atividades e estratégias artísticas que tornam a ideia de público como gênese e tema de análise. Em outros termos, sua adjetivação tem sido construida sobre sentidos, situações ou conflitos urbanos para os quais se volta, e não em função do seu volume de audiência².

Noções estéticas idealistas que tratam a arte como "linguagem universal", assim como paradigmas que afirmam haver na arte uma "essência estética independente", mostram-se inoperantes no confronto com essa prática urbana. Categorias como autor/ estilo/obra são esmaecidas em suas acepções tradicionais diante do atual panorama da arte contemporânea.

No âmbito da recepção estética, existem aspectos de rejeição e aceitação que monopolizaram o debate público no campo da cultura, como ocorreu no caso de Tilted Arc, de Richard Serra. Comissionada em 1979 pela General Services Administration (GSANY), por US $\$ 175.000,00$, para a New York Federal Plaza. Obra instalada em 1981, foi alvo de hostilidade de certas facções do público urbano, a ponto de culminar na sua remoção do local em 1989². R. Cembalest, em "Public sculpture: race, sex and politics" ${ }^{4}$, referindo-se a uma série de obras relocadas ou removidas definitivamente da esfera pública, focaliza a acidez política, ética e estética dessa dimensão da falência da obra, questionando quem decide se o trabalho deve ser removido. 


\subsection{ARTE PÚBLICA: ESPECIFICIDADE EM RELAÇÃO AO LOCAL DE ORIGEM E SUA LOCALIZAÇÃO NAS MEMÓRIAS COLETIVAS}

A qualificação das relações da Arte Pública com sua situação local está entre os tópicos mais ardentes abordados pela crítica atual, envolvendo diretamente o compromisso ideológico, social e cultural da obra. Precauções são tomadas ante a consideração de "utilidade" da Arte Pública, atentando-se para o viés reducionista no direcionamento da arte para o "preenchimento" de necessidades sociais, configurando-se-Ihe um papel meramente instrumental. Nessa linha, os locais urbanos são abordados de modo funcionalista, tratados, sobretudo fisicamente, preservando-se a dicotomia entre a arte e o social.

Abordando a construção dessa noção de Arte Pública Expandida e sua especificidade em relação a seu lugar, salientase a contribuição da escultura minimalista, nos anos sessenta, como um momento em que os artistas passaram a incorporar no próprio trabalho certas contingências das experiências perceptuais atinentes ao contexto em que este se situa. Mudouse o foco do interior da obra para as condições que a conformam e nas quais se assenta. Tal alteração, porém, embora significativa, ainda configura-se na linha estético-formal, priorizando-se 0 plano físico do ambiente, sem se aproximar das suas condições de produção urbana.

A transformação mais profunda nesse percurso ocorreu mais tarde, quando da passagem desse paradigma formalista para aquele da historicidade, para a qual foram fundamentais os trabalhos em sociologia urbana desenvolvidos em fins da década de sessenta. Abriu-se o caminho para a investigação, na construção da Arte Pública, da "intersecção de dois processos materiais: a produção social do local e a produção social da
5 DEUTSCHE, R. Public Art and its issues. SENIE H., WEBSTER S. (eds). Critical issues in Public Art - content, context, and controversy. Washington: Smithsonian Institute, 1992, p. 297-298 
percepção estética"5. Relações entre as formas espaciais e os processos econômicos e sociais que as moldam passaram a ser destacadas no campo artístico, favorecendo-se a possibilidade de trabalho com a especificidade do lugar da obra como uma prática crítica, articulando as percepções do espaço com percepções históricas, estabelecendo tensões entre espaço e espectador, numa revelação mútua.

Nessa linha de argumentação, a Arte Pública se situa na interface entre a arte e o urbanismo, suscitando a reflexão sobre como ambos se interpenetram. Fomenta-se sua dimensão participativa crítica, a qual contribui para o desenvolvimento da percepção e da reflexão sobre as alterações que ocorrem no urbano, assim como a compreensão do seu papel diante de tais transformações: quais espaços e representações modela ou ajuda a modelar, quais balizas utiliza em sua atuação nesse processo de construção social?

Não é através dos traçados abstratos que essa experiência se estrutura, mas sim, pela experiência com a arte pública, seus monumentos e intervenções; trata-se basicamente de uma experiência estética.

Obras públicas nos auxiliam na compreensão da diferenciação dos espaços, na elaboração de uma fisionomia para a cidade e para nós mesmos como cidadãos.

Se o presente é inimigo da permanência nas cidades contemporâneas, é só através dessa diferenciação de tempo - presente/passado/futuro - que podemos compreender nossa transitoriedade e humanidade.

Através da permanência dos quadros sociais, incluem-se aí a Arte Pública/monumentos como receptáculos de memórias, é que os conteúdos da memória coletiva podem ser elaborados.

Vale lembrar que essa elaboração nada tem de saudosista, pelo contrário, presta-se a iluminar e transformar a experiência do presente e possibilitar os projetos futuros. 


\subsection{ESPECIFICIDADE DO LUGAR DA OBRA COMO PRÁTICA CRÍTICA}

A ideia de site specificity é aqui entendida a partir da noção de esgotamento da forma moderna. Se a escultura moderna absorveu o pedestal para expressar sua indiferença em relação ao lugar, afirmando-se autônoma e auto-referencial, portanto, algo sem lugar fixo, os trabalhos de sítio específico analisados por Miwon Kwon, em sua primeira ocorrência, com o minimalismo, no final dos anos sessenta e início dos anos setenta, forçou uma reversão dramática desse modelo modernista. Segundo Douglas Crimp, o idealismo modernista, no qual o objeto de arte tem um significado fixo e transhistórico, determinou a ausência do lugar do objeto, seu pertencimento a nenhum lugar particular, um nãolugar, o que equivaleria ao museu. 0 site specificity se colocava pela recusa a tal idealismo ${ }^{6}$. 0 espaço ideal dos modernismos foi deslocado pela materialidade da paisagem ou pela ordinariedade do espaço do cotidiano; neste sentido, o espaço da arte passa a se apresentar como um lugar real.

0 paradigma de origem, chamado "fenomenológico", caracterizava-se pela ocorrência primeira da arte de sítio específico, implicando em algo determinado pelas leis da física, a exemplo da frequente noção de gravidade, "presença" e fixidez. Nesse contexto, esta arte tomou o sitio como uma realidade tangivel, cuja identidade era uma combinação única de elementos físicos. Miwon desenvolve uma posição crítica ao apontar que as contradições localizam-se no momento da imobilidade da obra de sítio específico, quer em separação ou assimilação ao lugar ${ }^{7}$, a qual abriu espaço para um contexto rígido e formalmente determinado, tomando como grande exemplo a controvérsia instaurada pela obra de Richard Serra, Tilted Arc, conforme mencionado anteriormente. Além disso, nesta primeira ocorrência do site specificity, o objeto artístico contextualizado deveria ser singular
6 DOUGLAS C. On the Museum's Ruins. Cambridge: MIT Press, 1993. Ver também KRAUSS R. Sculpture in the Expanded Field, Hal Foster, 1979. The Anti-Aesthetic: Essays on Postmodern Culture. Port Townsend, Wash: Bay Press.

7 Rosalyn Deutsche distinguiu entre um modelo assimilativo de site specificity - no qual a obra de arte é ajustada pela integração na paisagem existente, produzindo um espaço de coesão unificado e "harmonioso", e um modelo interruptor no qual a obra de arte funciona como intervenção crítica na ordem existente de um lugar através de algum tipo de fratura. 
8 KWON, M. Genealogy of Site Specificity. In One Place After Another: Site Specificity and the Locational Identity. Cambridge MA, London: The MIT Press, 2002.

9 FRIED M. Art and Objecthood (1967). In BATTCOCK G. (Ed.). Minimal Art: A Critical Anthology. New York: Dutton, 1968

10 KURTZ, B (ed.). Conversation with Robert Smithson. In Nancy H. (ed.). The Wrightings of Robert Smithson. New York: New York University Press, 1979. e multiplamente experienciado no agora através da presença corporal de cada sujeito observador, "na imediata sensorialidade da extensão espacial e da duração temporal"8 (caracterizado ironicamente como teatralidade por Michael Fried) para que o trabalho se completasse 9 . Os imperativos da nova "vanguarda" ligada à atualidade do lugar se relevaram na reestruturação do sujeito, ou seja, na adaptação do antigo modelo cartesiano ao modelo fenomenológico da experiência corporal viva.

0 segundo paradigma - "institucional/social" surgiu com os experimentos estéticos subsequentes dos anos setenta, nas várias formas de critica institucional (land art, process art, installation art, conceptual art, performance/body art). Partindo do contexto minimalista e da arte conceitual, essas críticas desenvolveram modelos de site specificity que desafiavam implicitamente a "inocência" do espaço e a participação presunçosa do ponto de vista universal, ainda que corporal, ao aderir a um modelo fenomenológico, considerando o sitio não somente em termos físicos e espaciais, mas como contexto cultural definido pelas instituições de arte. A crítica institucional insistiu na matriz social do sujeito observador fenomenológico do minimalismo e ao próprio hermetismo idealista do sítio (o espaço moderno da galeria/ museu: sua arquitetura imaculada, rígida, de paredes brancas e luz artificial, permanecera uma convenção normativa servindo como função ideológica em termos espaciais e como pretexto institucional). Tais configurações, aparentemente favoráveis, foram criticadas ao servirem como mecanismos que dissociavam o espaço da arte do espaço da alteridade, promovendo o idealismo imperativo da instituição.

Segundo previu Robert Smithson em 1972, experimenta-se, então, um tipo de ação para expor o confinamento cultural no interior do qual a função dos artistas e o impacto de suas forças sob o significado e valor da arte tornam-se a grande questão para os artistas nos anos setenta ${ }^{10}$. 
À medida que tal investigação se estendeu pelos anos oitenta, fundou-se cada vez menos nos parâmetros físicos da galeria/museu para articular sua crítica. 0 lugar da arte começou a divergir do espaço literal da arte e sua condição física de localização específica retrocedeu como elemento primário na concepção de um lugar; e mais, as técnicas e efeitos da instituição de arte tornaram-se os próprios sítios de intervenção crítica.

Concomitante com o movimento em direção à desmaterialização do lugar tem-se a desestetização e a desmaterialização da própria obra de arte. Indo contra a natureza de hábitos e desejosinstitucionais, e continuando a resistir à comodificação da arte ao mercado, a arte de sítio específico adota estratégias que são ou "agressivamente" antivisuais (informativa, textual, expositiva) ou imateriais (gestos, eventos ou performances agrupados pelas fronteiras temporais). "A 'obra' não pretende mais ser um substantivo/objeto, mas um verbo/ processo, provocando a acuidade crítica do observador (não só fisica), relativamente às condições ideológicas de suas observações" $" 1$.

Se a crítica do confinamento cultural da arte via instituições foi "o problema crucial" das práticas orientadas pelo sítio, segundo Kwon, hoje se debruça na busca de um engajamento mais intenso com o mundo real e o cotidiano, o que corresponde a uma crítica da cultura, inclusive de espaços, instituições e problemas não-artísticos, o que diluiu a divisão entre arte e não-arte. É neste quadro que surge a ideia do terceiro paradigma, o "discursivo". As manifestações recentes de site specificity, preocupadas em integrar a arte mais diretamente com o domínio do social' ${ }^{12}$, seja para restabelecer problemas sociais urgentes (crise ecológica, sem-teto, homofobia, racismo), seja mais genericamente para relativizar a arte como uma entre muitas formas de cultura, tendem a tratar a estética e a história da arte como problemas secundários. Tal expansão de engajamento com a cultura favorecia lugares públicos externos em relação à tradição de confinamento da arte, física e intelectual, própria do modernismo.

11 KWON, M. Genealogy of Site Specificity. In One Place After Another: Site Specificity and the Locational Identity. Cambridge MA, London: The MIT Press, 2002.

12 A ideia é mostrar que, apesar da arte estar imbricada pelo social, muito desse discurso descrito aqui imagina o social como um espaço separado do espaço da arte, até mesmo antitético. 
Os trabalhos contemporâneos de sítio específico ampliaram sua inserção em termos espaciais, ocupando outros lugares, físicos e virtuais; em termos conceituais, informados por um espectro mais amplo de disciplinas; em termos de comunicação de massa, sintonizados mais nitidamente com discursos populares. Para além dessa expansão da arte na cultura, que diversificou a ideia de sítio, a característica que distingue a atual arte de sítio específico é o esgarçamento no modo como se relaciona com a realidade do local e com as condições sociais do quadro institucional, ambas subordinadas a um lugar determinado discursivamente, que é entendido como campo de conhecimento de troca intelectual e debate cultural. Diferentemente dos modelos prévios, esse sitio não é definido como pré-condição; antes, é produzido como "conteúdo" pelo trabalho e depois, verificado por suas convergências com uma formação discursiva existente.

Essas novas práticas refletiram também em questionamentos do próprio sítio específico como um "lugar", interrogando sua ocorrência em relação aos imperativos estéticos, institucionais, sociais, econômicos e políticos. A partir delas, os diferentes debates culturais passam a ser entendidos como sítios, tomando por sítio desde um conceito teórico, uma questão social ou política, um enquadramento institucional (não necessariamente uma instituição de arte), uma condição histórica, até mesmo formações particulares de desejo.

0 sítio é agora estruturado (inter)textualmente mais do que espacialmente; seu modelo transformou-se numa sequência de eventos nômades, articulados pelo artista. Essa orientação corresponderia ao modelo dos espaços eletrônicos da Internet e do cyberspace, estruturados como experiências transitivas (uma coisa depois da outra). Essa transformação do sítio, segundo Miwon Kwon ao mesmo tempo "textualiza espaços e espacializa discursos".

Em práticas artísticas dos últimos trinta anos a definição operacional de sítio foi sendo transformada de uma localidade física 
(fundamentada, fixa, real) para um vetor discursivo (infundado, fluido, virtual). Porém, mesmo que uma formulação particular de site specificity dominasse em um momento e recuasse em outro, essas alternâncias não são definitivas. 0 que significa dizer que, apesar dos três paradigmas de site specificity - fenomenológico, social/institucional e discursivo - terem sido apresentados mais ou menos cronologicamente, eles não são estágios de uma trajetória linear nítida do desenvolvimento histórico, e sim definições superpostas que operam simultaneamente em várias práticas culturais atuais. 



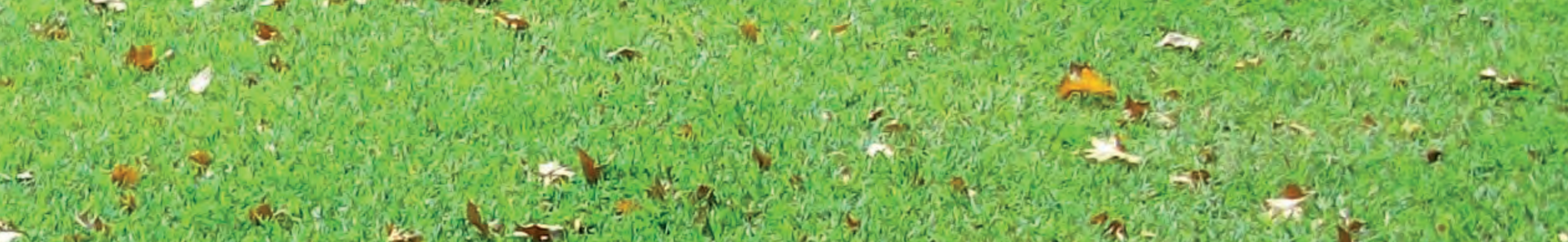

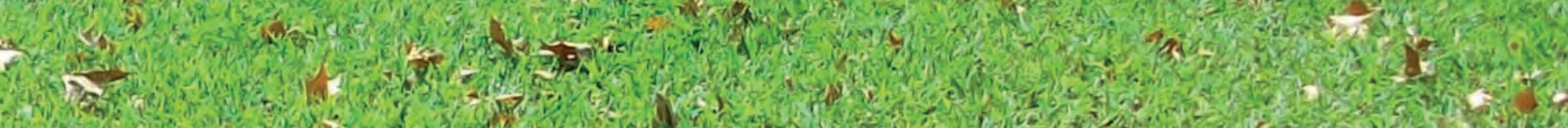

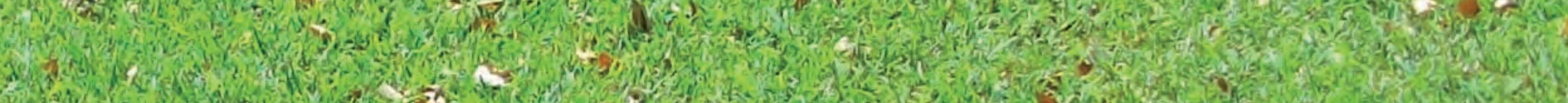

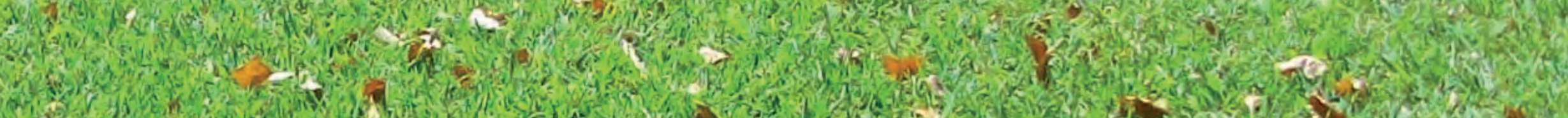

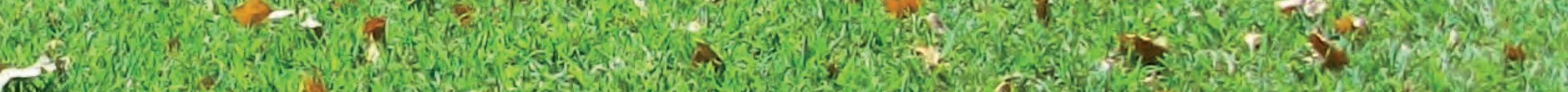

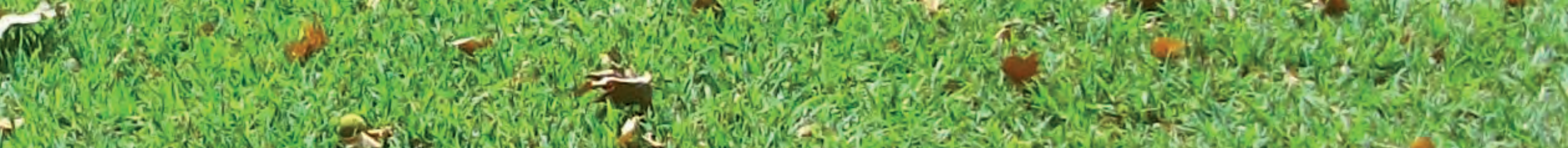

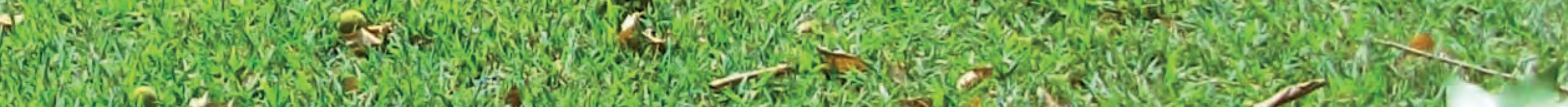
2.6.6. a.t.

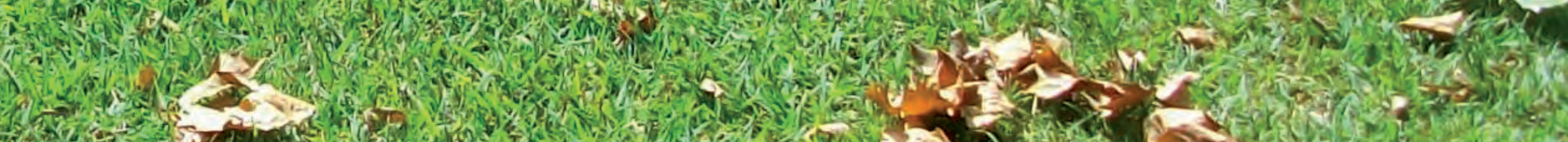
7. $7 x^{2}$ 17. 1.2 7 . 20.

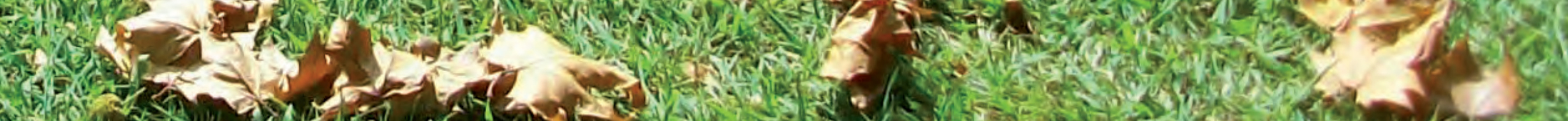
1.

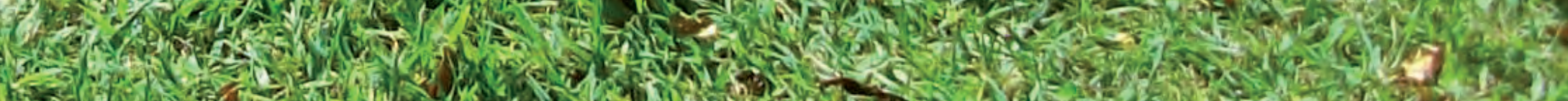

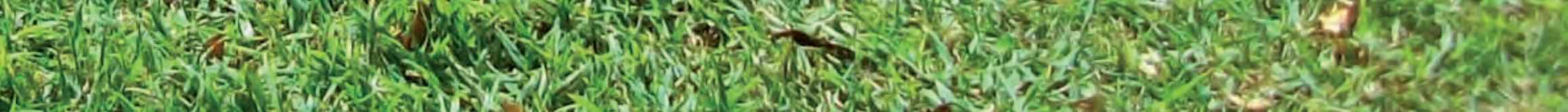


min

|

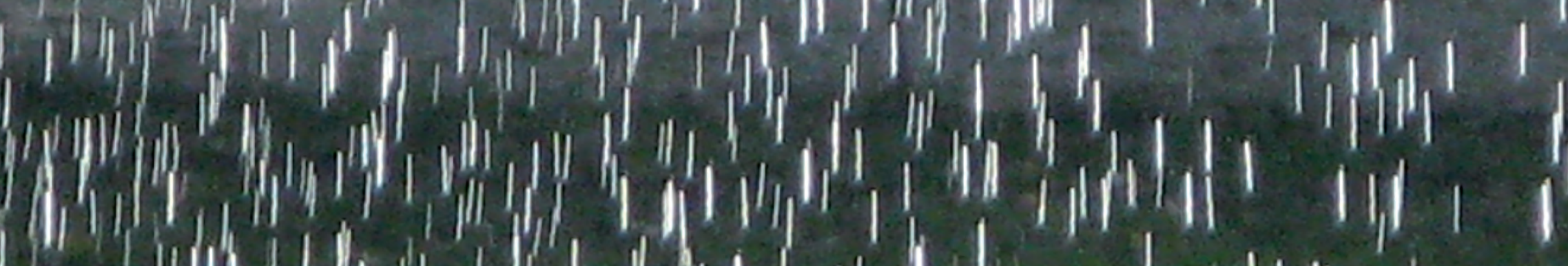

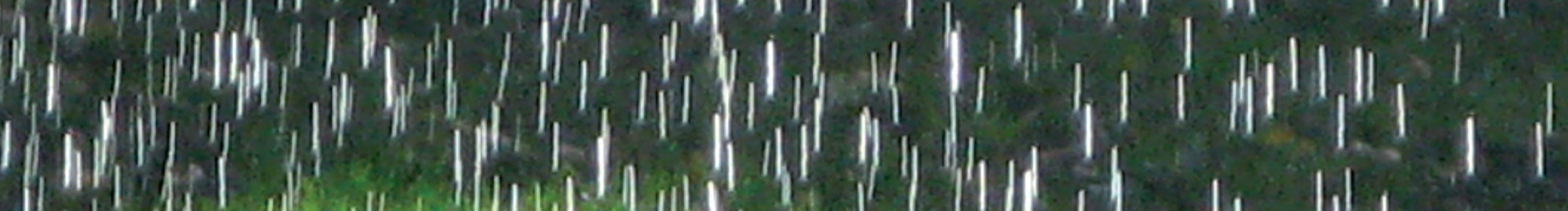

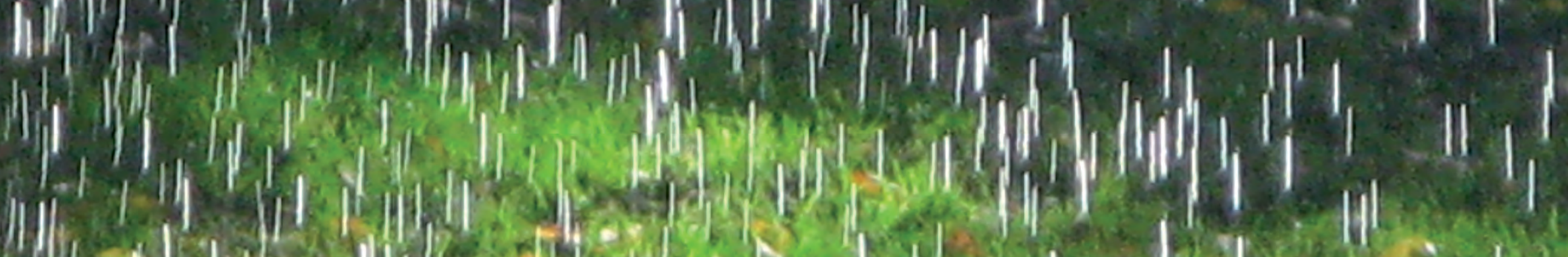
Hin 4 - 14 .

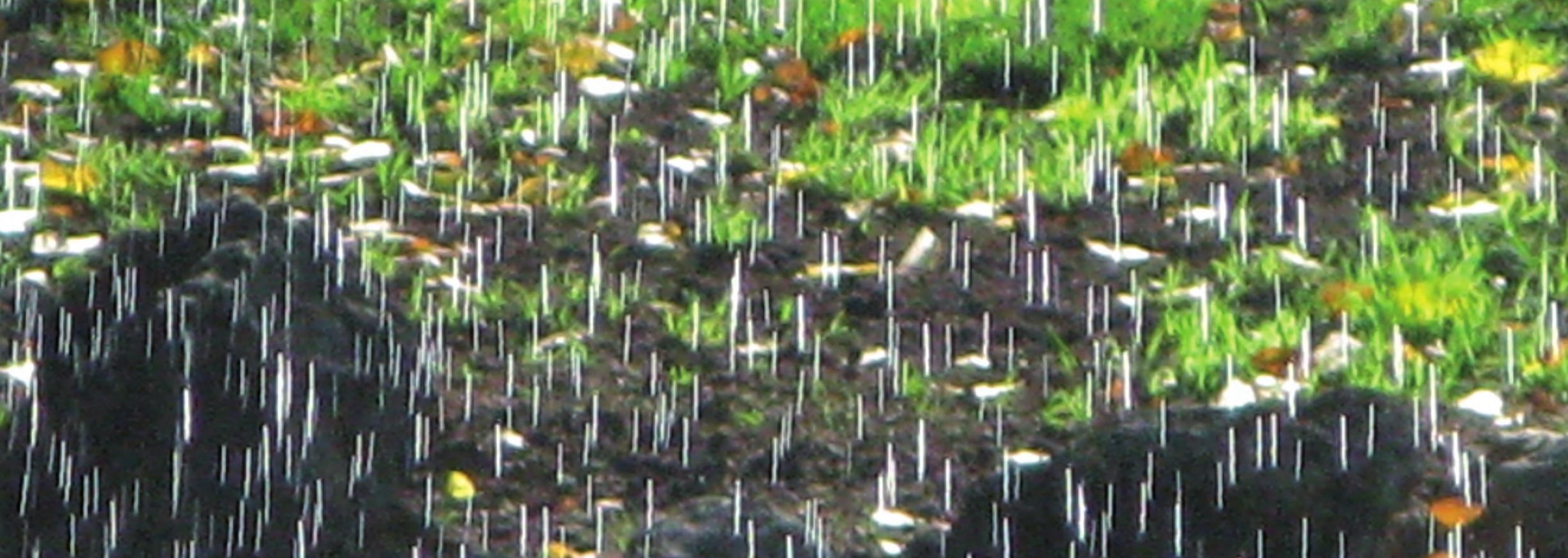




\section{LIMITES DIFUSOS; DesI oc a mentos e Impl ic a ÇÕes da Arte PÚbl ic a Cont empor Ânea}

\subsection{ARTE PÚBLICA E COMUNIDADE: ORIGENS E EVOLUÇÃO DAS PRÁTICAS ARTÍSTICAS COLABORATIVAS}

Grande parte das práticas atuais relacionadas com a arte pública associa-se ao termo arte comunitária ou arte da comunidade, tradução do termo em inglês community art. Em uma genealogia da arte pública, a arte comunitária seria a origem do "novo gênero de arte pública/new genre public art" (LACY, 1995) e em geral o que podemos denominar arte pública crítica e práticas artísticas colaborativas.

Pretendemos analisar o significado e a evolução da arte comunitária, cujas mutações ocorrem especialmente nos Estados Unidos e na Inglaterra, considerando ser esta uma parte essencial da reconfiguração da arte pública contemporânea e, portanto, uma referência ideológica, metodológica e ética imprescindivel 
para a documentação e a análise crítica do panorama atual neste campo da produção artística, que tem estado presente e aquecido os debates em torno das práticas contemporâneas.

Uma ausência, em nosso contexto, de uma tradição similar à da arte comunitária não é obstáculo para que seja cada vez mais comum falar de "comunidades" no âmbito artístico, como também no educativo ou no museístico, para descrever práticas que implicam na participação, na relação e na educação com o contexto social ou a atenção das instituições para a diversidade cultural do entorno.

Não é fácil definir o termo arte comunitária. Dependendo do momento histórico ou do lugar podemos encontrar matizes em seu significado transformado ao longo do tempo pela sociedade e a arte, desde finais dos anos sessenta até a atualidade. Arte comunitária pode ser o nome que recebe um programa municipal de apoio ao ensino das artes como meio para o desenvolvimento cultural, pode fazer referência a um projeto de arte pública que implique na colaboração e na participação ou, ainda, equiparar-se em alguns casos à animação sociocultural. Pode ser promovido institucionalmente, por um coletivo de artistas ou por uma associação cultural, envolver as artes plásticas, mas também o teatro, a dança, o artesanato, as festas tradicionais. Alguns autores apostam, ante esta diversificação, em termos como Community Cultural Development, "desenvolvimento cultural comunitário" (ADAMS; GOLDBAR, 2001), ou Art Based Community Development "desenvolvimento comunitário baseado na arte" (CLEVELAND, 2002).

Nas palavras de Sally Morgan, pioneira da arte comunitária na Inglaterra: "se a arte comunitária é algo, é a manifestação de uma ideologia" (MORGAN, 1995:18). Uma ideologia que poderiamos descrever como confiança na relevância social da arte e na possibilidade de uma cultura mais acessivel, participativa, descentralizada e que reflita as necessidades e particularidades 
das diferentes comunidades. 0 que todos estes enfoquem têm em comum é a convicção de que a criatividade possui uma força real de transformação social. Todos os artistas comunitários, segundo a autora, compartilham de uma discordância em relação às hierarquias culturais, uma crença na co-autoria da obra e no potencial criativo de todos os setores da sociedade.

Em relação à Arte Pública, o termo arte comunitária se associa a certos tipos de práticas que buscam um envolvimento com o contexto social e, para além das qualidades estéticas, busca, sobretudo, um benefício ou melhora social que engaja a colaboração e a participação das comunidades envolvidas na realização da obra. Estas práticas implicam uma revisão dos conceitos modernistas de artista e de obra de arte. 0 artista delega parte de suas funções tradicionais ao grupo e o conceito de obra artística se transforma por seu caráter processual e de intervenção social. Devido ao caráter colaborativo, contextual e social destas práticas podemos encontrar também outras expressões que estabelecem conexões com a arte comunitária como são arte contextual (ARDENNE, 2006), arte dialógica (KESTER, 2004) ou arte relacional (BOURRIAUD, 2007) e, evidentemente, o novo gênero de arte pública (LACY, 1995).

\subsection{CONTEXTO SOCIAL DA ARTE E PARTICIPAÇÃO: OLHANDO EM DIREÇÃO AOS ANOS SETENTA}

Se queremos investigar as raizes da arte comunitária em relação à arte pública devemos voltar o olhar aos anos sessenta e princípio dos setenta. Há ideias chave para compreender a evolução de novas formas de arte, por exemplo, a ideia de que o significado da arte deve encontrar-se no contexto físico ou social, 
e não no do objeto autônomo e o novo interesse pelo público e pelas formas de envolvê-lo na obra. No efervescente ambiente artístico e cultural dessa década encontramos uma linha artística marcada pela evolução das práticas conceituais, performativas e da arte de ação até o ativismo sociopolítico (FELSHIN, 2001).

0 questionamento tanto da arte pela arte, como dos valores do formalismo, ou do sistema do mercado artístico, propiciou uma deriva da ideia da obra de arte como ferramenta de mudança social. A crítica ao individualismo como eixo do processo criativo e do artista como criador isolado e genial favoreceu que um número importante de artistas renunciasse a seu status e trocasse o marco de elitismo cultural por uma vinculação de seu trabalho com problemáticas do contexto social, normalmente relacionadas a grupos sociais desfavorecidos e suas necessidades. Esta importância pelo contexto levou ao deslocamento da obra da galeria e do museu para situá-la em âmbitos mais cotidianos. Nas palavras de Davis Harding, um dos mais influentes artistas comunitários da Inglaterra "individualismo, autoexpressão e arte pela arte, começam a ser recolocadas por colaboração, relevância social, processo e contexto" (HARDING, 1995).

Um exemplo relevante destas ideias no âmbito britânico é o trabalho do Artist Placement Group, que Harding cita como referência muito importante de seu trabalho e de toda a evolução da arte pública e comunitária em seu país. Com seu lema: "The context is half the work", este grupo, criado em 1965 e liderado por John Latham e Barbara Stevini, propiciou novas formas de conceber a arte fora do mundo das galerías e dos museus, desenvolvendo uma forma de trabalho para posicionar artistas a realizarem suas obras em contextos cotidianos, em situações não artísticas, dentro de diversas instituições governamentais e privadas. Os artistas se situavam como observadores e participantes diretos das atividades de organismos como o London Health Department, o Department of Environment of Birmingham ou a Scottish Office de Edimburgo. 
Em colaboração com seus trabalhadores, alguns artistas produziram projetos com esculturas, vídeos participativos, performances ou estudos do processo de tomada de decisões na dinâmica interna da empresa. 0 objetivo era experimentar de que maneira o pensamento do artista, mais imaginativo e a longo prazo e com maior capacidade para conectar campos e disciplinas, podia influir na resolução de problemas. A ideia frutificou com relativo êxito, e em função disso, o British Council Service, em 1972, estimulou as agências governamentais a envolver artistas no planejamento de suas atividades. Posteriormente, a ideia foi assumida pelo Arts Council, e se transformaria em uma versão menos arriscada tomando a forma do artist in residence (HARDING, 1995).

$\mathrm{Na}$ direção do que poderíamos chamar de tendência contextual da arte, encontramos também nestes anos a intenção por desenvolver novas formas de envolvimento e participação do espectador na obra. Artistas como Allan Kaprow, Vito Acconci, Adrian Piper ou Mierle Laderman Ukeles, com seus happenings, vídeos e performances, elaboram uma série de obras que buscam o que poderíamos denominar, de acordo com Kester (2004), uma relação mais "dialógica" com o espectador, superando a relação tradicional obra-observador e estabelecendo uma interação, um diálogo necessário para completar a obra. Muitas dessas obras já propõem, no final dos anos sessenta, uma relação colaborativa entre artista e público ou instituições locais (BISHOP, 2006).

No âmbito da arte pública, o interesse pelo contexto amplia a ideia da obra site specific, quer dizer, obras realizadas para uma localização concreta que deverão levar em conta as características espaciais e físicas do lugar. A ideia irá se ampliando para a consideração do contexto como espaço humano e social, não unicamente físico. Entretanto, a crescente sensibilização com o tema da arte pública e a preocupação pela audiência chega às mesmas instituições artísticas que entendem que o artista deve contar com a comunidade de uma maneira mais efetiva. As 
diretrizes dadas pela National Endowment for the Arts nos Estados Unidos para os programas de arte pública, sobretudo a partir do debate e polêmica suscitada com o caso da obra de Richard Serra Tilted Arc (CANDELA, 2007; KWON, 2004; FINKELPEARL, 2001) assim o promovem. Como descreve Finkelpearl (2001), as indicações da NEA variaram nesses anos desde a consideração de que a obra devia ser "apropriada para o lugar" no ano de 74, à necessidade de "informar ao público" no ano de 79 e a partir daí a participação comunitária significaria a inclusão de representantes não artísticos da comunidade nas comissões e comitês de seleção e revisão das obras de arte pública. Aos finais dos anos oitenta se desenvolveria um diálogo entre o artista e sua audiência buscando possibilidades de participação, inclusive, na realização da obra.

\subsection{A ARTE NO CONTEXTO URBANO: POR UMA CULTURA DO DIÁLOGO}

Dentro do panorama apontado, um dos exemplos mais significativos como origem da arte comunitária nos Estados Unidos - desenvolvido no espaço público em colaboração entre artistas e comunidades locais - são os murais que começaram a ser elaborados nos finais dos anos sessenta e primeiros anos da década de setenta. Os trabalhos se realizaram normalmente nos guetos de comunidades latinas e afroamericanas das grandes cidades de todo o país, bairros que sofriam, em sua maioria, sérios problemas de pobreza, dificuldade de adaptação e racismo.

Tais práticas pretendiam responder a umas pautas semelhantes: normalmente um artista da vizinhança, conhecedor dos problemas do entorno e com forte compromisso social se envolve na realização de uma obra/pintura que reflita os problemas, histórias ou desejos 
de sua comunidade e cuja realização implica uma participação das pessoas do bairro.

Barnett (1984) nos informa que esses artistas estavam longe de se considerar membros da uma elite cultural e se viam mais como "trabalhadores culturais", termo utilizado pelos artistas próximos aos movimentos de esquerda dos anos trinta.

Um dos exemplos mais conhecidos é o The Great Wall, o mural coordenado pela artista Judy Baca em Los Angeles, ao longo do canal de controle da corrente do rio Los Angeles, que começou no ano de 76 e continua em processo, desenvolvido por centenas de adolescentes de distintas origens culturais. Colaboraram com o projeto políticos locais, engenheiros, professores, antropólogos, grupos de adolescentes, entre outros, e que pretende refletir a História não branca de Los Angeles, representando as lutas e as contribuições da população indigena, as minorias imigrantes e as mulheres, desde a pré- história até os anos cinquenta.

Judy Baca foi diretora durante vários anos do Citywide Murals, um centro em Los Angeles encarregado de promover e coordenar a realização destes murais comunitários. A artista assim descreve o processo que supervisionava quando esteve nesse cargo (citada por BARNETT, 1984):

começa quando recebemos um telefonema de um professor, de um artista local, ou inclusive de um membro de um grupo local que nos indica que existe um interesse por realizar um mural e que desejam organizar uma equipe para desenvolver o trabalho. Normalmente o artista indicado apresenta seus estudos em uma reunião com o grupo. Os residentes comumente fazem sugestões em relação à temática e o artista vai incorporando as modificações sugeridas em seu projeto. Cópias dos estudos são exibidos nos espaços públicos para que as pessoas tenham a possibilidade de pensar neles e propor alterações. A elaboração costuma envolver a colaboração de diferentes grupos de pessoas do bairro. 
Como aponta Lucy Lippard (1998), o trabalho realizado por esses muralistas ativistas, pioneiros de um conceito democrático de cultura, tem sido dificilmente reconhecido pelo mundo artístico. Para Marshall Berman (1982), em seu estudo sobre o desenvolvimento da Modernidade no século XX, o mural de Judy Baca se reporta ao melhor da tradição modernista que buscava recuperar a vida urbana a partir da mescla, da diversidade, do contato com o outro, com a diferença, a partir de construir definitivamente, uma "cultura do diálogo". Observa também como mostra de um dos temas centrais da cultura dos anos setenta nos Estados Unidos: a reabilitação da memória e a história étnica como parte vital da identidade pessoal. Já não se tenta construir um presente aniquilando o passado, mas por meio da recordação.

Entre os trabalhos de referência nos primeiros anos da década de setenta no campo da arte pública, no contexto comunitário, situam-se, também, as práticas de arte feminista, como o projeto do ano de 1972 Womanhouse, do Feminist Art Program do California Institute of the Arts, no qual Miriam Saphiro e Judy Chicago, juntamente com um grupo de estudantes transformaram uma velha casa em uma complexa instalação que refletia os sonhos e os temores das mulheres. Ou como The Dinner Party, também de Judy Chicago, na qual convidou centenas de mulheres a participar de todo o processo de criação da obra entre 1974-78.

Enquanto a arte comunitária, e sua derivação no novo gênero de arte pública, gerou um corpo considerável de textos críticos nos Estados Unidos, não se observou o mesmo na Inglaterra ou no Brasil no mesmo período, sendo, por esta possível razão, menos conhecida a evolução da arte comunitária e pública nestes países, resultando em profundas lacunas e até certo preconceito.

O Reino Unido, nos anos setenta, enfrentou um período difícil nos âmbitos econômico e social, apresentando altas taxas de desemprego, situação que levou muitos artistas desencantados com o sistema das artes a buscar uma relevância social para 
seu trabalho. As origens da arte comunitária na Inglaterra se associam ao desenvolvimento das New Towns. Por este nome se conhecem as novas cidades desenvolvidas após a II Guerra Mundial para descongestionar a população das grandes cidades e atender às necessidades de novas zonas residenciais para a classe trabalhadora. Recorrendo à ideia da cidade jardim, cuidando

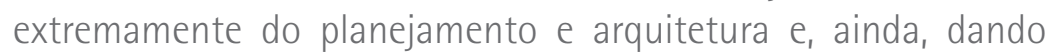
grande importância à integração entre arquitetura e natureza, o desenvolvimento nessas new towns incluiu a participação cidadã como metodologia básica no planejamento urbano. A maioria dessas novas cidades incorporou um grande número de obras de arte no espaço público.

Mas além dessa atenção para a arte nas ruas, este desenvolvimento foi visto por algumas pessoas como a oportunidade de realizar experiências e ideias mais inovadoras com relação ao urbanismo, como por exemplo, a integração dos artistas na criação dos novos espaços públicos, trabalhando em consonância com os arquitetos, urbanistas e engenheiros. 0 caso mais conhecido é o da cidade de Peterlee e o trabalho nela realizado pelo pintor Victor Pasmore (HARDING, 1995). Seguramente David Harding é o artista mais conhecido nas new tonws pelo seu trabalho em Glenrothes, na Escócia, no início dos anos setenta. Foi o primeiro artista a ser contratado durante anos para trabalhar como "town artist", termo criado exclusivamente para definir seu trabalho, inexistente até o momento (HARDING, 1995). 0 artista escocês trabalhou como mais um membro do departamento de planejamento urbano, junto com arquitetos, urbanistas e designers, colaborando em todas as fases do desenvolvimento urbanístico da nova cidade de Glenrothes. A contribuição pessoal de Harding, diferentemente de Pasmore, foi a de envolver os moradores na criação das obras de arte. Seu trabalho, neste sentido, consistiu fundamentalmente na realização de obras colaborativas, realizadas com grupos de 
estudantes e também de adultos, que participaram da elaboração de pinturas murais, murais cerâmicos e esculturas nos espaços públicos. Realizou mais de 250 trabalhos durante esse período.

Estabelecendo relações entre os trabalhos do artista britânico e os muralistas americanos, pode-se dizer que entre os principais objetivos subjacentes às práticas colaborativas a ambos os processos estava a melhoria dos espaços públicos onde vivia a classe trabalhadora - promovida pelos próprios moradores agentes ativos na transformação desse entorno. Esta tendência criou uma esteira de trabalhos de arte pública ativista que tratou de reagir às transformações urbanas e a seu impacto na cultura e na identidade das comunidades.

Harding assinala como uma de suas ideias iniciais a de desenvolver um sentido de lugar naquelas cidades sem referências simbólicas, criadas a partir de uma tabula rasa. Ele o fez melhorando a identificação dos cidadãos com esses entornos residenciais, ao criar pequenos marcos visuais altamente significativos para os moradores, devido ao seu envolvimento criativo. Neste trabalho o artista estava muito consciente do potencial da arte como elemento transformador e como meio de inclusão social, concretamente com jovens excluidos do sistema educativo. Apesar de reconhecer a dificuldade para medir os efeitos benéficos destas práticas, Harding comenta que "para os artistas o idealismo e a convicção sobre o papel da arte como ferramenta dramática e transformadora para a mudança das vidas das pessoas já era suficiente para levá-la adiante" (HARDING, 2006:137).

Não é possível, portanto, separar as práticas de arte pública de uma intencionalidade fortemente educativa em seu sentido emancipatório e de instrumento para o desenvolvimento humano. Para alguns autores, esta seria uma caracteristica essencial da arte pública em sua ambição política e cultural em longo prazo. Existe uma esperança nas possibilidades formativas da arte e da criatividade, assim como na capacidade para gerar uma transformação social 
e cultural. É notória, na Inglaterra, a influência de nomes como Herbert Read na busca de valores democráticos e de liberdade através da arte. Mas sobretudo, é muito importante a influência da pedagogia crítica, de Paulo Freire e de suas ideias sobre o diálogo como referência de aprendizagem bidirecional, neste caso artistacomunidade, comunidade-artista, e sobre o poder da educação e da cultura para mudar a vida das pessoas.

\subsection{TRANSFORMAÇÕES DA ARTE PÚBLICA NOS ÂMBITOS EDUCATIVO E INSTITUCIONAL}

Nos anos setenta, a arte pública/arte comunitária foi vista em seu início como movimento radical, alheia ao interesse da crítica de arte e das instituições. Com o tempo alcançou status muito diferente, ao ser assumida como instrumento de política social e ao ser tomada como objeto de ensino em centros de arte. Como informa Crickmay (2003), existiu por parte de muitos artistas uma resistência à institucionalização e burocratização destes projetos.

$\mathrm{Na}$ Inglaterra se produziu de forma mais fluida que nos Estados Unidos o deslocamento destas práticas para o ensino. Um dos primeiros cursos a apresentar como conteúdo a arte pública, arte comunitária ou o ativismo social foi "Art and Social Context", uma titulação de três anos, iniciada em 1977 por Paul Olivier no Dartington College of Arts, em Devon. Segundo Crickmay, diretor entre os anos de 1978 a 1991, o curso foi idealizado com a intenção de formar artistas "capazes de responder aos imprevisiveis desafios criativos que ocorrem no contexto comunitário" (CRICKMAY, 2003). 0 conteúdo do curso nos primeiros anos girava em torno de aspectos processuais da arte, os métodos de trabalho colaborativo, a dimensão ecológica e ambiental da arte, o desenvolvimento de projetos comunitários e os métodos de análise da imagem baseados 
na semiótica e na antropologia. Inspirado diretamente no trabalho de Artist Placement Group, o programa incluia práticas para estudantes que deveriam selecionar um entorno distante da prática artística e elaborar um projeto que preferencialmente envolvesse a participação de pessoas que vivessem ou trabalhassem no lugar. Com esta intenção desenvolveram-se projetos em lugares tão dispares e cotidianos como uma lavanderia, grandes armazéns, pontos de ônibus, um restaurante fast food, associações jovens, centros para pessoas com necessidades especiais, um ginásio, uma igreja, uma estação de trem, um parque infantil etc.

Segundo Crickmay, a essência desse trabalho era trabalhar sem uma ideia prévia do projeto, sem requisitos a priori, propiciando que este emergisse do contato com o lugar e com as pessoas. Trata-se de um modelo de prática artística baseada em "escutar" (listening model), em conectar com o contexto de uma forma aberta e respeitosa.

Com o passar do tempo, desde o início dos anos setenta, as transformações das políticas artísticas inglesas têm propiciado uma reconfiguração dessas ideias através de sua absorção institucional, convertendo-se em uma parte integral da política cultural oficial. Instituições como o Arts Council, que a partir do ano de 74 impulsionou um programa de suporte econômico para a arte comunitária, e muitas outras públicas e privadas subvencionam um grande número de projetos centrados na comunidade, normalmente em relação a setores desfavorecidos socialmente ou em situação de risco: idosos, jovens, desempregados, minorias étnicas, pessoas com necessidades especiais etc.

Também galerias de arte (a Whitechapel ou a Serpentine em Londres, entre as mais conhecidas), museus ou centros de arte mantém uma ativa política educativa neste sentido. Sob a figura do artista residente, escolas, hospitais e muitos outros locais comunitários têm sido absorvidos dentro das competências das políticas artísticas do setor público. Alguns dos efeitos adversos 
desta assunção institucional tem sido a pressão para que os fundos empregados apresentem resultados em projetos em curto prazo, pervertendo, assim, a tendência "natural" da arte pública de trabalhar projetos em períodos mais dilatados que impliquem em verdadeiro desenvolvimento educativo e cultural. Os artistas também criaram suas próprias associações, sendo a mais importante nos primeiros anos a ACA: Association of Community Artist. Conforme informa Morgan (1995:16):

(...) a arte comunitária não nasceu completamente definida. Cresceu gradualmente, através de um ensaio e erro, através dos esforços de artistas e comunidades. Foi um movimento empírico: provando, valorando, recusando e adaptando.

A partir dos anos oitenta, estudos com relação a práticas contextuais e comunitárias foram se expandindo pelo Reino Unido e também para países como França e Alemanha. Um exemplo de estudos atuais aplicados especificamente à arte pública entendida como desenvolvimento cultural pode ser o Community Arts Degree, que se oferece desde o ano de 1989 na Universidade de Strathclyde, na Escócia. 0 seu objetivo é formar pessoas para envolver ativamente indivíduos, grupos ou comunidades nas artes, para que tenham a possibilidade de 'melhorar sua autoestima, construir sua identidade e encontrar formas para desenvolver uma mudança do "ponto de vista pessoal, social, cultural ou político"' (AUSTIN, 2008:176).

Assim mesmo, tem-se desenvolvido uma forte relação entre a arte comunitária com a arte pública e o desenho urbano em experiências para a revitalização de espaços públicos como dinâmica de melhoria ambiental, mas também de transformação e inclusão social das pessoas envolvidas. É possível encontrar um grande número de casos desse tipo que são geridos por autoridades locais (culturais, artísticas, comerciais etc.) tanto públicas como 
privadas e que desenvolvem propostas de trabalho colaborativo entre residentes do lugar, escolas, artistas, associações de bairro, arquitetos e outros.

Dentre as demais localidades da Europa, a Finlândia seria um bom exemplo de país que tem desenvolvido uma sólida concepção social e contextual de arte e arte educação através de práticas comunitárias, em um terreno em que se une à arte pública ao estar conectada, em grande parte, com o trabalho junto ao meio ambiente em seu sentido mais amplo: físico, mas também social e cultural (COUTTS; JOKELA, 2008).

No caso americano, encontramos um percurso similar ao britânico, com grande número de instituições dedicadas ao financiamento de projetos de arte comunitária a partir dos anos setenta. Uma das que mais contribuiu em sua extensão foi a CETA Department of Labor's Comprehensive Employment and Trainning Act, que sendo uma organização de emprego e formação profissional envolveu um grande número de artistas em locais diferentes como hospitais, prisões, asilos etc., convertendo-se no "maior programa federal de arte da história" (CLEVELAND, 2002).

Os anos noventa são testemunha de um interesse renovado pelo financiamento de assuntos comunitários, ao ponto dos limites entre arte e política social se tornarem difusos. Segundo Kester (2004) para compreender completamente a arte comunitária nos Estados Unidos é necessário considerar a história da assistência social e em geral, das políticas assistenciais neste país. Conceitos como empowerment ou "democracia participativa" emergem na retórica da arte comunitária provenientes do âmbito de programas como o do National Welfore Rights Movements durante os anos sessenta. Para Kester, a figura do artista comunitário propiciada pelas políticas governamentais nos anos noventa poderia ser comparada à do trabalhador social e, inclusive, a de um "evangelizador estético", devido à leitura do modelo de pedagogia moral que realizou o neoliberalismo nessa década (KESTER, 2004). 
Entre finais dos anos oitenta e princípios dos noventa, produziuse uma convergência entre a tradição da arte comunitária e as novas ideias sobre arte pública, menos implicadas na produção de objetos e mais com o desenvolvimento de novas formas para o envolvimento do público. A recepção é inerente à arte pública e a formação do público é o método e objetivo; a intenção geral e o resultado final. Contribuições teóricas como as de Suzanne Lacy em Mapping the Terrain: New Genre Public Art ou de Nina Felshin em But is it Art? The Spirit of art as Activism, ambas do ano de 95, ou o certame organizado por Mary Jane Jacob Culture in Action: New Public Art in Chicago, em 1993, marcaram as diretrizes para a década seguinte. Artistas como a própria Suzanne Lacy, Mangano Ovale, Loraine Lesson e Peter Dunn, ou coletivos como Wochenclause ou o Group Material, tem expandido o campo da arte pública nos últimos anos mantendo o espírito ativista dos primeiros, mas desenvolvendo projetos com um maior caráter processual e em muitos casos, tornando difusos os limites entre arte e ação social.

\subsection{QUESTIONAMENTOS: DILEMAS E TENSÕES PRESENTES NAS PRÁTICAS COLABORATIVAS CONTEMPORÂNEAS}

São diferentes os âmbitos das práticas comunitárias: galerias, hospitais, centros culturais, associações cidadãs etc. Alguns contextos mais distantes do sistema institucional da arte, em relação com as políticas sociais e culturais das instituições locais ou com as iniciativas de artistas e coletivos ou associações; e outros na órbita da arte pública, que sucedem em estruturas próprias do sistema de arte, dentro da engrenagem de festivais, projetos conduzidos por artistas mais ou menos conhecidos e que se 
movem em um campo de maior notoriedade crítica. Os primeiros, mais centrados em aspectos educativos, de ativismo sociopolítico e de bem-estar social e menos sujeitos a considerações estéticas ou críticas. Os segundos, mais condicionados pelas complexas interações artista-curador-instituição cultural-comunidade. Estes contextos são passiveis de se entrecruzar cada vez mais e as fronteiras entre arte pública, arte comunitária, educação e intervenção social tendem a ser menos visiveis.

Seja num ou noutro terreno, a arte pública tem estado rodeada de polêmica pelos debates que tem gerado tanto do ponto de vista estético quanto ético e político. Um dos principais problemas é, precisamente, a própria definição e delimitação do conceito de comunidade (KWON, 2001; KESTER, 2004). Em sua concepção mais simples engloba um grupo de pessoas unidas por um mesmo vínculo, experiências, histórias ou interesses comuns, normalmente definidos por oposição à cultura dominante. Trata-se comumente de coletivos desfavorecidos, marginalizados de alguma forma ou simplesmente com necessidade de deixar ouvir sua voz.

Atualmente, a comunidade se converteu em lugar no qual se intervém artisticamente. Neste sentido, quando Ramon Parramon fala, em relação aos projetos de Idensitat, de comunidade como "possivel território para desenvolvimento de experiências artísticas", entende que um território é um espaço físico, mas também um conjunto de relações humanas e sociais (PARRAMON, 2008:14).

Mwon Kwon (2004) descreveu quatro tipos de comunidades, em função das relações que estabelece com um projeto de intervenção artística:

- A comunidade entendida como uma categoria sociali, por exemplo, as mulheres, os imigrantes latinoamericanos etc. Trata-se de um conceito, que por sua generalidade implica necessariamente um alto grau de abstração em relação à identidade. Para Kwon, não deixa de ser uma "mitificação" que deixa de lado as particularidades e experiências individuais. 
- A comunidade entendida como um grupo ou organização instalada no lugar, como por exemplo, o grupo de trabalhadores de uma fábrica, uma associação de imigrantes de bairro ou o alunado de um instituto. Estes grupos vêm definidos pelo projeto artístico; o artista especifica a necessidade de trabalhar com esta ou aquela organização ou grupo da localidade. Comumente são os organizadores da convocatória artística os encarregados de mediar, facilitando o contato com o grupo. A comunidade se cria para a realização da obra, como no caso anterior, mas continua depois do projeto como entidade autônoma e independente. Neste caso, o artista deve ter bastante contato com o grupo ou residir no lugar, pelo que o projeto se beneficia da relação direta e contínua do artista local. Um exemplo de comunidade consolidada pode ser o projeto de Manglano Ovalle para Street Level Video Media, criado no contexto do projeto Culture in Action, curado por Mary Jane Jacob em Chicago.

Não obstante o maior problema com relação à comunidade perpasse todos estes modelos, aparece com a consideração da comunidade como um conceito estável. Como aponta Jean Luc Nancy (1991), citado por Kester (2004), nossas identidades estão sempre em negociação, sempre em processo de ser formadas e reformadas através do encontro com os outros; assim, uma comunidade que não seja essencialista, se produz, precisamente, "através do conhecimento de que não temos uma substancial identidade".

Portanto, a grande dúvida é a existência de um sujeito coletivo único detrás da comunidade. 0 que é e o que realmente une os membros de uma comunidade? Que características definem o grupo? Até que ponto não se projeta determinados estereótipos para definir ou nomear uma comunidade?

Este questionamento implica em fortes repercussões nos projetos 
artísticosquebuscamo envolvimento comunitário. Uma compreensão equivocada das identidades, histórias, relações territoriais e sociais do grupo com o qual se pretende trabalhar pode levar à simplificação e ao engano, à manipulação ou à instrumentalização de determinados coletivos, tanto por parte do artista como das instituições públicas ou privadas que apoiam, organizam ou financiam os projetos. Há exemplos de projetos "falidos" em relação às confusões geradas na consideração da identidade da comunidade envolvida. Nem sequer é uma garantia de êxito o fato de o artista fazer parte da comunidade, como atesta o caso de John Ahearn e seu trabalho na Praça de Bronx (FINKELPEARL, 2001).

Diante destes questionamentos, uma autora como Mwon Kwon (2001) mostra-se muito cética e questiona qualquer comunidade que se defina com base em uma identidade comum. Kester, entretanto, propõe o conceito de "comunidade politicamente coerente", que surge como:

(...) resultado de um processo complexo de autodefinição política. Processo desenvolvido contra algum modo de opressão (crença religiosa, raça, sexo, classe social (...) mas também dentro de um contexto cultural compartilhado e com uma tradição discursiva (KESTER, 2004:150).

Este tipo de comunidade tem mais possibilidades de constituirse em um interlocutor sólido para o artista e garantir, desta maneira, um projeto artístico construido sobre um diálogo bidirecional real e sem incompreensões, mistificações ou instrumentalização.

Outra frente de debates aborda os questionamentos estéticos associados às obras comunitárias, desde o desinteresse por parte da crítica de arte tradicional em relação a estes tipos de práticas, as quais poderíamos chamar de um "descrédito do participativo", até as dúvidas que se apresentam ao qualificar como artísticos projetos que podem resultar indistinguiveis do ativismo político ou social. 
Neste sentido, Kester (2004) aponta que faltam recursos na teoria moderna de arte para a análise destes projetos, nos quais a ruptura com os esquemas significativos e comunicativos da arte de vanguarda torna necessário o desenvolvimento de critérios de avaliação e análise apropriados a esta nova especificidade.

Um dos critérios deveria ocupar-se dos possiveis aspectos estéticos, por exemplo, estudando os aspectos visuais, sensoriais ou espaciais destes tipos de projetos, ainda que não sejam obras objetuais, ou considerando as transformações que estes tipos de projetos trazem consigo na percepção de uma problemática social ou de estereótipos comunitários, como novas modalidades da experiência estética.

Não somente torna-se necessário o desenvolvimento de um marco teórico-crítico, mas também um estudo dos benefícios que as práticas colaborativas apresentam para a sociedade. Se o que se pretende com estes projetos é intervir para melhorar uma problemática social ou conseguir benefícios educativos, é evidente que o resultado desta intervenção pode ser avaliado. Como nos informa Coutts em relação ao contexto escocês:

(...) como uma grande quantidade de recursos públicos é dedicado à arte pública e comunitária, é razoável perguntar como saber se é eficaz e qual é o benefício? (...) os projetos raramente são documentados e quase nunca avaliados criticamente (COUTTS, 2008:212).

No contexto brasileiro, os projetos desta natureza são raramente avaliados do ponto de vista crítico, como também são negligenciados aspectos que investiguem 0 alcance sociocultural. Pesquisas recentes no campo do ensino de arte no âmbito comunitário tem apontado grande dificuldade na obtenção de dados que permitam uma avaliação processual e dos resultados obtidos, comprometendo a credibilidade de iniciativas 
bem estruturadas, considerando-se que muitas vezes, a arte é implicada em projetos de caráter político, prometendo resultados que seguramente não seriam possiveis de se alcançar.

Aspectos como a característica efêmera de muitas obras, que não deixa uma marca física, ou o abandono por parte da crítica tornam necessário um esforço para estudar, documentar e analisar criticamente a história da arte pública e arte comunitária, assim como melhorar a visibilidade dos projetos atuais. É importante documentar e avaliar os processos, metodologias, percursos e conexões e a repercussão que a palavra colaboração tem, não somente na relação artista-comunidade, mas na de todos os agentes envolvidos.

Somente desta forma seria possivel valorizar a natureza real das práticas colaborativas que, contudo, supõem conflito e diferença, como é próprio da natureza do espaço democrático, mas que normalmente são apresentadas como projetos totalmente consensuados, nos quais não existe nenhuma relação problemática.

A análise da história dos projetos de arte pública em relação à arte comunitária dá uma ideia do caminho trilhado e referências sobre as quais seja possivel construir nosso trabalho, para que, como indica David Harding, os artistas envolvidos atualmente em questões de arte pública, colaborativa e com uma relevância social, com inquietações semelhantes às dos artistas dos anos sessenta e setenta e que dispõem de novas estratégias para o desenvolvimento de práticas mais sofisticadas "não tenham a necessidade de voltar atrás, aos inícios, e reinventar a roda" (HARDING, 2006:137). 
Caplt ul o III

\section{Arte, Experiências e Ter $r$ it Or ios em Processo.}

A experiência no entorno de museus esteve presente desde o início de nossa trajetória profissional, ainda nos anos oitenta, junto ao Departamento de Museus e Arquivos da Secretaria de Estado da Cultura de São Paulo. 0 Museu de Arte Sacra foi o primeiro espaço de pesquisa e ação que veio instigar o desejo de ampliar o debate e a inserção do Museu no campo ampliado da cultura, em especial, das práticas de criação artística e mediação educativo-cultural.

Em 2006 recebemos convite para dirigir o Museu da PUC Campinas e a pesquisa no curso de Pós-Graduação veio colaborar, no contato com experiências voltadas ao contexto da apreciação em museus, para que pudéssemos, frente às inúmeras dificuldades institucionais encontradas e enfrentadas pelo Museu Universitário no contexto da Instituição de Ensino Superior, decidir por uma política de democratização, revitalização, reestruturação do Museu Universitário, pautando a gestão, sobretudo, na socialização do rico acervo de cunho antropológico e etnológico. Saliente-se que 
embora completando 60 anos de existência, 0 Museu Universitário era quase que inteiramente desconhecido pela comunidade acadêmica e cidade de Campinas.

A digitalização do acervo foi o passo inicial, possibilitando a catalogação eletrônica e seu dimensionamento real. A partir deste dispositivo, elaborar estratégias de difusão, ampliação de canais participativos e comunicativos do Museu Universitário estavam entre as preocupações da gestão em curso, em direção a formas de mediação do acervo museológico junto à comunidade. Optou-se, inicialmente, e frente ao desejo de inclusão cultural, pela aproximação com o público especial comumente distanciado das possibilidades de fruição estética em espaços culturais, historicamente atendido pela PUC Campinas.

A diversidade cultural, a alteridade e a interdisciplinaridade foram conteúdos que nortearam o projeto@rte e Inclus@o: Uma Rede de Criação Digital. Tal projeto, fruto da colaboração entre o Museu Universitário e o Centro Interdisciplinar de Atenção ao Deficiente - CIAD se pautou na acessibilidade e inclusão sociocultural de pessoas com necessidades especiais. 0 projeto foi apresentado em Seminário na Pinacoteca do Estado junto aos museus do Estado de São Paulo.

0 DEMA - Departamento de Museus e Arquivos realizava pesquisa sob coordenação da Profa. Dra. Amanda Tojal como parte de sua investigação doutoral acerca da acessibilidade nos museus paulistas. 0 debate gerado entre os profissionais dos museus presentes, subsidiado pelo setor de Educação especial da Pinacoteca reforçou a vocação de Museu Virtual para o Museu Universitário da PUC Campinas, pois tínhamos o entendimento da necessidade de criar formas de interação com públicos diversos, disponibilizando informações e dados sobre o acervo museológico, por meio do desenvolvimento de jogos e materiais participativos que ampliavam e instigavam novas formas de cognição com articulações entre arte, design e tecnologia. 
Os debates ocorridos no início da presente investigação configuraram-se como laboratório e articulações entre o Museu Universitário e as áreas de pesquisa, ensino e extensão da PUC Campinas. Orientaram a implantação de projeto de estágio interdisciplinar junto ao corpo discente, visando a pesquisa acadêmica, a apropriação cultural e a criação coletiva a partir do acervo museológico, conferindo conteúdo ao que viria a ser o Museu Virtual da PUC Campinas.

Os conhecimentos resultantes do cruzamento entre linguagens, áreas acadêmicas e meios técnicos e tecnológicos geraram o primeiro inventário de imagens digitalizadas do Museu Universitário, tendo contado com a contribuição especializada da Profa. Dra. Christina Rizzi, que havia dirigido a divisão de Difusão Cultural e coordenou Projetos de Ação Educativa do Museu de Antropologia e Etnologia da USP1, museu afim ao Museu Universitário da PUC Campinas. A contribuição dos alunos da pós-graduação na condição de escutas atentas operou como campo fecundo de cooperações que contribuiram decisivamente para a escolha do foco da pesquisa de doutorado em torno da ideia do Museu como território aberto a experimentações, processos, colaborações e construção de sentido agenciado colaborativamente. $\mathrm{Na}$ presente investigação são focadas certas matrizes contextuais locais em diálogo com experiências artísticas e interculturais iberoamericanas contemporâneas, confrontando os meios, os contextos e os processos artísticos que estabelecem mediações urbanas.

Partimos do contexto da Arte Contemporânea, da Arte Ambiental e do Museu de Rua - concebido no final dos anos setenta, início dos oitenta, dirigido pelo arquiteto e fotógrafo Julio Abe Wakahara, naquela ocasião, diretor da Divisão de Iconografia e Museus da Secretaria Municipal de Cultura e de dispositivos artísticos inspirados em uma aproximação entre arte-vida proposta por Helio Oiticica, artista brasileiro que funda o conceito "o Museu é Mundo", gerando uma estética relacional participatória, com base em seu Programa Ambiental.
150 mil anos: uma viagem ao passado pré-colonial. Guia temático para professores. Museu de Arqueologia e Etnologia da Universidade de São Paulo 
Investiga-se a ideia de cartografias do afeto: a arte e o cotidiano como formas de compartilhar e desenvolver experiências, processos de apropriação e pertencimento, com o objetivo de incidir na cidade contemporânea como um museu mutante e nômade, aberto a experiências criativas e a processos colaborativos, tendo as micro-histórias locais como componentes de narrativas anônimas e novas cartografias cognitivas, novas paisagens humanas, para configurar visibilidades outras na megacidade. Estabelecem-se diálogos cidadãos e aproximações entre arte contemporânea e a vida cotidiana.

A investigação tem seu ponto de inflexão no marco da realização das Jornadas Abiertas Interculturales: Miradas al Arte Público Contemporáneo. Geografías de la Inclusión y Transformación Social, uma cooperação acadêmica estabelecida entre a Universidade de São Paulo e a Universidade Complutense de Madri, que acolheu as ideias e as propostas desta pesquisadora, desenhadas em torno do projeto processual Museu Aberto, questões que serão tratadas mais detidamente ao longo do presente ensaio.

Nesta medida, a pesquisa se configurou como um caminho duplo de atenção aos comentários, contribuições, depoimentos e ideias sugeridas por eles.

Os fragmentos de cidades que aqui esboçamos são feitos de materialidade e, ao mesmo tempo, de evanescência. Apontam para o futuro, e simultaneamente retomam o passado através de vestígios, sinais. Assim, acreditamos que o que formulamos com este trabalho aproxime-se do ensaio; não pretendemos capturar o terno nem destilá-lo do transitório, mas preferimos, de certa maneira, perenizar o transitório. 


\subsection{MUSEU ABERTO: UM PROJETO EM PROCESSO}

0 projeto Museu Aberto tem origem na experiência desenvolvida na inter-relação entre acervos culturais e o público, na condição de agente formador da cultura urbana, tendo a cidade de São Paulo como lugar, território e matriz de estudo-intervenção privilegiado.

Entende a cidade como campo da experiência estética e ateliê extrapolado para a práxis artística, estabelecendo mediações entre diferentes campos. Neste contexto ampliado, aproxima cidade e museu, estabelecendo procedimentos de investigação e apropriação artística e cultural do espaço urbano, tendo os lugares da cidade como fragmentos de um "acervo" em constante construção e mutação.

Por intermédio do DEMA - Departamento de Museus e Arquivos da Secretaria de Estado da Cultura de São Paulo, onde estagiamos quando da finalização do curso de graduação em artes plásticas na FAAP-SP, na mesma época em que se desenvolviam as experiências no MAC acima mencionadas, tivemos contato com o projeto Museu de Rua, amplamente difundido como prática museal na sua relação com o patrimônio cultural urbano.

Dirigido pelo arquiteto e museólogo Julio Abe Wakahara desde finais da década de setenta, promovia experiências museológicas e estéticas visando um olhar atento para o espaço e patrimônio públicos como política cultural diante do Departamento de Iconografia e Museus da Secretaria Municipal de Cultura de São Paulo. Desenvolveu tecnologia para enfatizar o patrimônio arquitetônico urbano inserindo painéis de fibrocimento que apresentavam reproduções fotográficas relativas ao patrimônio histórico da cidade, em meio ao passeio público, provocando a percepção do passante para as transformações da paisagem urbana no seu cotidiano na metrópole paulistana.

Configurava-se como agente dinamizador de investigações transdisciplinares, por meio de expedições que atravessavam a 


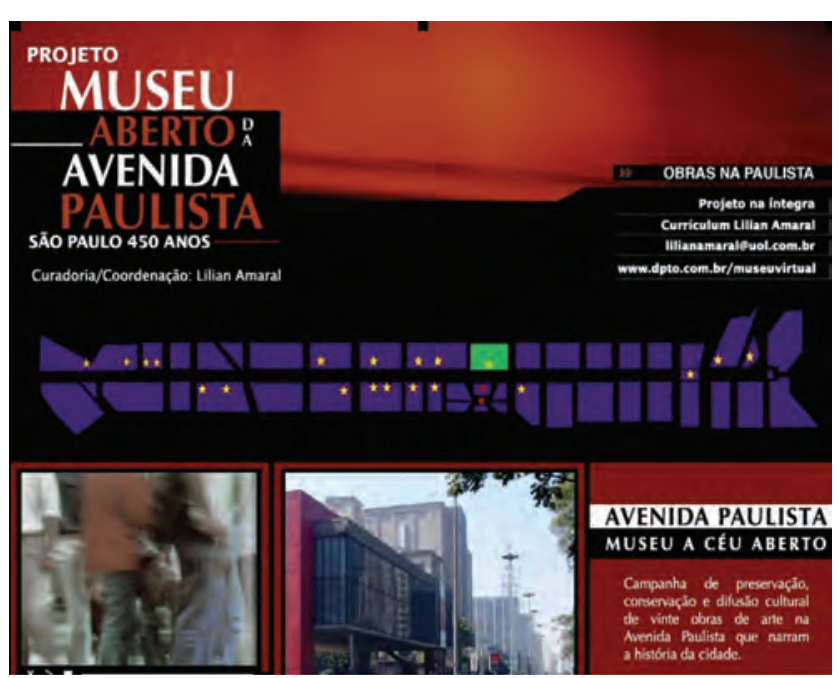

Figura 2 - Tela de abertura do site do Museu Virtual da Avenida Paulista cidade, envolvendo os campos jornalístico, antropológico, histórico, artístico, arqueológico, arquitetônico, ambiental, museológico e educativo. Elaborou publicação processual de extenso material junto à mídia impressa de grande circulação na cidade de São Paulo durante o período de um ano, numa atitude pioneira no campo das colaborações interinstitucionais e interterritoriais tão em pauta na atualidade, como metodologia de pesquisa, ação e difusão da cultura urbana contemporânea.

A primeira imagem de satélite sobre a cidade de São Paulo divulgada na imprensa, alcançando o grande público e apontando outra fisionomia urbana, pela primeira vez, veio a ocorrer por iniciativa das expedições urbanas promovidas pelo Museu de Rua, nas quais se articulavam as áreas acadêmicas, técnicas e artísticas, envolvendo instituições públicas e privadas.

Nesse contexto, o projeto Museu Aberto é concebido como campo de experimentação privilegiado e pesquisa-ação, fundase no conceito ampliado da cidade como Museu, na sua condição antropológica, arquitetônica, urbanística, ecológica e cultural. Provoca reflexões e interferências artísticas no espaço público, desenvolve ações em territórios cuja potência no imaginário social tem forte significação, tais como Avenida Paulista, Heliópolis, Ibirapuera/Vila Mariana, Paranapiacaba.

Entre os dispositivos criados pelo Museu Aberto ao longo de sua trajetória, apontamos o projeto Museu Aberto da Avenida Paulista/Museu Virtual, estudo de campo da investigação desenvolvida no Mestrado na Escola de Comunicações e Artes da USP "Fronteiras do Visível: Arte Pública na Avenida Paulista. Um estudo-intervenção na cidade de São Paulo", 2000, cuja atenção volta-se para a relação das esculturas públicas e o cidadão urbano, promovendo intervenções, apropriações e reflexões sobre a visibilidade da arte pública no contexto da cidade, articulando estratégias que incorporam as mídias e as redes de comunicação urbanas contemporâneas: www.dpto.com.br/museuvirtual. 


\subsubsection{Museu Aberto: Origens e confluências. Diálogos entre Arte e Meio Ambiente}

No marco dos anos oitenta as questões relacionadas ao meio ambiente tomaram corpo e forma política configurando um panorama de articulações em torno de práticas críticas que passam a utilizar os recursos midiáticos para instaurar um amplo debate público. A incorporação dos discursos ambientalistas como plataforma discursiva e de ativismo político mobilizaram o engajamento de novas práticas artísticas no campo da cultura, como as desenvolvidas pela SOS Mata Atlântica, Pró-Jureia no Brasil e o $W W F^{2}$, entre outras organizações não governamentais locais e mundiais.

O Museu de Arte Contemporânea da Universidade de São Paulo - MAC, situado no Parque do Ibirapuera, zona sudeste de São Paulo, o qual divide com a Fundação Bienal até os dias atuais a edificação do pavilhão Ciccilo Matarazzo³ , ocupou papel protagonista na ampliação do debate acerca da arte pública, sua interface com a cidade e o meio ambiente natural e construido. Esta autora situava-se entre os artistas que naquele contexto, tomaram o museu como lugar, espaço e campo de atuação/ espaço de encontro, criação, educação, difusão cultural e ambiental com extroversão na cidade de São Paulo, em meio à vida urbana cotidiana. 0 MAC e suas implicações com os públicos e a cidade converteram-se em campo para o trabalho de arte contemporânea. Frequentávamos intensamente aquela instituição que, particularmente, representou um espaço de experimentações interdisciplinares e interculturais no campo do ensino e das práticas artísticas e curatoriais, de investigação da estética da recepção e das mediações socioculturais, especialmente entre os anos de 1987 e 1993.

Desfrutar e compartilhar experiências inaugurais que alargaram os caminhos e lugares da arte/educação no Brasil em contato direto
2 WWF - World Wildlife Fund. Fundado em 11 de setembro de 1961 em Morges, Suissa. Em 1986 altera a nomenclatura da entidade para World Wild Fund for Nature. Maior rede independente de conservação da natureza com atuação em mais de cem países e o apoio de cerca de cinco milhões de pessoas, incluindo associados e voluntários. Atua no Brasil desde 1971 e tem sido fundamental na recuperação de espécies em vias de extinção como o Mico Leão Dourado e as Tartarugas Marinhas.

3 Obra arquitetônica de autoria dos arquitetos Lúcio Costa e Oscar Niemayer, integrante do conjunto modernista elaborado por ocasião das comemorações do IV Centenário da Cidade de São Paulo, em 1954. 
com experiências internacionais discutidas sistematicamente durante aquele periodo no MAC, conviver com profissionais que pautaram suas trajetórias pela pesquisa no campo da mediação educativo-cultural, da arte/educação em museus e nos espaços públicos urbanos, este foi o contexto comum que permitiu um amplo campo de trocas acadêmicas, artísticas, educativas e colaborativas que tem inspirado agenciamentos contemporâneos para as práticas relacionais e contextuais em debate.

O MAC estabeleceu entre suas linhas de pesquisa a questão e os diálogos entre Arte e Meio Ambiente como plataforma de atuação e de política cultural. Entre os arte educadores e artistas internacionais visitantes do MAC, cujas contribuições apresentaram desdobramentos e ressonâncias locais, apontamos a participação de Eileen Adams, arte educadora britânica, autora de Art and built environment, livro especialmente relevante para nossas práticas artísticas e pedagógicas, e Avtarjeet Danjal, artista indiano que organizou uma imensa instalação artística em torno do lago do Ibirapuera na qual centenas de velas iluminaram uma plataforma flutuante construida para congregar e celebrar a união poética e a consciência coletiva acerca da relação entre homem e meio ambiente.

Ron Neperud em seu livro Contexto, conteúdo y comunidad, classifica o projeto de Arte e Meio Ambiente conduzido por Ana Mae Barbosa na direção do MAC como abordagem multidisciplinar da Ecologia e destaca que "os esforços educacionais de Barbosa combinaram bem sucedidamente arte e ecologia na preservação da natureza e humanos na natureza" (NEPERUD, 1996).

Eileen desenvolveu métodos de apreciação ambiental que inter-relacionavam a percepção estética acerca do ambiente por meio da percepção e observação ativa (desenho), descrição (texto), análise crítica (valoração/julgamento) e sugestão de possibilidades de transformação (criação de imagens e textos que poderiam se converter em projetos concretos). Estes dispositivos apreciativos, sintéticos e comparativos foram 
amplamente utilizados em nossas investigações e práticas no campo da arte pública junto a professores e artistas ao longo dos anos noventa, configurando uma abordagem contemporânea que encorajava formas de participação e pertencimento em relação aos espaços públicos, especialmente no âmbito das escolas estaduais paulistas, quando atuávamos na Diretoria de Projetos Especiais na FDE - Fundação para o Desenvolvimento da Educação, entre os anos de 1991 e 1994. Estimulava-se a comunidade escolar no sentido de elaborar respostas sensiveis ao local, envolvendo-a em processos contínuos de avaliação crítica e criativa, resultando em atitudes propositivas em relação a transformações e mudanças coletivas.

As proposições apontavam para a importância do patrimônio ambiental e cultural na formação identitária, sendo adotada como prática pública preventiva na gestão do patrimônio pela FDE, pois comprometia diretamente o corpo docente e usuários na conservação e preservação criativa do patrimônio público escolar, ampliando sua percepção e articulação com o contexto alargado da cidade. Operava a partir da paisagem urbana cotidiana, destacando a arquitetura e o meio ambiente natural, a publicidade, formas de comunicação urbana e as obras de arte públicas como elementos da gramática visual para ativar a percepção e a imaginação individual e coletiva.

Ampliando as conexões entre Arte Pública e meio ambiente, seguindo essa linha de argumentação, Barbosa nos informa o seguinte:

(...) é interessante perceber que da mesma maneira que outros arte educadores envolvidos com a luta ecológica, ela (Eileen Adams) agora inclui a arte pública em suas reflexões acerca do meio ambiente. Ron Neperud, Don Krug nos Estados Unidos e Lilian Amaral no Brasil seguiram este caminho. (...) A Arte Pública é resistência e/ou diálogo com o público mais amplo 
que aquele que frequenta museus, ou uma comunidade com

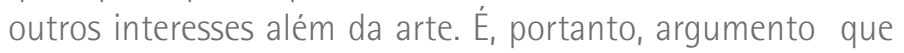
faz parte do vocabulário cultural daqueles que se interessam pelas relações da arte com o meio ambiente (BARBOSA, 1998:124-125).

Ao lado dos artistas apontados por Barbosa, os quais operavam a partir de práticas colaborativas e processuais, com implicações no tecido social pelo viés do meio ambiente e ecologia, destacamos a obra de Frans Krajcberg, artista polonês nascido na década de vinte, radicado no Brasil, tendo tomado a questão da preservação ambiental e a denúncia frente à irreversivel devastação florestal que incidia (e ainda incide de forma alarmante) no território nacional, como prática crítica e foco de resistência cultural. Sua obra foi debatida no interior do Seminário Arte, Educação e Meio Ambiente, ocorrido em setembro de 1991, proposto por esta pesquisadora, acolhido e promovido pelo MAC e Universidade de São Paulo. Contou com a participação de pesquisadores e equipe de arte educadores do museu, artistas, instituições públicas e privadas no campo da educação, meio ambiente, cultura e comunicação.

Composto por um amplo e diversificado campo de interrelações técnico-científico-culturais, o Seminário abordou temas que apontam para a emergência e a atualidade do debate proposto há quase duas décadas em torno da arte, educação, cultura e meio ambiente, os quais se inscrevem na linha de frente da agenda configurada pela geopolítica global contemporânea: Política Cultural para o Ambiente, Arte e Ambiente: homenagem à Frans Krajcberg, Educação Ambiental e Recursos Artísticos, Ação Cultural e Educação Ambiental, GEA: Planeta Terra (Sessão no Planetário situado no Parque do Ibirapuera), Urbanização e Meio Ambiente Construido, Projetos de Integração Arte-Meio Ambiente, XXI Bienal Internacional de São Paulo e as obras de Siron Franco, Alex Flemming e Denise Milan pautadas no comentário crítico acerca 
das relações entre arte e meio ambiente, Estratégias de Ação das Iniciativas Pública e Privada, Comunidades Vegetais, Atividades de Visitas Monitoradas por Biólogos junto aos viveiros e espaços de interesse ambiental do Ibirapuera, Expedição Leitura Cultural e Ambiental do Parque do Ibirapuera, integrando, ainda, atividades de palestra, demonstração e fabricação de papel artesanal com colagem de elementos naturais no ateliê do MAC, voltadas para o público de crianças e jovens, complementadas com apresentação de vídeos e debates voltados para educadores e artistas.

Reproduzimos a apresentação do programa elaborado pela historiadora de arte e arte educadora brasileira Ana Mae Barbosa, então diretora do MAC, apontando a contribuição e emergência do debate realizado naquela instituição:

Os problemas do meio ambiente só podem ser resolvidos através de análises e decisões multidisciplinares. Artistas, professores de arte - assim como arquitetos, urbanistas, comunicadores - tanto quanto geógrafos e ecologistas, têm uma contribuição importante na busca de soluções para potencialização da boa qualidade do meio ambiente. É precisamente no equilibrio não agressivo entre meio ambiente natural e meio ambiente construído que repousam as condições de boa qualidade de vida e as chances da própria sobrevivência. O MAC vem trabalhando desde 1989 em pesquisas e projetos educacionais e artísticos que investigam as possibilidades de desenvolvimento, ao mesmo tempo, da capacidade de construção estética e da capacidade de percepção do meio ambiente. Vários cursos foram realizados, inclusive com professores visitantes estrangeiros; o resultado de uma de nossas pesquisas, com crianças e pré-adolescentes foi, este ano, apresentado no Congresso da National Art Education Association, Atlanta, nos Estados Unidos. Espero que este Encontro, organizado pelo MAC, com a participação da artista plástica e educadora Lilian Amaral - assim como 
4 Texto de apresentação do programa do Encontro ARTE, EDUCAÇÃO E MEIO AMBIENTE, realizado no MAC Ibirapuera, de 25 a 27 de setembro de 1991, com o apoio e participação da Secretaria de Estado da Educação, Fundação para o Desenvolvimento da Educação - FDE, Secretaria do Meio Ambiente, Coordenadoria de Educação Ambiental e Governo do Estado de São Paulo. a exposição "A Mata" que o contextualiza - venha suscitar novas ideias e ajude a implementar inovadores procedimentos, articulando os artistas, educadores, ambientalistas e administradores públicos e privados. ${ }^{4}$

0 panorama apresentado, debatido e apropriado pelos pesquisadores e público participante ao longo de três dias, envolveu a participação de diversas escolas e programas da Universidade de São Paulo, das Secretarias de Educação, Cultura, Transportes, Habitação, Meio Ambiente e Comunicação. Conectou uma ampla agenda interinstitucional que buscava uma atuação articulada para a conscientização e a mobilização social, numa época em que ainda não dispúnhamos de ferramentas de Informação, difusão e mobilização, como o uso de dispositivos que a sociedade do conhecimento e da Informação faz da internet, configurando redes, lembrando que os debates sobre o presente e futuro do planeta estavam, naquele contexto no Brasil, apenas iniciando.

Necessário assinalar a contribuição do MAC na elaboração de propostas de abordagem interdisciplinares baseadas na arte e meio ambiente com propósitos educacionais, tendo influenciado as políticas públicas no âmbito da Educação e da Cultura no Estado de São Paulo, destacava-se no panorama cultural da cidade como locus de convergência para o pensamento transdisciplinar e a prática artístico-crítica.

Os atuais problemas ambientais, tais como o aumento da temperatura planetária, a poluição desmedida, os tsunamis, os "apagões" decorrentes do negligenciamento da gestão energética que têm afetado inúmeras regiões brasileiras ocorridos recorrentemente, as queimadas e o desmatamento contínuo na Amazônia, entre outras emergências locais, regionais e mundiais confirmam a atualidade e urgência da discussão proposta.

Insistimos na importância do debate crítico e propositivo que 
envolve a relação entre arte e meio ambiente e evocamos as advertências e palavras conscientizadoras de Barbosa:

A diversidade, conforme apontou İtalo Calvino, será um dos sete objetos de atenção especial no próximo milênio. A diversidade cultural e a biodiversidade são os mais importantes aspectos dessa valoração da diversidade como principio ético que presidirá as preocupações, as pesquisas e os padrões de vida da próxima geração (BARBOSA, 998:115) 5 .

Imersos naquele contexto, desenvolvemos vasta série de projetos criados com o intuito de estabelecer estratégias e ações a partir do diálogo crítico com os museus e instituições locais, como o MAC, MAM - Museu de Arte Moderna, Fundação Bienal de São Paulo em colaboração com o Centro de Educação Ambiental - criado nos anos oitenta no contexto do debate mundial em torno das problemáticas ambientalistas - o Centro de Convivência e Cooperativa do Departamento de Parques e Áreas Verdes da Prefeitura Municipal de São Paulo, instituições localizadas no Parque do Ibirapuera, que apontavam a pertinência do debate, da formação continuada e suas inserções no campo expandido da cultura urbana, tendo configurado as bases conceituais do projeto processual e colaborativo que veio a ser nomeado, desde então, como Museu Aberto.

0 texto que segue trata da apresentação das bases conceituais e metodológicas do Museu Aberto como prática artística e cultural e contextualiza, a partir de uma mirada crítica e reflexiva decorrente de dez anos de atuação processual, sua inserção como elemento formador da cultura urbana na cidade de São Paulo. Os demais textos aqui transcritos trazem a contribuição de curadores, críticos e a fala dos artistas como produtores de um pensamento e prática crítica acerca da experiência na Urbes.
5 Aponta-se que este texto foi publicado em 1998 no livro Tópicos Utópicos, de Ana Mae Barbosa, Ed. C/Arte, Belo Horizonte, sendo, inicialmente elaborado para uma conferência e apresentado no Congresso da National Art Education Association, Phoenix, Arizona, 1992, há quase 20 anos, portanto. 
6 Texto elaborado pela autora no contexto da XXIII Bienal Internacional de São Paulo, quando esteve à frente da Coordenação da Ação Educativo-Cultural em 1996, tendo sido parcialmente publicado nos anais da ANPAP, 1997, p. 192-194.
Museu Aberto: Arte Contemporânea, a

cidade e o público. A cidade como museu ${ }^{6}$

Nascido da experiência artística e museológica, Museu Aberto surge na contramão ao conceito tradicional de museu. Primeiramente porque não é patrimonialista e tampouco limita-se aos contornos de um edifício. Seu público é o público urbano em meio ao cotidiano e a cidade, o lugar.

Conceitualmente Museu Aberto - projeto de ação artísticocultural e intervenção urbana - configura-se a partir de experiências ocorridas no contato com museus da cidade de São Paulo nos anos oitenta e do decorrente sentimento de isolamento, abandono, distanciamento entre museu $e$ audiência. Objetivando criar alternativas de extroversão para a ação artística e museal no campo ampliado da cultura, constitui-se como espaço de pesquisa-intervenção,

onde a cidade é o lugar, conteúdo e continente, inventando formas de apreciação emancipadora. Museu Aberto articulase a partir de três princípios de ação: Expedições Urbanas - Núcleo de Arte/Educação Ambiental Urbana, Intervenções Artísticas no Espaço Público e Estudos Transdisciplinares, os quais têm a arte contemporânea e a cidade como foco de reflexão. Desde 1986, Museu Aberto vem problematizando a presença da arte no meio urbano provocando a intervenção, participação, apropriação do acervo artístico-cultural da cidade pelo público, colocando em questão as formas de produção e circulação da arte nas sociedades pós-industriais e seu significado no imaginário urbano contemporâneo. Tendo formação interdisciplinar - arte, educação e museologia como artista multimídia desenvolvo uma poética centrada na Produção de esculturas públicas e instalações ambientais de caráter efêmero ou permanente, outdoors que visam a provocação da percepção, da memória e do imaginário urbano. Esculturas em áreas públicas, "artdoors", intervenções na paisagem que operam o limite entre arte e meios de comunicação de massa, instalações temporárias que 
"explodem" as fronteiras entre museu e audiência, imagens produzidas artisticamente para serem manipuladas e fruidas pelo público anônimo das cidades, vêm ocupando espaços físicos e conceituais inusitados, procurando romper com a anestesia e a amnésia a que o individuo, encapsulado, é submetido cotidianamente.

Procurando ativar o campo perceptivo e o imaginário individual e coletivo, a participação-intervenção do vedor-ator é estimulada através da apreciação estética associada à prática artística, visando a estimulação de um olhar crítico, urbanístico e antropológico. Transdisciplinarmente, conteúdos são articulados na revitalização e reinvenção do patrimônio artístico-cultural urbano, patrimônio público, ao qual somos, especialmente os brasileiros, indiferentes. Por intermédio da apropriação criativa, arte-cidade-público operam novas formas de fruição e comunicação urbana, confrontando abordagens, audiências, realidades, lugares e percepções.

Desde 1987 vimos produzindo e atuando com arte pública e a partir de 1995 intensificamos o trânsito e o questionamento entre arte e meios de comunicação de massa, criando e participando de projetos de intervenção artística no espaço público. Outdoors, banners, painéis artísticos operam com mensagens visuais

sintéticas, poéticas e críticas, interferindo, transformando a experiência estética urbana.

0 olhar cotidiano, fragmentado, superficial, descontínuo, lacunar, característico da contemporaneidade, prioriza a velocidade, a mobilidade, é seletivo mas não reflexivo. A experiência artística provoca a percepção, a ver em profundidade, estimula o olhar cuidadoso, apreciativo, crítico e criador?

Nas cidades contemporâneas, conforme comenta Freire ${ }^{8}$, a crescente necessidade de lazer e a restrição acentuada de locais
7 RIZZI, MC; OLIVEIRA, C. OIho Vivo. Material educativo elaborado no contexto da mostra organizada por Glaucia Amaral sobre o Ballet do IV Centenário de São Paulo, SESC Pompéia, 1998.

8 Ver Freire MCM. Além dos Mapas. Tese de doutorado, IPUSP USP, 1995 
para encontros públicos são apenas algumas das razões que possibilitam ao museu um espaço de destaque. Este preserva pouca semelhança com os lugares reservados, no passado, para a fruição artística. Conforme aponta Otilia Arantes $^{9}$, esses novos museus não se distinguiriam de shopping centers. Em relação aos museus e às cidades contemporâneas,

(...) seria descabido suspirar pelo retorno de uma relação hoje inviável com a obra de arte armazenada nos museus, intimamente perdida e inviabilizada numa sociedade de massas; pelo contrário, trata-se de compreender no que deu a expectativa abortada quanto às virtualidades progressistas de uma atenção distraída da arte, como imaginava Walter Benjamin" (ARANTES, 1991, p.3).

Enquanto Arantes observa as discussões recentes concernentes à morte da arte e à sua diluição na vida cotidiana, Christa Burger ${ }^{10}$ aponta para algo mais amplo que se liga à lógica da sociedade capitalista denominada como "Cultura de Museus". A realidade é ofuscada pela ambiguidade da percepção e o museu passa a ser o gerador dessa ambiguidade.

Os Projetos Instalação, integrantes do Panorama da Arte Atual Brasileira do MAM Ibirapuera, 1988/1989 e As Cores do MAC, instalação ambiental e ações artísticas, ambas criadas por esta autora em colaboração com Jorge Bassani em 1989/1990 foram implantados em museus situados no Parque do Ibirapuera e discutiam o estatuto da escultura no campo ampliado, tendo o enfrentamento com o urbano como ponto de embate estético, bem como a ampliação dos canais de extroversão dos museus no espaço urbano, como provocador de questões acerca do patrimônio cultural da cidade. As relações entre Arte e Arquitetura e Arte e Natureza já colocavam em evidência a implicação da cidade no campo da experiência estética e a participação da audiência na

realização da obra.

10 Ver Burger C. The Disappearence of Art: The Postmodernism Debate in The U.S Telos. Summer1986, p. 93. 
No MAM iniciam-se as ações e projetos processuais que, imbricados, passam a caracterizar as práticas do Museu Aberto. No texto de apresentação da obra Instalação, a curadora e historiadora de arte Daniela Bousso problematiza o trânsito entre esferas e campos de prática propostos pelo Museu Aberto, lançando, assim, suas bases conceituais:

Projetado especialmente para esta mostra, o trabalho é uma resposta à situação contemporânea, pois além de questionar a própria cidade e seu imediatismo, nos reporta a questões referentes a museu e meio ambiente. A tensão ótica criada neste trabalho exige um jogo de corpo - por parte do observador que não reforça o ritmo da cidade grande, onde as necessidades operacionais do capital the imprimem uma leitura imediatista. Pelo contrário, a instalação recupera o tempo da contemplação da ambiência urbana através do reforço do próprio ambiente urbano. Questionando o conceito de museu e meio ambiente, a instalação situada na marquise do MAM, Museu de Arte Moderna - do lado externo do espaço museológico, pode ser vista de dentro para fora (através dos vidros do MAM) como de fora para dentro, criando um diálogo entre o museu e o Parque do Ibirapuera, lançando definitivamente o Projeto Museu Aberto, de autoria de Lilian Amaral. (...) 0 encontro entre estes dois artistas reforçou a questão da escala e a discussão ambiental no trabalho de ambos, tendo se dado inicialmente em função da utilização de materiais similares e pelo caráter de interferência que possuem; posteriormente encontraram no Museu Aberto uma estrutura que pode abrigar seus pensamentos, pois para eles as artes, a arte/educação e a arquitetura não são efêmeras, mas devem ser dinâmicas na linha do tempo, acompanhando o desenvolvimento da metrópole e sua trajetória. Criando signos em cima de signos, instaurando a metáfora dentro da metáfora, essa instalação é mais que um simples comentário, pois incorpora o projeto ao lúdico e nos abre, através de seus conceitos, um espaço dialético sem o qual a arte se tornaria um mero exercício formal (BOUSSO, 1988/89). 
Tais ideias apontam e atestam a atualidade e pertinência das práticas críticas agenciadas pelo Museu Aberto desde os anos oitenta, pelo viés da trajetória de um coletivo interdisciplinar poroso a experiências nos campos da pesquisa, criação, produção, formação e difusão da arte contemporânea. Instauram um debate institucional, ampliando as formas de intervenção social dos museus num momento extremamente significativo de expansão e estruturação do ensino da arte, em especial, na cidade e no Estado de São Paulo.

Frente ao papel articulador e de fomento estabelecido pelo MAC da USP, que naquela ocasião inscrevia um amplo debate acerca da Arte e Meio Ambiente, promove-se a formação de equipes multidisciplinares, cursos, pesquisas, mostras, experimentações, residências, conferências, uma verdadeira mutação no panorama institucional que já vinha fermentando a tão desejada a proximação entre a ação cultural, a arte/educação e prática artística.

As práticas tiveram caráter experimental e aglutinador de campos de conhecimento que o contexto permitiu e demandava. Neste sentido, a direção do MAC teve a função especial de promover e encorajar projetos que tensionavam e atravessavam fronteiras, criando novos espaços dialógicos com as diversas culturas que compõem o tecido e a fisionomia urbana.

0 segundo trabalho colaborativo de uma série de três projetos de arte pública desenvolvidos pela autora e por Jorge Bassani no contexto do Museu Aberto em relação à cidade e museus urbanos, propunha como lugar de questionamento e acontecimento o edificio do MAC no Parque do Ibirapuera. Criou-se uma obraexperiência temporária complexa, que desafiava as características arquitetônicas do edifício modernista de concreto, ferro e vidro, exemplar este, tombado pelo Condephaat, caracterizado pela presença de sequências de lances de rampas, verdadeiros obstáculos que discriminavam o público do parque da possibilidade de acesso físico, de fruição do acervo do MAC e da paisagem natural e 
urbana que se descortinava, desde o interior do espaço expositivo em direção ao espaço exterior, da cidade.

Composta por vinte e cinco módulos cromáticos elaborados em madeira, fixados no interior das rampas que configuravam cem metros de subida, dispostos pelos seus cinco lances em forma de zigue-zague, no interior da instalação ambiental figurava um poema concreto especialmente criado pelo artista visual e poeta Antonio Lizárraga para amplificar os aspectos lúdicos que a obra de arte propunha como subversão de comportamentos mecânicos enraizados nas práticas urbanas, tornando lúdica e prazerosa a subida íngrime que permitia o acesso ao Museu:

\section{UMA SARAIVADA DE PÁSSAROS \\ DEPOSITA ÁRVORES \\ NO MOLEJO DE UM PARQUE ALFABÉTICO}

\section{CERIMÔNIAS ESCOLARES FATIAM O SOL EM PARTES IGUAIS CURIOSO \\ APALPA \\ EXTERIORES SEM PRÉDIOS}

NA RAMPA SOMBRAS DE NEON PISCAM CAMBALHOTAS

(Antonio Lizárraga, 1989)

0 poeta parece ter compreendido de forma precisa a intenção dos artistas e, por meio de um texto refinado e inspirado, aponta para o caráter provocador e crítico, ao mesmo tempo lúdico e prazeroso, proposto pelo jogo da arte contemporânea em diálogo com a arquitetura modernista e com a natureza, instalada temporariamente para fruição do público urbano.

Aberto a infinitas formas de leitura, co-criação e pertencimento por parte dos diversos públicos que frequentam o espaço 
democrático que configura o Parque do Ibirapuera, As Cores do Mac abriu espaços, frestas, caminhos para o público urbano, para crianças, jovens, idosos e funcionários do museu que, segundo seus depoimentos e relatos, passaram a ter prazer em subir aquele que se configurava como um monótono, cinzento e repetitivo espaço de esforço físico, passando a representar um espaço de criação e prazer estético, conforme nos informa a diretora do MAC:

"As Cores do MAC é um projeto de denuncia e sobrevivência. Chama a atenção para o meio ambiente construído deslocado de sua finalidade: uma rampa arquitetonicamente projetada para acesso de serviço de um prédio servindo como único elemento de ligação entre o público e a segunda mais importante coleção de arte da América do Sul. Por outro lado, Lilian Amaral e Jorge Bassani ao vivificá-la tornamna suporte estético transformando-a em meio e objeto da construção plástica. Certamente este projeto reverterá em favor de todos que trabalham no MAC, pois servirá de reforço de nosso ego, bastante espezinhado pelas condições dificeis de trabalho, sendo a rampa a nossa maior penalização, pois frequentemente temos que competir com os despojos das feiras industriais e comerciais que despencam seu lixo através dela. Este projeto só pode ser possível por ocasião da Bienal, pois a utilização do prédio todo para mostrar Arte garante o respeito à construção pictórica que Lilian e Jorge projetaram para o MAC. 0 trabalho dos dois, além da qualidade estética, vai ajudar o MAC na sua luta por se tornar visivel.(..) Agradecemos a Lilian e Jorge o prazer visual com que revestiram a "rampa do suplício" demonstrando o poder de intervenção do artista no meio ambiente ${ }^{11}$.

Lembramos, ainda, que com poesia e cromatismo sofisticado o projeto revestiu o MAC de atualidade e visibilidade, tendo sido apropriado pela coletividade e escolhido como locação para o lançamento de um produto audiovisual inovador na época,

11 BARBOSA, AM. Texto de apresentação da Instalação Ambiental AS CORES DO MAC, elaborado pela diretora do museu. São Paulo: Museu de Arte Contemporânea da USP, 1989/1990. 
dirigido à cultura juvenil urbana frequentadora do parque, cuja marca é o deslocamento pelos espaços urbanos, lançamento este no interior da instalação As Cores do MAC, apontando para a revitalização da imagem do museu na paisagem e sua inserção no imaginário social.

Nas palavras dos artistas propositores, pode-se perceber o lugar de intervenção social e cultural que ocupavam tais práticas críticas e suas reverberações ${ }^{12}$.

\section{"AS CORES DO MAC. ARTE-TEMPORANEIDADE-CIDADE"}

Dentro de uma linha de propostas artísticas que promova 0 diálogo entre a Obra de Arte e o Espaço Urbano, "AS CORES DO MAC" deflagra a contradição entre a operacionalidade da linguagem urbana e a linguagem artística. Neste caso a Obra de Arte participa e interfere nesta mistura de signos gerados e geradores pela URBES. Não estamos preocupados com a permanência e sim com a eficácia da Obra de Arte como um reflexo, um microcosmo da dinâmica das relações reproduzidas cotidianamente na pragmática visual urbana. Complementarmente, estas propostas visam instigar a discussão acerca da preservação do patrimônio cultural recente que integrará a História. A proposta da realização da obra "INSTALAÇÃO" integrante do PANORAMA DA ARTE ATUAL BRASILEIRA - MAM SP 1988 - e "AS CORES DO MAC" INSTALAÇÃO/EVENTOS - MAC USP 1989, considera que o papel do artista seja participar diretamente da discussão e produção da cultura sugerindo formas de extroversão da atuação de equipamentos culturais, especialmente dos Museus ao nível do espaço social (AMARAL; BASSANI,1989).

A inserção de totens que funcionavam como módulos sinalizadores da presença artística expandiu a interação do museu com o parque, anunciando ampla programação de encontros em torno de oficinas de arte e de educação ambiental que inscreveram obras efêmeras coletivas na
12 AS CORES DO MAC. Folder de apresentação da Instalação homônima realizada no MAC- USP no Parque do lbirapuera, entre Outubro de 1989 e Janeiro de 1990. Texto de Lilian Amaral e Jorge Bassani. 
do poder - informação, cultura, centro financeiro, onde se situam as instituições do capital transnacional na cidade de São Paulo.

Tais instituições passaram a investir na Arte Pública como marketing cultural, implantando, a partir do final dos anos setenta, intensificando-se ao longo dos anos oitenta e noventa, uma quantidade considerável de obras de arte pública em suas fachadas, como símbolo que confere poder à imagem institucional. Especialmente mobilizados pela criação das leis de incentivo à cultura, como a Lei Sarney, criada na década de oitenta, tais empresas, além de se beneficiarem com a vinculação da imagem institucional à arte e promoção cultural, passaram a abater do imposto de renda o valor integral ou parcial envolvido na operação financeira relativa ao projeto cultural.

A Avenida Paulista converte-se, então, em um museu a céu aberto, no qual vinte esculturas e monumentos recontam a história da Arte com base na história da cidade. Tornam-se, contudo, com o passar do tempo, parcialmente invisíveis frente à aceleração crescente, à tensão urbana, à acumulação e profusão de estímulos multissensórios, tornando-se opacas, disputando de forma voraz a atenção do passante, um esgrimista visual por excelência ${ }^{13}$.

Caminho, projeto colaborativo, concebido como uma escultura ambiental elaborada por esta pesquisadora e pelo arquiteto e artista visual Jorge Bassani, representa a terceira obra da série de instalações ambientais urbanas realizadas conjuntamente, tendo contado com a participação de uma equipe profissional interdisciplinar formada por especialistas - arquitetos, antropólogos, urbanistas, cientistas sociais, gestores culturais, ambientalistas e não-artistas - comunidade, trabalhadores das esferas públicas municipais e empresas colaboradoras.

Estabeleceu-se uma colaboração contínua e grande envolvimento pelo periodo de dois anos, pois muitos dos participantes passaram a estabelecer uma relação mais próxima com a arte contemporânea, a partir das práticas desenvolvidas

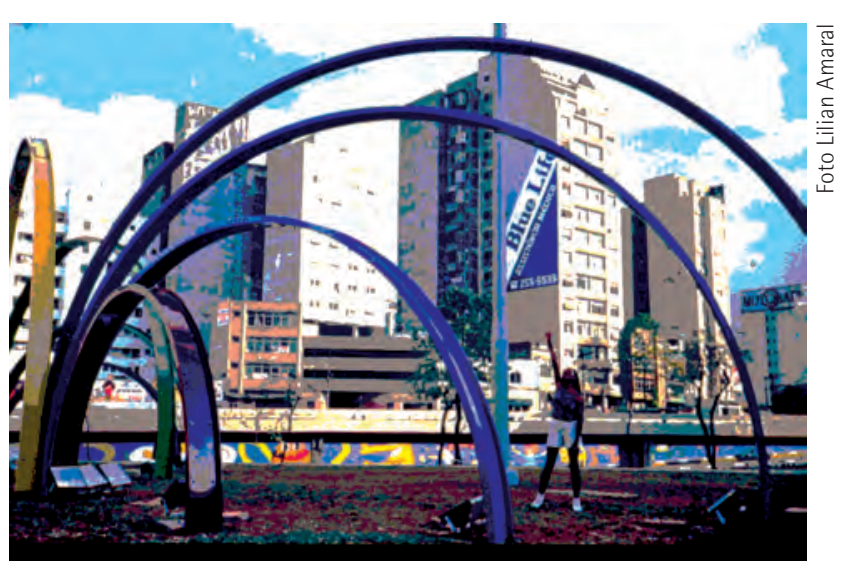

Figura 6 - - Imagem da escultura "Caminho" - Av. Paulista

13 Amaral L. Fronteiras do Visível: Arte Pública na Avenida Paulista. Um estudo-intervenção na cidade de São Paulo. Tese de mestrado defendida na ECA/USP. Linha de Pesquisa em Arte/Educação, 2000. www.dpto.com.br/museuvirtual. 
nos entornos dos projetos realizados em colaboração com os museus, instituições culturais e ambientais situadas no Parque do Ibirapuera, e desde a sua origem, acolheram as iniciativas do Museu Aberto como mediador e campo expandido de práticas dialógicas culturais urbanas. Sem dúvida, essa problemática extrapola os muros dos museus de arte, diz respeito, principalmente, à ampla questão da sensibilidade, da percepção e da memória na cidade contemporânea. Promove-se, dessa maneira, um deslocamento de práticas circunscritas ao Parque do Ibirapuera no diálogo com os museus, para o espaço da cidade, sendo esta, então, entendida e apropriada como um museu aberto.

Neste ponto de nossas reflexões compreendemos que não bastava constatar o tipo de relação estabelecido entre um determinado público e as obras de arte expostas em certos museus e espaços culturais, por exemplo. Era preciso ampliar o debate chegando às suas origens, buscando os lugares indubitavelmente mais amplos e com contornos menos definidos que os objetos estéticos e históricos ocupam no imaginário urbano. Nessa perspectiva, a cidade inteira se transforma num museu e o trânsito entre lugares interiores e exteriores, das construções e das subjetividades, é ponto de partida.

Este breve recorte aponta aspectos do contexto no qual tais práticas colaborativas circunscreveram-se no campo da arte contemporânea na cidade de São Paulo, nos finais dos anos oitenta e inicio dos noventa. Salientamos as iniciativas dialógicas propostas pelo MAC, por meio do projeto "Artista em Residência", possibilitando contato direto entre artista e audiência, expondo não somente o produto, mas o processo de criação e, concomitantemente, o projeto "Museu e Público", especialmente responsável, entre outras ações de extroversão museal, pela grande afluência de público, fruto de deslocamentos estabelecidos entre o MAC Ibirapuera, cidade e público urbano em seu cotidiano.

o Curso Intervenção Artística no Espaço Público ministrado nesse 
mesmo período, amplia e consolida as perspectivas dialógicas entre museu, parque, público e cidade, conforme nos informa a curadora Cristina Freire ${ }^{14}$, então responsável pelo setor de cursos do MAC:

0 Curso Intervenção Artística no Espaço Público, a ser ministrado por Lilian Amaral no MAC, aponta para a preocupação contemporânea de refletir sobre a dicotomia, institucionalização entre a percepção cotidiana da paisagem e a percepção estética circunscrita aos Museus. Neste sentido, a busca do estético no cotidiano implica invariavelmente uma proposta ética que envolve o estímulo de comportamentos preservacionistas, tão em pauta atualmente (FREIRE, 1991).

A ideia de delinearmos um panorama sobre o qual se circunscrevem e configuraram-se as práticas artísticas que deram origem às experiências desenvolvidas em torno do projeto processual Museu Aberto tem por finalidade evidenciar o contexto de complexidade e de relevantes mutações engendradas no campo da arte contemporânea nos anos oitenta e noventa em sua inter-relação com o espaço e percepção urbanas, com a política cultural e esfera pública. Apontam como plataforma proposições interdisciplinares, interculturais e internacionais que se inscreveram diretamente no tecido cultural urbano, proposições com as quais convivemos, nas quais estivemos imersos, tendo influenciado, definido e encorajado as reflexões e práticas críticas atuais acerca do potencial transformador e dialogal da arte pública como experiência compartilhada e da cidade como campo relacional.
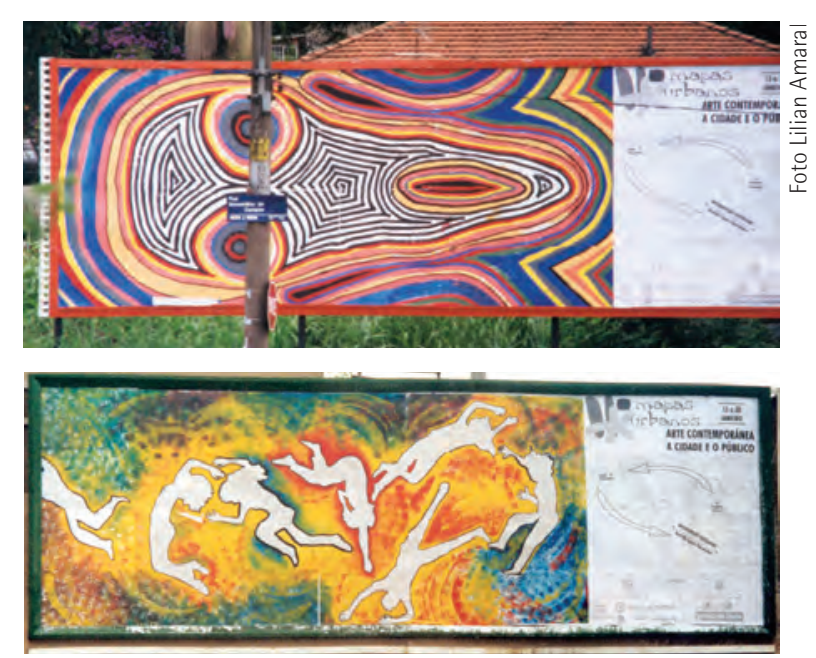

Figura 8 - Imagens Outdoors Mapas Urbanos, Bienal/cidade, São Paulo,1996

14 Freire C. Texto de apresentação do curso Intervenção Artística no Espaço Público, ministrado por Lilian Amaral no MAC, de 8 a 30 de Janeiro de 1991. São Paulo: Secretaria de Negócios Extraordinários/ Assessoria de Meio Ambiente do Gabinete da Prefeitura do Município da Cidade de São Paulo, 1991. 


\subsubsection{MUSEU ABERTO: ARTE CONTEMPORÂNEA, COTIDIANO URBANO E TRANSFORMAÇÃO SOCIAL}

Entendemos a arte como provocadora de encontros e é sobre encontros que constituem novas paisagens humanas que se inicia esta discussão.

Cabe, antes, abordarmoscertasconceituaçõesque têm permeado nossa investigação. Pode a produção artística contemporânea ser tomada como campo potencial para um processo transdisciplinar de conscientização de nossa época? Quais são as perspectivas transdisciplinares de ressignificação dos espaços culturais - os locais tradicionais da arte e os da não-arte, o cotidiano? Como pensar a relação da arte e o público no espaço urbano, uma vez que este espaço, na atualidade, alterou a lógica do monumento, sendo ele próprio o monumento contemporâneo, instaurando cidades-museu, estabelecendo analogias entre cidade e indústria cultural, turismo e entertainment?

Partimos da ideia de que os artistas transfiguram os espaços cotidianos e culturais entre locais de alienação e rituais de conscientização.

Milton Santos, geógrafo brasileiro, comenta que quando o homem se defronta com um espaço que não ajudou a criar, cuja história desconhece, cuja memória lhe é estranha, esse lugar é a sede de uma vigorosa alienação. Mas o homem, um ser dotado de sensibilidade, busca reaprender o que nunca the foi ensinado, e vai pouco a pouco substituindo a sua ignorância do entorno pelo conhecimento, ainda que fragmentário.

0 que está em jogo dentro de uma reflexão sobre papéis e tendências dos locais públicos de circulação da arte e, por conseguinte, cultura e conhecimento, é a preocupação com a geografia de uma sociedade partida na qual tanto artistas quanto não-artistas se encontram.

A interseção entre arte e cultura cotidiana - arte e vida - esteve 
sempre presente na história das manifestações artísticas, porém positivamente como transcendência e imanência, do poético ao sagrado, do decorativo ao ritual. Talvez uma nostalgia de comunhão entre arte e vida sejam reflexos de situações ou estados culturais onde essa categoria, como entendida hoje - Arte, não fosse fragmentada ou mesmo identificada separadamente - tudo era vida/rituais de vida/casamentos/guerras/morte/vida.

Há mais de duzentos anos essa crise de fragmentação é articulada pela cultura hegemônica. Mas, de que crise se está falando? Quando a arte se distancia do cotidiano são inaugurados os templos da arte nos salões e seguidamente, os museus da república, do deslocamento entre mundo da arte (arte erudita) e vida com arte (artes populares, dança, música, teatro de rua etc.). Passaram a ser exatamente mundos paralelos - onde as revoluções artísticas, ou os artistas revolucionários, como Goya, Courbert, entre outros, marcaram a história por cruzarem tais fronteiras.

Da virada do século XX até os dias de hoje, a história das vanguardas reconta justamente esse espírito de insatisfação com o isolamento e a busca de imersão ou "rituais" de confluência entre a Arte e o agora - cotidiano. A produção das vanguardas artísticas modernas e o pós-modernismo recolocam em discussão essa distância entre arte e vida (moldura, pedestal, cubo branco, antimuseu, antiarte). 



\subsubsection{ESTUDO DE CASO: MUSEU ABERTO - A CIDADE COMO MUSEU E O MUSEU COMO PRÁTICA ARTÍSTICA}

\section{Contexto Paranapiacaba}

0 projeto Museu Aberto: a cidade como museu e o museu como prática artística, incorporado como conteúdo e procedimento metodológico da investigação de doutorado "Derivações da Arte Pública Contemporânea", realizada na Escola de Comunicações e Artes da Universidade de São Paulo, desenvolveu-se concomitantemente à investigação em curso na Universidade Complutense de Madri. Tomou como campo de pesquisa e experimentação o processo colaborativo de criação e implantação da Casa da Memória - Núcleo da Memória Audiovisual da Paisagem Humana de Paranapiacaba, espaço integrante do Circuito configurado pelo Museu a Céu Aberto em construção, e referia-se às micronarrativas, às memórias e histórias dos moradores da Vila de Paranapiacaba, que integra o Circuito Museológico "Museu a Céu Aberto", aprovado pelo IPHAN / Ministério da Cultura, 2007 e pela UNESCO, 2008.

Concebido como espaço interdisciplinar para análise das interlocuções e mediações que se dão hoje entre áreas do documentário, seus correlatos e as artes visuais, no primeiro módulo, realizado entre Agosto e Dezembro de 2006, na ECA/ USP, elaborou-se a Videoinstalação MultipliCity - DVD, como estratégia para delinear os contornos do Museu de Experiências Pessoais, um dos territórios para os quais a investigação aponta, utilizando o vídeo como recurso documental de ações artísticas e de construção de narrativas coletivas.

0 segundo módulo do projeto estendeu-se ao longo do ano de 2007, com o desenvolvimento de workshops e pesquisas das quais participam especialistas brasileiros e estrangeiros, no projeto 
Casa da Memória - Núcleo da Memória Audiovisual da Paisagem Humana de Paranapiacaba. Organizou-se, em dezembro daquele ano, em parceria internacional com POCS - coletivo artístico com sede em Barcelona (Espanha), 24h: una linea en la ciudad ${ }^{15}$, projeto realizado desde 2003 que propõe intervenções efêmeras no espaço público, criando uma rede de ações artísticas que ocorrem simultaneamente em cidades europeias e latino-americanas.

0 terceiro módulo configura-se pelo projeto curatorial e museográfico resultante do processo colaborativo de pesquisas e ações artísticas desenvolvidas ao longo de 2007 e 2008 junto ao poder público e à comunidade de moradores de Paranapiacaba. Aborda o imaginário social - moradores e ex-moradores da vila histórica --, aponta aspectos da vida em sua relação direta com o território/contexto, celebrações, conflitos, tensões, negociações, compondo uma polifônica narrativa coletiva.

Ao recebermos o convite para estabelecer uma proposta de curadoria colaborativa visando estruturar o que viria a ser a Casa da Memória, percebemos que somente poderia desenvolver-se um projeto de trabalho colaborativo se este estivesse pautado numa plataforma relacional, ou seja, na condição de um processo que emergiria do convivio com a comunidade local e da partilha de experiências, saberes e campos de prática implicados com o território de relações e espaços afetivos.

0 Documentário MemoryScapes/Paisagens da Memória, 2008, apresentado recentemente no Congresso Sentidos Transibéricos em Beja, Portugal e no Seminário Internacional Acciones Reversibles, ACVIC, Espanha, integra o acervo em processo contínuo de elaboração e pesquisa. Concebido e editado coletivamente, contou com apoio técnico e científico da Universidade Anhembi Morumbi, por intermédio dos Cursos de Cinema e Turismo, tanto para os processos de captação de depoimentos e finalização de imagens como dos estudos relativos ao potencial turístico e circuitos de visitação que passariam a configurar as dinâmicas do Museu a 
Céu Aberto da Vila de Paranapiacaba. Os documentários realizados em 2001 em torno do projeto Cidadeldentidade/HumanScapes, e em 2002, Paranapiacana: um Presente para o Futuro, ambos integrantes da programação do I e II Festivais de Inverno de Paranapiacaba, assim como o vídeo elaborado pelo grupo de Agentes da Memória coordenados pelo cineasta e documentarista André Costa E no meio passa um Trem, 2007, passaram a integrar o acervo de Videodocumentários.

No campo documental, ainda, integram o acervo da Casa da Memória recortes fotográficos resultantes de workshops e da participação dos moradores no projeto 24 horas: uma linha na cidade, propostos pelo artista e fotógrafo Rogério Nagaoka, a partir do projeto Memória Ambulante. Criam palimpsestos compostos por imagens dos habitantes e paisagem local, sobrepostas a depoimentos escritos que comentam a relação dos sujeitos com o território, sua história, seus afetos. Dípticos fotográficos concebidos por artistas - entre os quais Frederico Dalton, artista carioca convidado pela Rede Nacional de Artes Visuais da FUNARTE, da qual a Casa da Memória veio integrar o circuito de cidades participantes - e não artistas, complementam o acervo documental fotográfico concebido por um coletivo temporariamente constituído do qual esta pesquisadora e agentes da memória participaram, circunscritos à Residência Artística.

Na perspectiva de ampliar a interação com o público, um objeto lúdico participativo - Caderno - e uma estação multimídia para criação, pesquisa, edição e fruição de vídeos e documentários, compõem os dispositivos curatoriais que convocam a uma atuação do público a partir das imagens, registros e espaços que constituem o corpus do Núcleo da Memória Audiovisual da Paisagem Humana de Paranapiacaba, uma "casa de memórias coletivas".

Museu Aberto amplia sua inserção em contextos interculturais, notadamente na Espanha, junto à Universidade Complutense de Madri, por meio da organização conjunta do Seminário 
16 Ver Projetos Arte Ação em Campo Aberto, 24 Horas uma linha na cidade, integrante das jornadas Abertas Interculturais, Rio de janeiro - MAC Niterói, Galeria Durex, POCS, Museu Aberto e Coletivo Imaginário Periférico, 2008 e Arte Ação em Campo Aberto, Florianópolis - UDESC/DAV, Museu Aberto, POCS, Corpos Informáticos, Coletivo Rosa dos ventos, 2009.

17 Ver Projeto Porto Alegre: Cidade Criativa, no qual esta pesquisadora foi Curadora Setorial de Artes Visuais, tendo contado com a participação de Ramon Parramon, diretor do projeto Idensitat, no Santander Cultural, Setembro, 2009. Ver também, Arte e Transformação no Território, curadoria desta autora com a participação de Ramon Parramon/IDENSITAT, SESC Santo Amaro, Setembro, 2009 e Mapeamentos Socioculturais: Territórios e Diversidade, São Paulo, SESC Consolação, Instituto Polis e AECID / Centro Cultural de Espanha, Outubro, 2009.
Internacional "Jornadas Abiertas Interculturales: Miradas al Arte Público Contemporâneo. Geografias de la inclusión y transformación social", detalhada mais detidamente no contexto dos debates interculturais ibero-americanos.

Paralelamente, destaca-se a articulação e colaboração continuada com o POCS - Project for Open and Closed Space SculptureAssociation, cujo foco de investigação-ação fundamentase nas relações entre arte e esfera pública contemporânea ${ }^{16}$, assim como com Idensitat, projeto processual no âmbito da Arte Pública Contemporânea, sediado em Barcelona e cuja prática vem desdobrando-se desde 1998, com enfoque nas relações entre criatividade social, ação coletiva e práticas artísticas.

Tais experiências interculturais estão na base da investigação em processo, estando, portanto, permeáveis às contribuições resultantes deste intercâmbio processual que já apresenta desdobramentos em colaborações recentes entre Brasil e Espanha, extrapolando a circunscrição das relações estabelecidas no marco da presente investigação, no contexto internacional e intercultural ibero-americano, tais como publicações, práticas artísticas e investigativas colaborativas, entre outras ações em curso ${ }^{17}$.

\section{Paranapiacaba: um museu a céu aberto}

Paranapiacaba foi a primeira vila ferroviária do Brasil, construída pelos ingleses em meados do século XIX, a partir da qual se desenvolveu a conexão entre o interior e o litoral paulista, estimulando a economia cafeeira, a imigração, notadamente de portugueses e espanhóis e a tecnologia do transporte ferroviário. Constituiu-se como um dos cem sítios de maior relevância mundial de caráter histórico, ambiental e humano, candidatando-se a Patrimônio da Humanidade pela UNESCO em 2008.

A proposta de um Museu a Céu Aberto em Paranapiacaba foi formulada norteando-se pelo projeto de sinalização turística de rua 
do referido sítio histórico, instalado em 2004, a partir de estudos e observações dos principais eixos de circulação, seus cruzamentos e dos principais pontos de interesse histórico. Proposta inovadora de criação de um espaço expositivo e interativo a céu aberto, tendo como plataforma a paisagem cultural da Vila de Paranapiacaba.

Com o intuito de criar espaços integrados à realidade local com intensa interdisciplinaridade e sendo geridos com grande participação social local foi concebida a proposta do museu a céu aberto, incrementando ao museu de rua um circuito composto por cinco equipamentos públicos que abordam temas vinculados ao patrimônio histórico, natural, arquitetônico/urbanístico, sociocultural e humano: Museu Castelo, Centro de Visitantes do Parque, Centro de Referência em Arquitetura e Urbanismo, Clube União Lyra Serrano e, para fechar o circuito, a Casa da Memória.

\section{Paranapiacaba: Caminhos, Trilhas e Percurso Histórico}

"É o alto da serra. Em frente, a alguns decâmetros, abre-se, rasga-se um vão, uma clareira enorme por onde se enxerga um horizonte remotíssimo, um acinzentamento confuso de serras e céu, que assombra, que amesquinha a imaginação. Começam aí os planos inclinados..."

Júlio Ribeiro. A Carne, 1914, p. 80

Paranapiacaba: 'lugar de onde se vê o mar'18, em tupi-guarani. Num dia claro, esta era a visão que tinham os povos indígenas que passavam por ali, depois de subir a Serra do Mar rumo ao planalto. No século XIX, naquele caminho ingreme utilizado pelos índios desde os tempos pré-coloniais, seria construida uma estrada de ferro que mudaria a paisagem do interior paulista e ocasionaria a fundação da vila de Paranapiacaba.

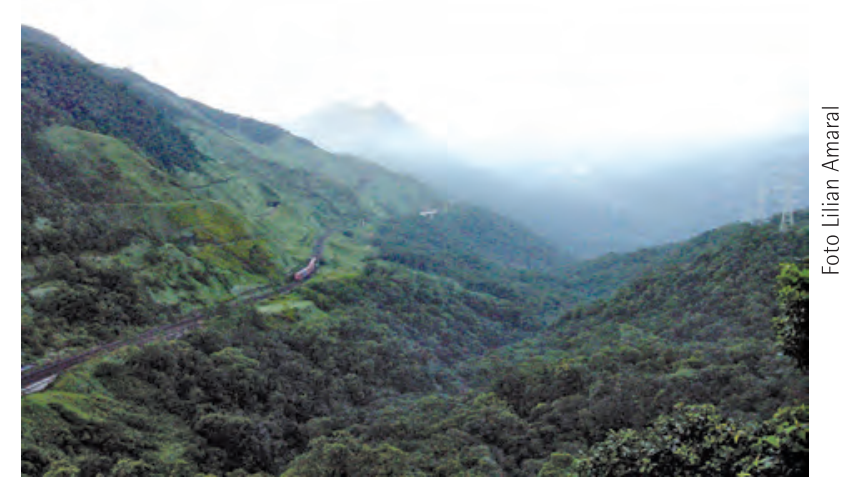

Figura 9 - Serra do Mar

18 Para ampliar a informação acerca de sua origem, o termo Paranapiacaba vem da corruptela de pê-rá-ñái-piâ-quâb-a, que significa "passagem do caminho do porto do mar", de pê (superfície) e rá (encrespada), formando a palavra pê-rá (mar); ñái (porto); piá (caminho); quâb (passar) que com o acréscimo de a (forma no infinitivo a ação do verbo que significa passagem).- segundo o Pe. Luiz Figueira, em sua Arte da Gramática da Língua Portuguesa - de onde mais recentemente foi simplificado para "lugar de onde se vê o mar" ou "miramar", sendo a palavra decomposta nos seguintes vocábulos: parná (mar); apiac (ver); caba (sítio). 
0 fator preponderante para a construção da Ferrovia SantosJundiaí foi a expansão do café, que chegou ao Rio de Janeiro no início do século XIX e logo se espalhou pelo vale do Rio Paraíba. A próxima região ocupada pela cultura cafeeira seria o oeste paulista, já bem no interior do estado. A partir daí, tornou-se urgente encontrar um meio de escoar o café com maior facilidade para o Porto de Santos. 0 mercado no exterior era certo, mas o produto levava dias de viagem em tropas de muares até o litoral.

Os primeiros estudos para a implantação da ferrovia começaram em 1835, mas foi apenas depois de 1850 que a ideia começou a sair do papel, graças ao espírito empreendedor do Barão de Mauá. Ele encontrou nos ingleses os parceiros ideais para executar o projeto. Além de ter interesses em dinamizar o fluxo de exportação e importação brasileiro, a Inglaterra detinha vasta experiência na construção de ferrovias, utilizando a tecnologia da máquina a vapor - algo imprescindivel para vencer as dificuldades técnicas impostas pelo desnível de 796 metros entre o topo da serra e o litoral. Em 26 de abril de 1856, a recém-criada empresa inglesa São Paulo Railway Co. recebia, por um decreto imperial, a concessão para a construção e exploração da ferrovia por 90 anos.

As obras tiveram início em 1860, comandadas pelo engenheiro inglês Daniel M. Fox. Dadas as características extremamente ingremes do trecho da serra, optou-se pela adoção do chamado sistema funicular: o percurso foi dividido em quatro planos inclinados, cada um com uma máquina fixa a vapor que tracionava as composições através de cabos de aço.

A vila de Paranapiacaba era inicialmente apenas um acampamento de operários. Depois da inauguração da ferrovia, em 1867, houve a necessidade de se fixar parte deles no local para cuidar da manutenção do sistema. Assim, construiu-se a Estação Alto da Serra, que também foi o primeiro nome dado ao lugarejo. Por causa da sua localização, último ponto antes da descida da serra, a vila começou a ganhar importância. Também nessa época 
foi fundada, em torno da estação São Bernardo, a futura cidade de Santo André, à qual a vila de Paranapiacaba pertence hoje.

Enquanto isso, a ocupação no interior do estado se consolidava graças à estrada de ferro. 0 comércio e a produção agrícola aumentaram significativamente. Em pouco tempo já era preciso duplicar a ferrovia.

A partir de 1896 começaram as obras. Paralelamente aos trabalhos de duplicação, a vila também sofreria modificações. No alto de uma colina, os ingleses construíram a casa do engenheirochefe, chamada de Castelinho, de onde toda a movimentação no pátio ferroviário poderia ser observada. Na mesma época, foi erguida a Vila Martim Smith, com casas em estilo inglês de madeira e telhados em ardósia para servir de moradia aos funcionários da empresa. Em 1900 o novo sistema de planos inclinados é inaugurado recebendo o nome de Serra Nova.

Do outro lado da estrada de ferro, a Parte Alta de Paranapiacaba, que não pertencia à companhia, seguia padrões arquitetônicos diversos daqueles da vila inglesa. A área começou a ser ocupada por comerciantes para atender aos ferroviários já na década de 1860. Ali também moravam os funcionários aposentados que não poderiam mais usar as casas cedidas pela empresa.

Até meados da década de quarenta, os moradores locais viviam como uma grande família. A vila era bem cuidada, com ruas arborizadas e casas pintadas. 0 clube União Lira Serrano era o centro de uma intensa atividade sociocultural: bailes, jogos de salão, competições esportivas, encenações teatrais, exibições de filmes e concertos da Banda Lira. Outro importante ponto de encontro para fechar um negócio ou conversar sobre política e futebol era a Estação. Nas noites de sábado e domingo, moços e moças bem alinhados, interessados em namorar, caminhavam pelas plataformas largas, como relatam antigos moradores da vila.

Em 1946 termina o período de concessão da São Paulo Railway 
Co. e todo seu patrimônio é incorporado ao da União, passando a ser denominada Estrada de Ferro Santos-Jundiaí.

Em 1957 a Rede Ferroviária Federal, RFFSA, assumiu o controle da malha ferroviária e de seus equipamentos. Nessa época, as rodovias se destacavam como prioridade nacional. Entretanto, gradativamente, o transporte ferroviário começou a perder sua importância no cenário nacional, acarretando um processo de degradação do patrimônio da RFFSA. Na Vila de Paranapiacaba, além do processo de degradação física, consequência da insuficiência da manutenção da estrutura existente, houve também a degradação social, já que a maioria de seus habitantes vivia em função da ferrovia e, com as demissões compulsórias, tiveram que desocupar suas casas. Tais mudanças induziram um novo perfil de moradores, agora não ferroviários.

Este fato é apontado pelos antigos moradores como o início da decadência da vila. Com a desativação parcial do sistema funicular, na década de setenta, mais um golpe: parte dos funcionários é dispensada ou aposentada e outros são contratados para cuidar do novo sistema de transposição da serra - a cremalheira-aderência.

\section{Paranapiacaba: cenário perceptivo, vocação turística. Uma alternativa possível}

Nos anos oitenta, depois de várias denúncias na imprensa sobre a deterioração da vila é criado o Movimento Pró-Paranapiacaba. Em 1986, a Rede Ferroviária entregou restaurados o sistema funicular entre o quarto e o quinto patamares e o Castelinho. As presenças dos patrimônios arquitetônico e cultural de Paranapiacaba, única vila ferroviária em estilo britânico conservada no Brasil, e do patrimônio ambiental, devido aos remanescentes da Mata Atlântica, fizeram com que a Vila e seu entorno fossem tombados 
pelo CONDEPHAAT - Conselho de Defesa do Patrimônio Histórico, Artístico e Turístico do Estado de São Paulo, em 1987.

Nas palavras comprometidas do Professor da FAU-USP, arquiteto Issau Minami, estudioso e defensor do patrimônio cultural que envolve Paranapiacaba em particular ${ }^{19}$, encontramos eco frente à emergência de mobilização em torno da conscientização e desenvolvimento de estratégias de política pública para a vila e região:

"(...) em respeito, pelo menos, ao seu memorável passado, necessita-se com urgência de medidas que impeçam a deterioração de seu espaço. A gravidade da situação exige uma postura da sociedade como um todo, pois tomando a Vila de Paranapiacaba como exemplo, o momento exige seriedade de todos os órgãos que tem o dever de zelar pelas condições de preservação dos nossos bens culturais. Não se pode mais adiar a implementação de propostas de revitalização que levem em conta a destinação social, maximizando o significado do patrimônio cultural: "ferrovia - arquitetura -meio-ambiente" e que abra frente, por exemplo, ao potencial turistico, uma vocação natural da localidade. Com certeza, por trás de cada edificação em pinho-de-riga e de cada plano inclinado da ferrovia batalha-se, incessantemente, pela preservação deste patrimônio e pela liberdade de se criar e discutir conjuntamente os caminhos necessários, razão de ser do próprio homem resgatando seu passado autofágico, buscando seu espaço presente e suas necessidades vitais futuras para o enriquecimento das relações sociais e humanas.

No período entre 1999 e 2000 a Vila de Paranapiacaba foi inscrita na lista dos 100 monumentos mais ameaçados do mundo pelo World Monuments Fund (WMF). Em 2002 a Vila foi tombada pelo CONDEPHAAPASA - Conselho Municipal de defesa do Patrimônio Histórico, Artístico, Arquitetônico-Urbanístico e Paisagístico de Santo André - e pelo IPHAN - Instituto do
19 MINAMI I. Vila Martin Smith, no Alto da Serra em São Paulo, um exemplo típico de "model Company Tonw", Tese de doutorado defendida na FAU-USP, 1994, p.11. 
Patrimônio Histórico e Artístico Nacional -, tornando-se patrimônio municipal e nacional, respectivamente.

A partir de 1999 o municipio de Santo André acentuou sua preocupação com o patrimônio esquecido pelas demais esferas de Governo e resolveu fazer gestões para adquirir parte da Vila de Paranapiacaba em propriedade da RFFSA. Tal negociação resultou em um processo lento que se efetivou em fevereiro de 2002, quando este importante patrimônio passou a ser propriedade dos cidadãos andreenses.

Neste contexto, a administração municipal pautou suas ações em três eixos. 0 primeiro deles foi direcionado à conscientização da população sobre as questões ambientais que incidem no modo de vida em áreas protegidas e desenvolvimento de atividades de convívio com a natureza. 0 segundo eixo buscou a transformação do patrimônio histórico no grande atrativo turístico da região e no terceiro eixo, inscrevem-se as atividades relacionadas ao desenvolvimento econômico e cultural, garantindo, assim, a participação da população junto às decisões da administração municipal e local.

Segundo Eduardo Pin, professor de História e monitor ambiental que mora em Paranapiacaba há aproximadamente 10 anos, a vila está longe do ideal, mas teve um novo rumo. Antigamente, toda a economia era voltada para a ferrovia, que passou por um processo de decadência deixando um rastro de miséria e desemprego, dando atualmente, ao turismo, o papel de transformação deste quadro que parecia irreversível.

Desde então, e com a criação de uma subprefeitura na Vila de Paranapiacaba, inicia-se um processo de forte mobilização comunitária visando estimular novas formas de apropriação local. Objetivava-se a fixação de moradores a partir de atividades econômicas que tornassem a vila auto-sustentável. Inicialmente, no ano de 2000, um plano de desenvolvimento fomenta projetos de cunho artístico-cultural com a criação de Ateliês-Residência 
que buscavam a fixação de moradores com a abertura de espaços de produção artística, artesanal e cultural, possivelmente inspirado na iniciativa de Embú (Embu das Artes, cidade situada a aproximadamente $30 \mathrm{~km}$ de São Paulo, conhecida pela comercialização e produção de artesanato).

Posteriormente, com o projeto de implantação do Parque Nascentes de Paranapiacaba e, considerando-se a importância do patrimônio ambiental composto pelos últimos 5\% de mata Atlântica nacional, passam a ser desenvolvidos projetos de formação dos moradores no âmbito de ações educativas para o meio ambiente, com a criação de associações de monitores ambientais reconhecidos pelo poder público como interlocutores entre a Vila e seus visitantes.

Com a criação do Festival de Inverno de Paranapiacaba em 2000, voltado para fomentar os aspectos de cunho cultural que se inscreviam como marca da atualidade local, foi necessário desenvolver processos de estruturação turística na Vila, ampliando de cultura e ambiental para o campo do empreendedorismo. Com esta iniciativa, chamada de Portas Abertas, pequenas pousadas e restaurantes são instalados nas residências de moradores antigos e novos que se dispuseram a atuar neste setor e, para tanto, participaram de processos de formação. Além das tentativas de preservação dos patrimônios histórico, ambiental e cultural, passa-se a estimular a preservação do patrimônio humano, ampliando condições de moradia, de trabalho, de espaços para oferecer melhores condições de acolhida do público visitante, numa relação de economia criativa com base no turismo sustentável.

Se a vocação histórica de Paranapiacaba tem a marca do passado ferroviário, este se atualiza numa perspectiva pedagógica de caráter turístico-ambiental, configurando-se como um conjunto de extrema relevância patrimonial em contexto nacional e mundial. Após ser reconhecida como um dos mais importantes patrimônios ferroviários no mundo, Paranapiacaba encontra-se atualmente em processo de reconhecimento como Patrimônio da Humanidade pela UNESCO. 


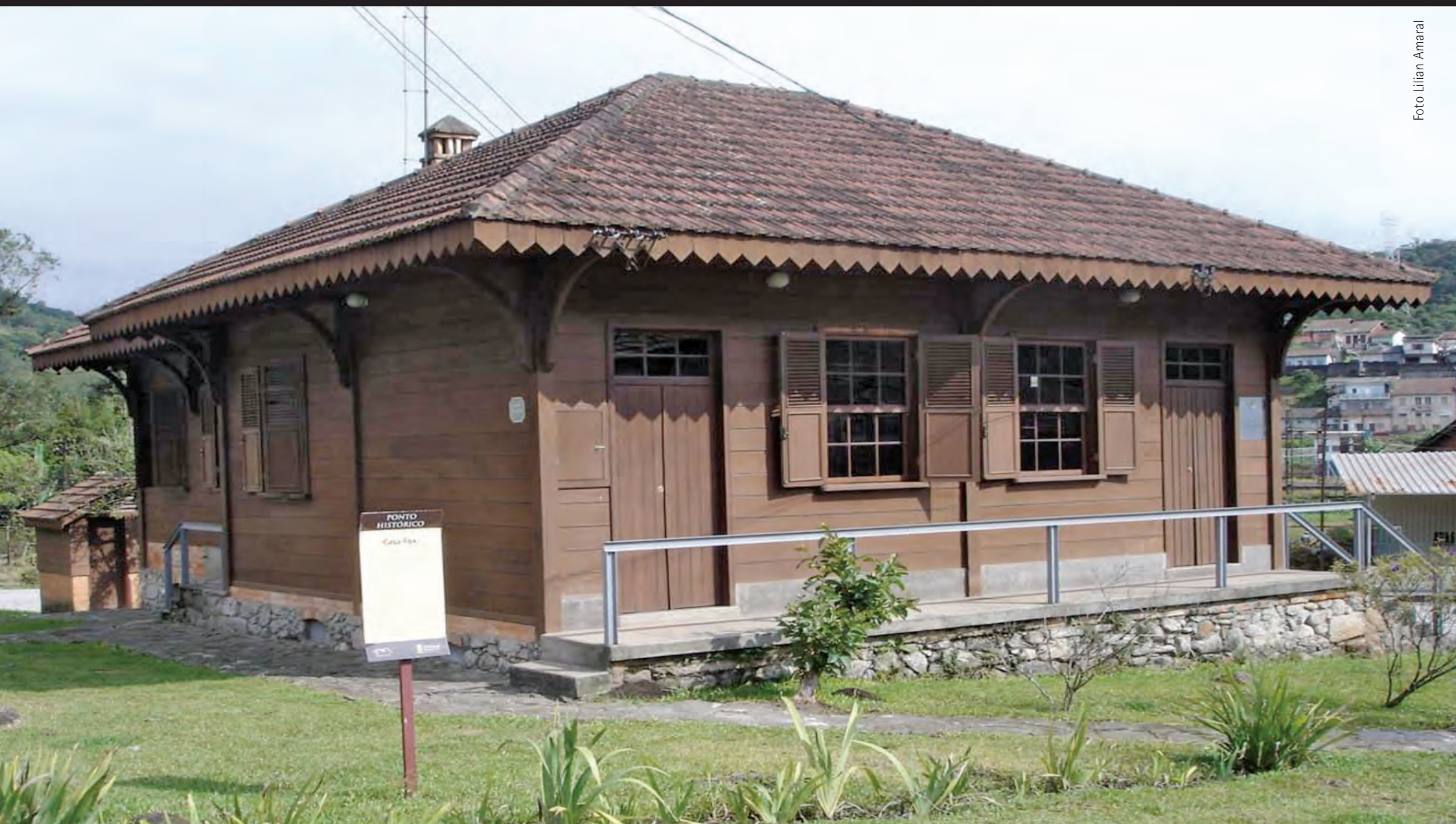

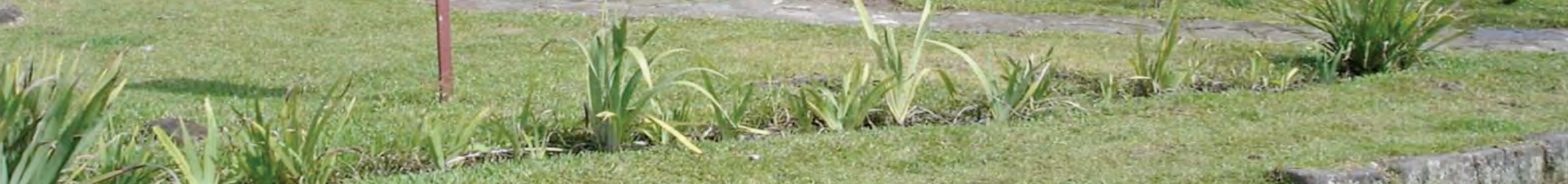

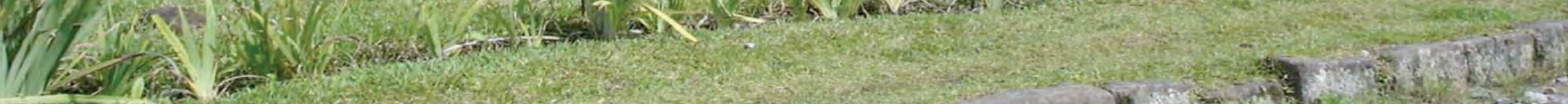

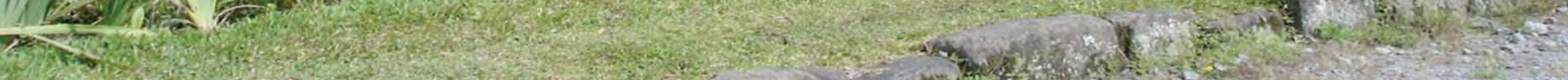

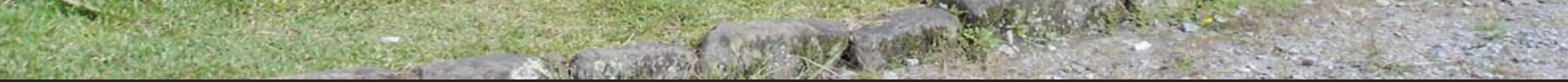




\section{Museu Aberto - Casa da Memória: Núcleo da memória audiovisual da paisagem humana de Paranapiacaba - processo colaborativo, envolvendo artistas e não-artistas}

Proposta de investigar e operar as memórias individuais e coletivas dos moradores da Vila de Paranapiacaba, articulandoas numa perspectiva documental audiovisual sistemática com bases tecnológicas.

A Casa da Memória constitui-se a partir de um Projeto Processual Colaborativo, do qual participam moradores locais juntamente com especialistas brasileiros e estrangeiros em diversas áreas do conhecimento - artes audiovisuais, arquitetura, urbanismo, preservação e reabilitação do patrimônio, história oral, antropologia e arte/educação.

Define-se como Núcleo da Memória Audiovisual da Paisagem Humana em sua interface direta com o território, configurandose como espaço experimental, intermidiático e interdisciplinar contemporâneo, expositivo, educativo e local de encontro para mostras, cursos, palestras, oficinas, apresentações, audições, projeções, assim como um Centro de Documentação e Referência da Paisagem Humana da Vila de Paranapiacaba.

Opera no âmbito da experimentação de práticas artísticas contemporâneas que investigam os imaginários urbanos a partir das fronteiras e potências entre linguagens, meios e contextos, com base em processos colaborativos com perspectivas de apropriação, pertencimento e ressignificação do patrimônio material e imaterial.

Envolve a comunidade de moradores no processo curatorial compartilhado, tem os monitores ambientais e culturais de Paranapiacaba como agentes da memória e mediadores por excelência, estabelecendo, assim, articulações entre arte e vida cultural da comunidade, esfera privada e esfera pública, imaginários urbanos e suas representações, o local e o global. 
0 projeto de criação e pesquisas para a implantação da Casa da Memória estendeu-se ao longo do ano de 2007 e contou com o desenvolvimento de workshops interdisciplinares ministrados colaborativamente por especialistas brasileiros e estrangeiros.

A articulação de lançamento do projeto da Casa da Memória com o projeto 24h: una linea en la ciudad promoveu reflexões e ações acerca dos imaginários urbanos da Vila de Paranapiacaba em diálogo com outros contextos culturais nacionais e internacionais, estimulando produções audiovisuais que foram incorporadas ao acervo em construção da Casa da Memória. Em dezembro do mesmo ano realizou-se o projeto 24h: una linea en la ciudad.

A articulação de lançamento do projeto da Casa da Memória com o projeto 24h: una linea en la ciudad promoveu reflexões e ações acerca dos imaginários urbanos da Vila de Paranapiacaba em diálogo com outros contextos culturais nacionais e internacionais, estimulando produções audiovisuais que foram incorporadas ao acervo em construção da Casa da Memória.

0 foco atual da pesquisa em processo é o estatuto contemporâneo do documentário como lugar para a prática artístico-crítica, tendo nas memórias individuais e coletivas, nos imaginários urbanos e na arte relacional colaborativa sua estrutura e corpo poético.

Num momento em que o fluxo, deslocamento, transitoriedade e velocidade caracterizam a dinâmica de trocas - informações, conhecimento, comunicação contemporânea, e em um contexto em que o Brasil se vê pressionado a repensar sua infraestrutura no âmbito dos transportes, tendo como agravante os recentes desdobramentos resultantes do colapso aéreo especialmente vivido na cidade de São Paulo em Julho de 2007, parece-nos extremamente oportuno colocar em pauta discussões que apontem perspectivas de revitalização do transporte ferroviário que há tanto tempo tem sido relegado à obsolescência e ao esquecimento, apontando possibilidades de de preservação do 
patrimônio material e imaterial, promovendo a mobilização crítica e a transformação social por meio de diálogos mediados pela arte e criatividade.

\section{Casa da Memória - Projeto Colaborativo - Interterritorialidade: uma condição contemporânea ${ }^{1}$}

Operamos com um conceito expandido de Arte com base em ideias concebidas por criadores de imagens, sons, movimentos e textos, confrontadas por críticos, escritores, antropólogos, psicanalistas e educadores, potencializando discussões acerca dos dispositivos de criação, recepção, mediação, ensino e difusão educativo-culturais, aprofundando questões e apresentando experiências cujas origens se dão em outros territórios e contextos e que no contato intercultural poderão iluminar novas práticas e reflexões.

Ao atravessar domínios, eles e elas analisam os mecanismos de produção e apropriação da cultura visual na atualidade, discutindo a interterritorialidade das diversas linguagens: verbal, audiovisual, cênica, assim como as diversas mídias e contextos nos quais operam as multissignificações humanas.

Transitar entre territórios converteu-se em condição humana contemporânea marcada pela transitoriedade, deslocamento, fluxos e aceleração. Territórios entendidos como contextos definem os lugares de existência. Territórios culturais, étnicos, religiosos, parecem definir melhor a noção contemporânea de lugar. Que lugares, num mundo marcado pelo nomadismo, impermanência e simultaneidade as manifestações artísticas podem ocupar?

Hoje debatemos com muita insistência e clarividência o lugar da arte - fora do museu, no cotidiano - e mais ainda, a própria instituição "museu" se vê pressionada a conquistar um lugar no 
20 Referência ao conceito de ARTografia (A/R/Tographer - artist/ researcher/teacher), termo que designa o trânsito e deslocamento da figura do artista, pesquisador, professor por contextos que articulam a participação do outro/comunidade como co-autor do trabalho criativo e investigativo, termo e prática pedagógica desenvolvida pelo Grupo de Pesquisa em Cultura Visual da Universidade British Columbia, no Canadá, desenvolvido por Rita Irwin no artigo A/rl togrfia: uma mesticagem metonimica in Interterritorialidade: mídias, contextos e educação. São Paulo : Editora Senac SP / Edições Sesc, p. 87-104 cotidiano urbano na era do espetáculo, ora confundindo-se, ora competindo com shopping centers. A informação e a comunicação que caracterizam a cidade contemporânea vem se tornando cada vez mais agudamente crítica para transcender a sociedade de consumo. Tudo está para ser visto, consumido, assumido ou descartado.

\section{A Mediação como Experiência, Compartilhamento e Exercício de Alteridade}

Neste panorama complexo a figura do mediador - artista/ professor/pesquisador ${ }^{20}$ - reveste-se de relevo especial como elemento chave nos processos de intercâmbio cultural, compartilhamento de saberes e gerador de experiências, contribuindo para a dinamização das interações e redes sociais por operar na articulação e no agenciamento da criatividade social, ação coletiva e práticas artísticas.

Alargar a reflexão na configuração de campos de conhecimento, partindo das relações entre Arte/Educação, indo além, extrapolando-as, revela um esforço em não tratar a mediação como disciplina do saber associada a um gênero artístico específico, parecendo-nos ser produtivo considerála como não-disciplina, sem lugar discursivo definido, justamente por entender que, enquanto procedimento interativo e flexivel, moldável a inúmeras variáveis e negociações permanentes, posiciona-se e desenvolve-se em zonas intermediárias, intervalares, de traçado difuso entre as coisas, os saberes e as pessoas, e entre estas e os territórios. Talvez esta identidade transitiva seja justamente o seu principal atributo no campo cultural.

Pierre Bourdieu, ao elaborar a Teoria de Campos estabelece que toda organização social está estruturada por uma série de espaços que têm suas regras próprias e leis de funcionamento, onde as 
relações de força se estabelecem entre os diferentes agentes que intervém e a posição que nele ocupam.

Daí que se possa falar de campo educativo, campo cultural, campo político, campo científico...21.

Os campos são constituídos de produtores, consumidores, distribuidores de bens e instâncias legitimadoras e reguladoras, cujas características, regras e conformação variam de acordo com sua história e relação com o campo de poder ${ }^{22}$.

Bourdieu (1993) analisou o campo da produção cultural em sua luta pela autonomia e legitimação, e como esta, é inseparável da luta que se estabelece no setor dominante quando entende a cultura como uma forma simbólica conectada ao poder, domínio e distinção ${ }^{23}$.

Este alargamento em relação à sua afirmação como área do conhecimento, tende a potencializar e ampliar a performance mediadora naquilo que ela tem como proposta de prática crítica para promover relações significativas entre sujeitos e contextos. Não corresponde, assim, a uma suposta anulação de conflitos e insucessos. Opostamente, ao abrir mão de estratégias apriorísticas e apaziguadoras, o mediador assume e cultiva uma atitude investigativa, de escuta, sustentando as incertezas em lugar de recusá-las, extraindo delas e dos conflitos sua potencialidade criativa e sua força de resistência cultural, atribuindo valor às dúvidas, buscando perceber as singularidades dos sujeitos e especificidades do processo em meio ao qual está imerso e onde opera como agenciador.

Atua, assim, em uma plataforma que, por não estar definida de antemão, pode dar-se a partir dos elementos existentes e com as respectivas características e contribuições, com a duração da interação com os sujeitos e os contextos que os sustentam. A plataforma da mediação, ao agregar e dinamizar os interesses
21 Ortega L. De los Puentes para los Campos. Reflexiones en torno a la Divulgación de la Ciencia. Razón y Palabra, Número 32, Abril-mayo 2003 en http://www.razonypalabra.org.mx/anteriores/n32/lortega. html

22 Sánchez Dromundo, RA. La teoría de los campos de Bourdieu, como esquema teórico de análisis del proceso de graduación en posgrado. Revista Electrónica de Investigación Educativa, 9 (1) 2007, en: http:// redie.uabc.mx/vol9no1/contenido/dromundo.html.

23 Bourdieu, P. The Field of Cultural Production. New York: Columbia University Press, 1993 
e vozes polifônicas envolvidas tem o potencial de configurar-se como lugar de encontro, criando arquiteturas de relações.

É neste lugar transitório e consciente de sua posição interterritorialque o mediador busca provocar, estimular e articular os diversos repertórios, códigos e inquietações dos sujeitos em suas relações entre si e com os contextos nos quais se inscrevem.

0 mediador busca, então, trazer para o lugar do encontro os códigos - linguagens, desejos e visões de mundo dos indivíduos, grupos sociais e contextos, criando um campo relacional no qual todos esses componentes configuram-se como plataforma sobre a qual se desenvolve o processo e os dispositivos de mediação. Portanto, os recursos que compõem a referida plataforma poderão, ao longo do processo, produzir novas e flexiveis experiências, espaços de entrecruzamentos, entrechoques, recodificações e negociações.

Quanto aos contextos, os entendemos como "categoria" abrangente, podendo incluir conjuntos de saberes, manifestações culturais, produções artísticas, tradições, fenômenos sociais e naturais, objetos, códigos, repertórios, enfim, tudo aquilo que integra os universos culturais, material e imaterial, histórico e conceitual, passivel de análise, interpretação e rearticulação. 0 mediador transita por estes territórios, experimentando estabelecer recortes e investigações em campos e sobre temas de interesse coletivo, desenvolvendo, a cada plataforma de mediação experienciada, formas de aproximação e provocação do diálogo entre os sujeitos e o mundo.

0 processo de mediação colocará em relevo determinados conteúdos e proposições em detrimento de outros, considerandose a formação e repertório do mediador. 0 que está em jogo é compreender seu papel de forma alargada, não propriamente como um especialista neste ou naquele campo, justamente para 
nunca perder de mira as zonas de fronteira e intersecção entre os saberes, interterritorialização de espaços e tempos. Conforme mencionamos, é exatamente este seu campo de atuação e onde agencia os lugares de encontro, a tal plataforma de operações que se dá entre diversos territórios.

0 mediador é um observador atento das dinâmicas interpessoais que alinhava os modos de perceber dos sujeitos e os objetos com os quais interage, sendo, também, um propositor. Por esta razão, as noções de identidade/alteridade, reciprocidade, negociação, deslocamento, recombinação, flexibilidade, reconhecimento, recodificação e ressignificação Ihe são tão caras, posto que contribuem para o agenciamento de experiências coletivas.

Desta forma, o mediador privilegia a experiência, a interação e o compartilhamento. Permeada por diálogos, negociações, interpretações, acordos e divergências, a experiência de mediação adquire um valor em si, distanciando-se da perspectiva utilitarista e instrumental que tenderia a reduzi-la à mera condição de transmissora de informações e explicações ${ }^{24}$.

Permeada por uma ética do compartilhamento, a mediação busca deflagrar e impulsionar situações nas quais os sujeitos envolvidos participem de maneira efetiva e singular das discussões em processo, expondo e contemplando seus múltiplos pontos de vista, instaurando uma

integração alocêntrica, que foge de um centro predeterminado e se organiza por meio de centros emergentes, e que conta também com a participação do observador (ator) para criação de múltiplos centros organizativos. Parece complicado, mas é esse processo que chamo de interterritorialidade e que vai além da interdisciplinaridade ${ }^{25}$.

Assim, propicia-se uma pluralidade de falas e movimentos de deslocamento que caracterizam a qualidade da dinâmica mediadora, 


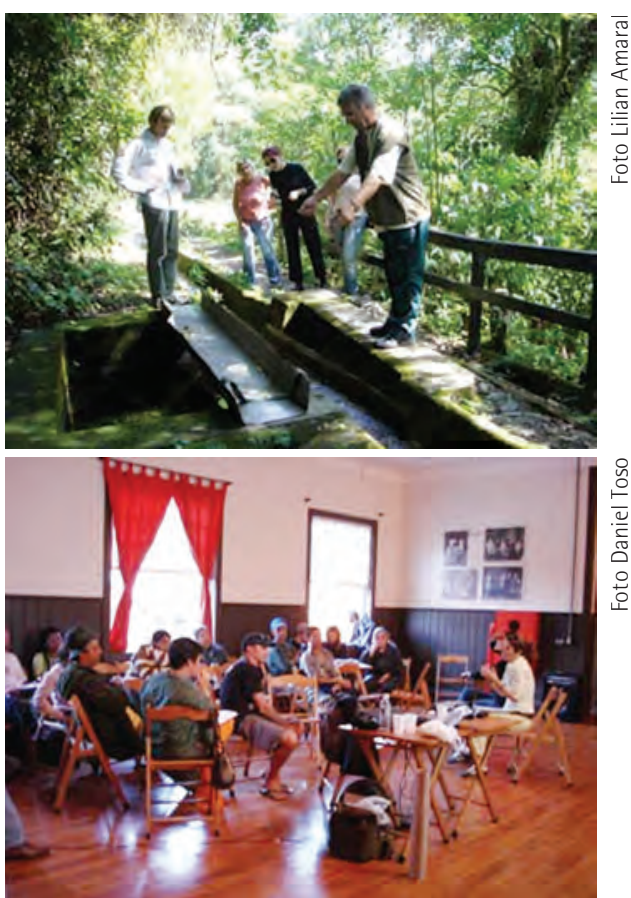

Figuras 11 e 12 - Workshop Da Estetização à Arte Colaborativa proporcionando efetivos espaços de intercâmbio e alternância de hierarquias entre os diversos interlocutores, instigando, assim, à uma escuta atenta e ao exercício de alteridade.

\section{Metodologia - Investigação processual como modalidade de práxis aberta}

Percurso Imersivo: Pesquisa-ação / Estudo-intervenção / Projetoprocesso

0 processo de formação, mediação e construção coletiva do Projeto da Casa da Memória - Núcleo da Memória Audiovisual da Paisagem Humana de Paranapiacaba foi composto por uma série de workshops e experiências compartilhadas com a comunidade de Paranapiacaba nas quais artistas, não-artistas, monitores culturais e ambientais conviveram com especialistas de áreas confluentes no campo da arte e esfera pública, entre as quais artes visuais, arquitetura e urbanismo, fotografia, história oral, cinema e documentário, arte/educação, cultura visual, antropologia, arte tecnológica, turismo, educação patrimonial e meio ambiente.

- Formação de Agentes da Memória

Grupo formado por cerca de 30 participantes ao longo do projeto-processo.

\section{Workshop Internacional}

1. Da Estetização à Arte Colaborativa. Agosto, 2007

Prof. Dr. Daniel Toso

Conteúdos:

Experiência Pessoal

Relato Social

Corpo Percurso Território 
2. Documentário: texto-imagem. Oralidade, memória, fragmentos.

Agosto, 2007

Elizabeth Chanampa - Documentarista, roteirista e diretora de arte para cinema e vídeo.

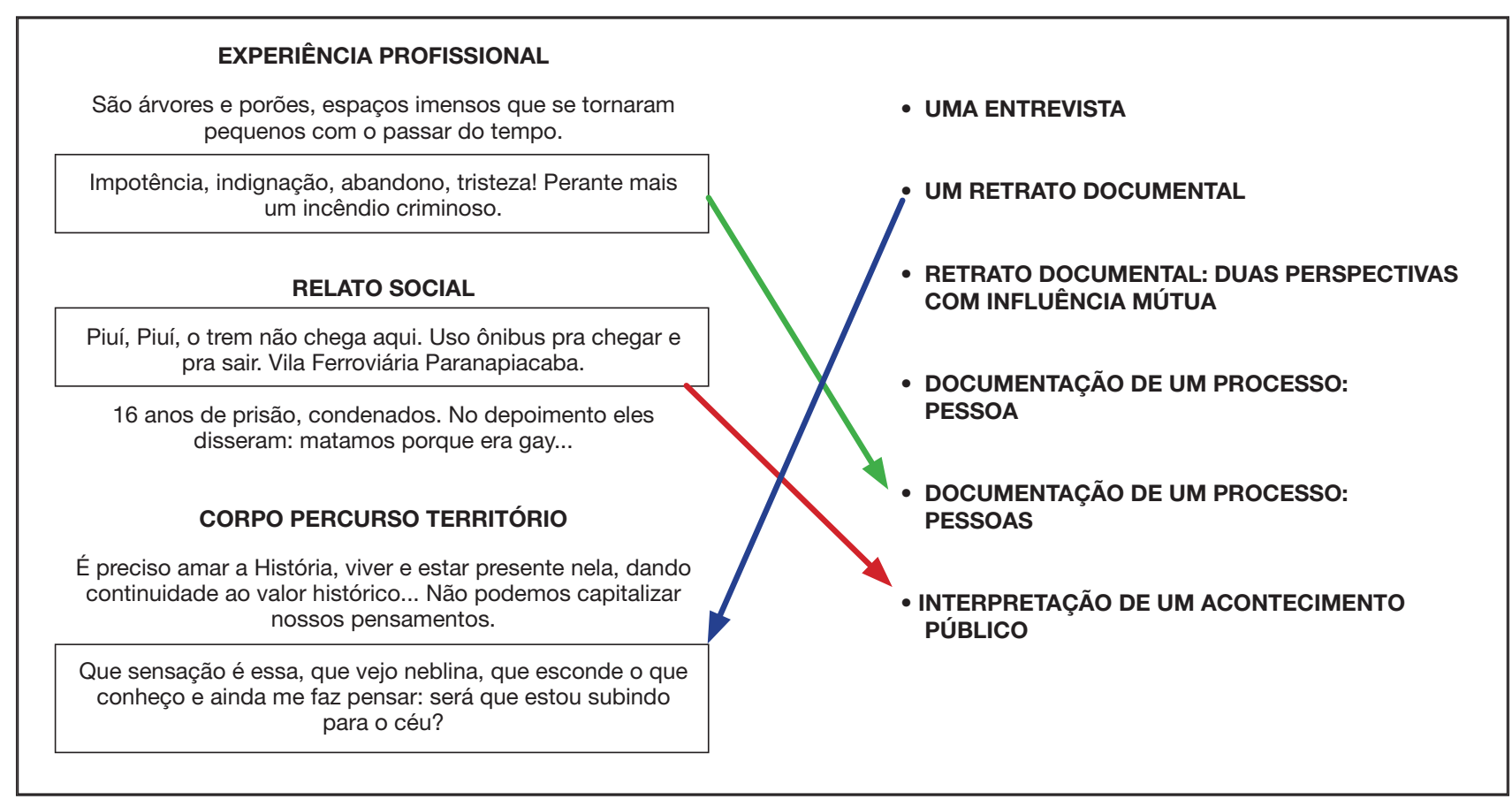

3. Memória Ambulante - Mediações entre Arte

Contemporânea, Espaço Público e Imagem Fotográfica.

Setembro, 2007.

Rogério Nagaoka, fotógrafo.

Proposta de contato com os princípios óticos, que busca aproximar a produção e a reflexão artística ao meio sociocultural, estabelecendo um diálogo entre o trabalho de artistas, um lugar e sua comunidade. 


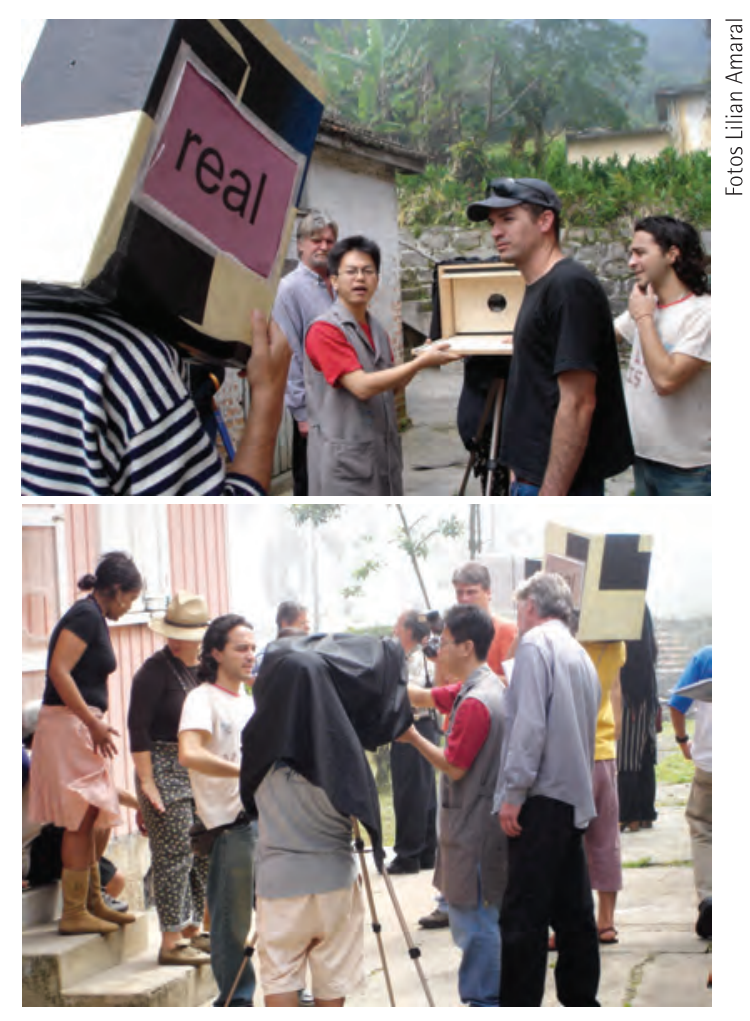

Figuras 13 e 14 - Workshop de processos fotográficos
Parte da proposta é difundir o conhecimento sobre processos fotográficos a partir da percepção visual. Será desenvolvida uma reflexão sobre a cidade e produzidos trabalhos numa ação coletiva, que envolverá as relações dos participantes com o lugar e sua história.

\section{Objetivo}

Gerar um fluxo de relações entre a comunidade e o trabalho artístico.

Propor uma reflexão sobre o espaço, através da arte.

Ambulante é o trabalho de arte pública do Espaço Coringa, que realiza ações em diferentes espaços públicos da vila de Paranapiacaba e convida os transeuntes a se aproximarem do princípio fotográfico - uma câmera escura ambulante adaptada em um carrinho que se desloca, apreende e projeta imagens.

\section{Ação}

Documentação poética para as percepções de um cinema vivo estabelecido entre uma perspectiva artística, a cidade e o olhar de seus habitantes.

Percursos, Territórios. Profa. Ms. Lilian Amaral. Artista Audiovisual, pesquisadora no âmbito da Arte e Esfera Pública, Setembro, 2007.

\section{Arte/Cidade/Percepção/Deslocamento/Espaço} Revelando Limites da Percepção

Soundscape - Tour. Ativar o espaço por meio da exploração multisensorial. Síntese - Percepção ampliada.

\section{Atuação no Espaço, Coleta}

Diferenças entre VER e OLHAR. Escolha de um objeto com forte potencial associativo/memória em relação ao lugar. Escolha de 
um local significativo em Paranapiacaba.

Revisitando e transgredindo os limites da percepção.

\section{Observação Ativa}

Desenvolvimento de métodos de investigação que podem caracterizar-se das seguintes formas: classificatório, documental, performático, construtivo/desconstrutivo, inserção de textos, imagens, sons etc.

\section{PAISAGEM REVELADA: a observação e o caminhar como prática estética}

Na cultura contemporânea, nossos sentidos estão sempre tentando se defender contra a inundação de estímulos e ruídos de toda ordem, tanto visuais e sonoros quanto intelectuais.

0 Workshop "Paisagem Revelada: A Observação e o Caminhar como Prática Estética - Parte I", ministrado por Lilian Amaral, artista visual e curadora da Casa da Memória teve entre seus objetivos estimular a imaginação e a percepção acerca do lugar e do ambiente, levando o participante a fazer observações e conexões entre seu corpo e o espaço ao seu redor. Através das práticas imaginativas sugeridas durante o workshop, pode-se encontrar uma nova possibilidade, esperança, surpresa e também encantamento que inspire, ensine e sugira uma nova maneira de habitar ou experienciar o mundo.

Proposta: Perscrutar as paisagens interiores a partir de estímulos sensoriais que articulam percepção e memória. Estimular a percepção crítica e criativa acerca da paisagem urbana cotidiana para a qual lançamos olhares indiferentes, sem percebermos que é desta ambiência (ou falta de horizontes) que resultam certas características da experiência contemporânea (sentido de isolamento na multidão, perda da subjetividade, transitoriedade e superficialidade).

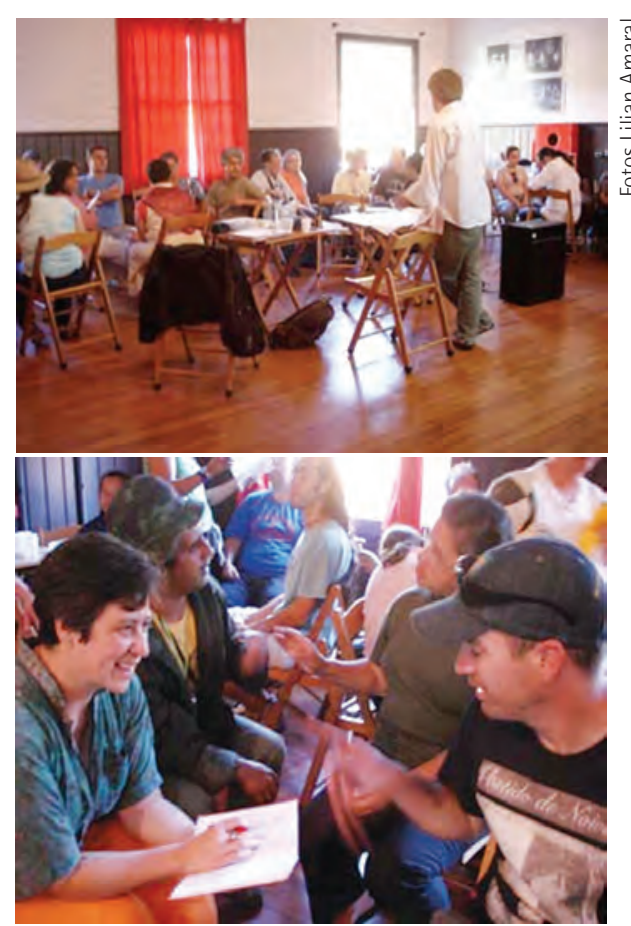

Figuras 15 e 16 - Workshop Da Estetização à Arte Colaborativa 
Considerando que vivemos na era do espetáculo e da superexposição, propõe-se uma ação contrária, uma desaceleração na experiência simples de contemplação da paisagem.

Tendo como pano de fundo a Vila de Paranapiacaba, pretendese que as ações/intervenções realizadas no processo em curso possam revelar também paisagens ocultadas pela aceleração imposta na contemporaneidade e desvelar aspectos da história local ao lado de sua atualidade, trazendo para o plano perceptível as constantes transformações urbanas e seus desdobramentos na vida cotidiana.

\section{Descrição \\ 2. Metodologia}

Atividade desenvolvida

- Soundscape - tour. Coleta/deslocamento individual pelo entorno ao ar livre por 10 minutos, focado na captação de paisagens sonoras. Estímulo à percepção, a estados de atenção, seleção.

- Sintese - Descrição individual das paisagens sonoras, aberta à participação e colaboração do grupo. Identificação das diversas camadas sonoras e sensoriais - objetivas e subjetivas, as associações suscitadas, nomeando a experiência por meio da síntese - verbo - que ative, indique a ação, o posicionamento de cada sujeito participante.

A Percepção e o Caminhar como Prática Estética SOUNSCAPE / TOUR

Circuito ativado - Agentes da Memória

Som ganha importância no lugar, como se a vila fosse um amplificador, o som reverbera.

Pedro:

Silêncio. Passos, sons de moçada conversando na praça, som de pássaros e som de rádio de uma casa, som de pássaros dando referência de sons locais, torneiras abertas, máquinas de lavar, vozes de crianças, rádio, passos de crianças em silêncio, casa com 
rádio baixinho, algumas movimentações de carro que tampa tudo (não conseguiu ouvir o som das árvores).

Verbo: "Conviver".

Gabriel:

Várias camadas; seus próprios passos, vento, cachorro e criança, carro encobrindo, crianças de skate batendo no chão, conversas, gritos, rádio bem alto - música evangélica, silêncio. Houve momentos de silêncio absoluto, entrecortados.

A palavra que sintetiza é "misturado". Verbo: "Misturar".

Wilson:

Silêncio. Pássaros, música, pessoas conversando, galinha, passarinhos. Telefone tocando, crianças, barulho de máquina. "Eu gosto de silêncio e de barulhos de máquinas".

Verbo: "Pensar".

Ameya:

Levantei da cadeira, respirando. Sons de vozes conversando. Sons descendo a escada. Tênis resvalando. Som oco do assoalho na sala de troféu. Cumprimento de outra pessoa. Som de machado. Vibração aguda de som de máquina. Grupo de alunos, som Dexter. Sons coreanos - conversa. Estalar da própria mandibula.

Verbo: "Viver"| "Vivendo".

Doel:

Desliguei o cérebro. Hinos evangélicos. Ouvi um sabiá. Passos da cachorrinha seguindo-o. Crianças discutindo. Latidos de outros cães. Escutando o vento e a neblina. Alarme do castelo. Ouvi uma locomotiva diesel na estrada. Mas, antes, desligar dos outros sons.

Verbo: "Desligar".

Cida:

Som de rádio. Em volta do clube, pássaros cantando. 0 vento forte balançando as árvores. Silêncio, em casa. Barulho da máquina passando na ferrovia. Trabalhadores arrumando a cerca do fundo. Crianças brincando no parquinho. E barulho da turma chegando. 
Verbo: "Experimentar".

Rosana

Ouvi pessoas andando. Vozes de um grupo de pessoas. Ferramenta do jardineiro. Cantar dos pássaros, antes mesmo de sair, lá fora, mais evidente. Barulho do vento nas árvores. Rádio. Latir dos cachorros, ouvindo os próprios passos e o respirar. Quando houve conversa, quebrou o ambiente - barulho humano, no retorno ao salão.

Verbo: "Andar".

Ever:

Passos na escada de madeira. Pássaros. Rodas de skate no cimento. Serra elétrica cortando madeira.

Verbo: "Escutar".

Renata:

Barulho de pássaros, do vento. Pessoas conversando, dando risada. Rádio. Latidos de cachorros.

Verbo: "Unir" (diversidades).

Lisa:

Ouvi os passos, na escada. Salão do Lira: acústica. Ao passar na janela, som de pássaro e vento, interferindo na percepção. Enxadinha do trabalhador. Fundo: crianças, cachorro. Intervenção de carro.

Som de frente: pássaro. Fundo, sempre, o tempo todo.

Verbo: "Captar".

Felipe:

Começou lá fora, escutando passos no paralelepípedo. Passos na terra. Pássaros, o tempo inteiro. Perto do núcleo de cerâmica, barulho das máquinas. Ao lado da casa de máquinas abandonada, o som do silêncio que havia lá dentro - espaço desabitado. Barulho de água (nascente ou esgoto). Barulho do vento nas árvores, que se moviam. Voz da Lisa.

Verbo: "Caminhar". 


\title{
SINNTESE
}

As análises das coletas sonoras individuais discutidas coletivamente acessaram outras camadas.

AO FINAL DAS DISCUSSÕES AS PERCEPÇÕES AMPLIARAM PARA: Misturar (espaços e tempos) = Observação da mistura passageira Conviver (com as diferenças) $=$ Conflitar

Pensar (mais atentamente, seletivamente) $=$ Analisar

Viver (experiência / buscar plenitude) = Vivenciar

Desligar (do que não interessa) = Editar

Experimentar (novas sensações / liberdade) = Libertar(-se)

Andar (atento) $=$ Observar

Escutar (consciente)

Unir diversidades

Captar (espacialmente) = Captar organizadamente / "Capturar"

Caminhar (escolhendo $/$ atento) $=$ Selecionar $/$ Editar

0 resultado foi surpreendente, rompeu com alguns estereótipos relacionados às paisagens da memória, revelando singularidades, numa arqueologia das memórias soterradas.

\section{A Percepção e o Caminhar como Prática Estética}

\author{
5. História Oral - Documentação e Coleta de \\ Depoimentos \\ Constituição de Acervo para a Casa da Memória. Outubro, \\ novembro, 2007.
}

Profa. Dra. Sonia Maria Freitas. Doutora em História Social/USP, especialista em História Oral pela Universidade de Essex, GrãBretanha. Ex-pesquisadora e curadora do Memorial do Imigrante. 


\section{Objetivos}

Abordar a potencialidade e as diferentes possibilidades da história oral em seus aspectos teóricos, metodológicos e práticos.

Incentivar o desenvolvimento de projetos de história oral pelos habitantes de Paranapiacaba buscando a reconstrução da memória do lugar e a constituição de acervo em processo para a Casa da Memória, tendo como meios os recursos audiovisuais.

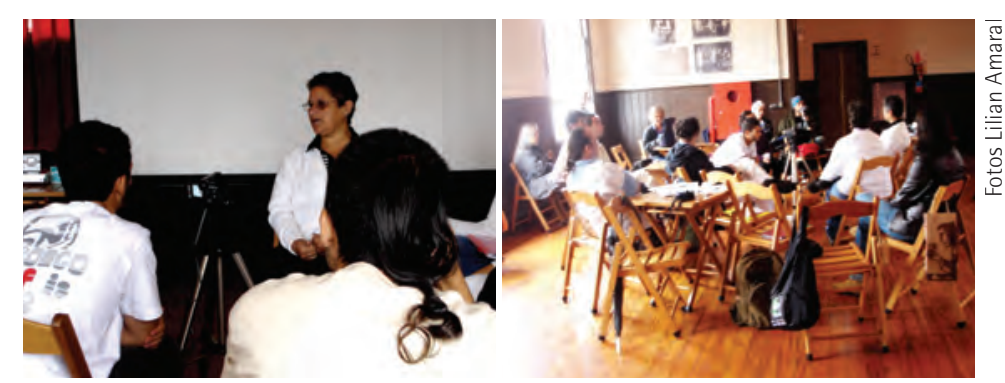

Figuras 17 e 17 - Videodepoimento 1 - Maria da Silva Barros (Cida)

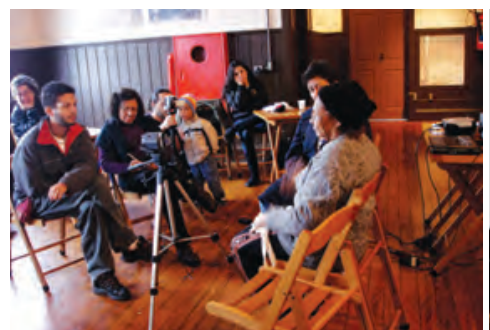

Figuras 19 e 20 - Videodepoimento 2 - Anésia Maria de Jesus

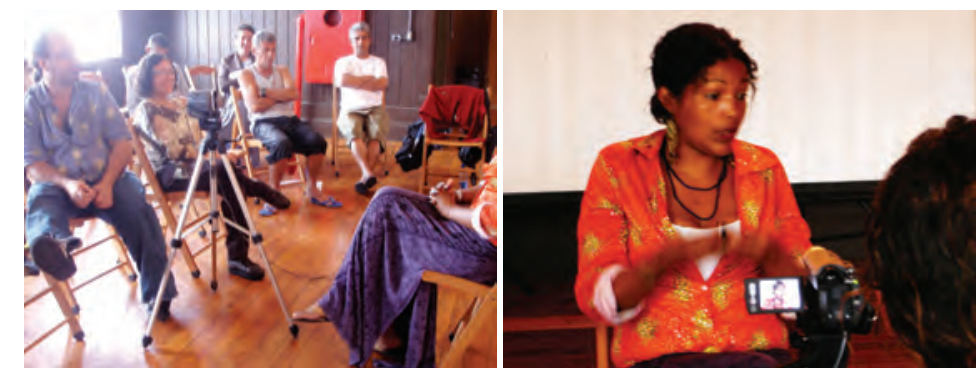

Figuras 21 e 22 - Videodepoimento 3 - Elisângela Caboclo da Silva
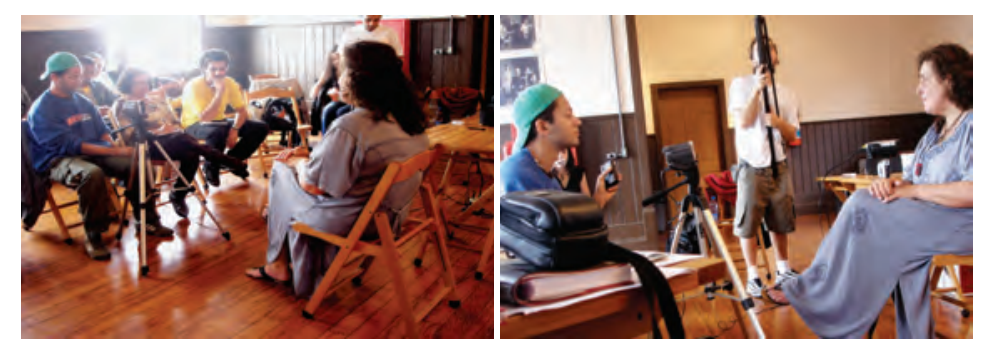

Figuras 23 e 24 - Videodepoimento 4 - Regina Azevedo Miguel 
6. Documentário - Imaginários Urbanos: Mediações Entre Imagens Privadas e História Pública. Prof. André Costa. Documentarista, Professor da FAAP e diretor do Olhar Periférico. Novembro, 2007.

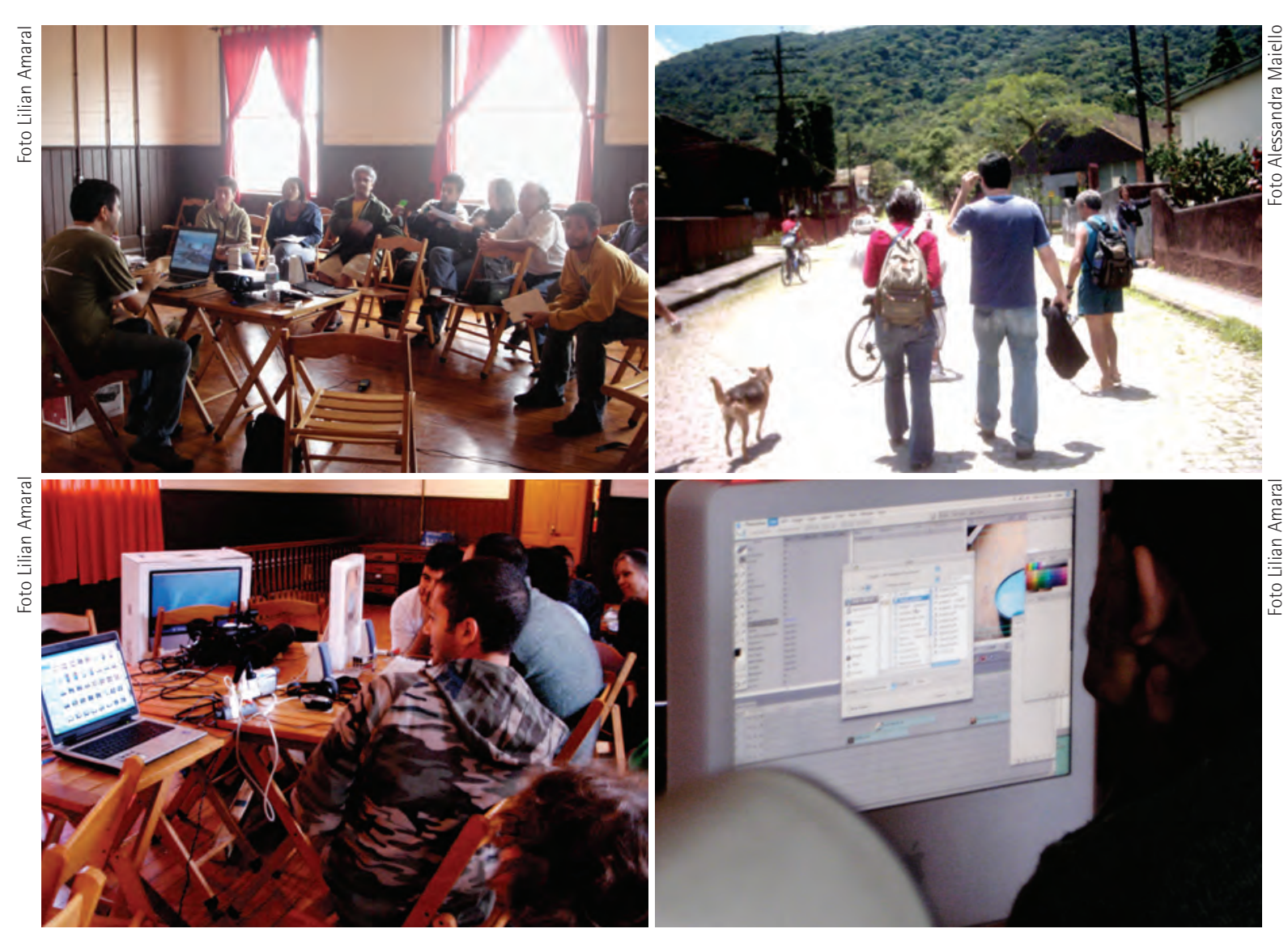

Figuras 25, 26, 27 e 28 - Atividades de investigação da paisagem audiovisual Registro, edição e finalização de Documentário "E no meio passa um trem", projeto coletivo realizado pelos moradores participantes do projeto de formação de agentes da memória. 


\section{Proposta de Dispositivo}

0 Documentário seria uma maneira, um instrumento para se tornar conhecido um determinado conteúdo. Todo documentário tem o aspecto do real, mas que real é esse? Todos temos a possibilidade de recompor, de remontar "o tempo".

Som: justaposição. Proposta de criação e edição de um Documentário transitando entre o privado e o público. Dípticos de imagens justapostas e uma pista sonora colocada no Time Line. Criação de contextos de produção de sentido.

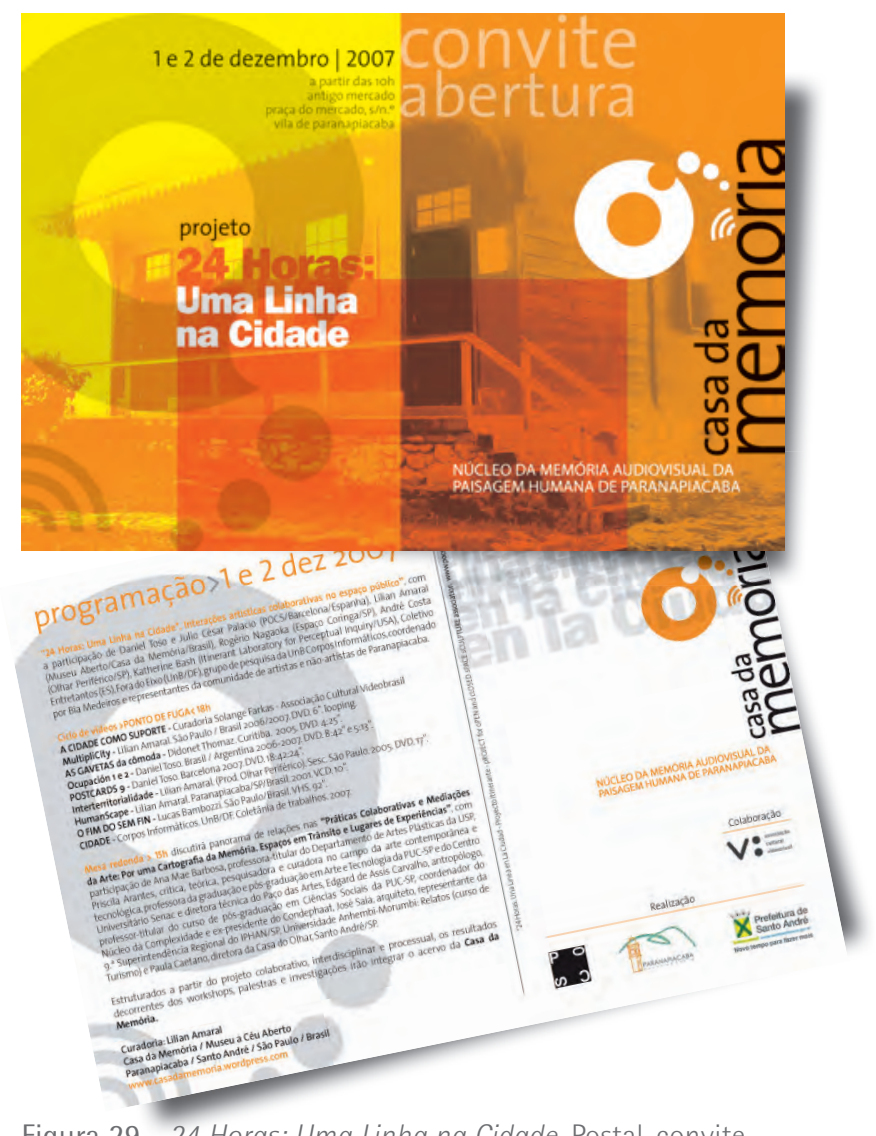

7. Casa da Memória - 24 Horas: Uma Linha na Cidade. Lugares da Memória, Memórias do Lugar. Interações Artísticas e Não-Artísticas no Espaço Público

Dezembro - "24 Horas: Uma Linha na Cidade. Lugares da Memória, Memórias do Lugar. Interações artísticas e nãoartísticas no espaço público"

Realização de reflexão pública e discussão aberta do processo colaborativo de elaboração da Casa da Memória, integrante do circuito temático Museu a Céu Aberto, aprovado pelo IPHAN. Mesas redondas, residências artísticas e ações artísticas no espaço público da Vila de Paranapiacaba e na web, com a participação de Daniel Toso e Julio Palácio (POCS - Project for Open and Closed Space Sculpture Association-Barcelona); Lílian Amaral; Rogério Nagaoka; André Costa; Katherine Bash (EUA); do coletivo Entretantos; Fora do Eixo; do grupo de Pesquisa da UnB Corpos Informáticos; coordenado por Bia Medeiros; Luis Felipe Volpe e Dado Mota e representantes da comunidade de artistas e nãoartistas de Paranapiacaba. 

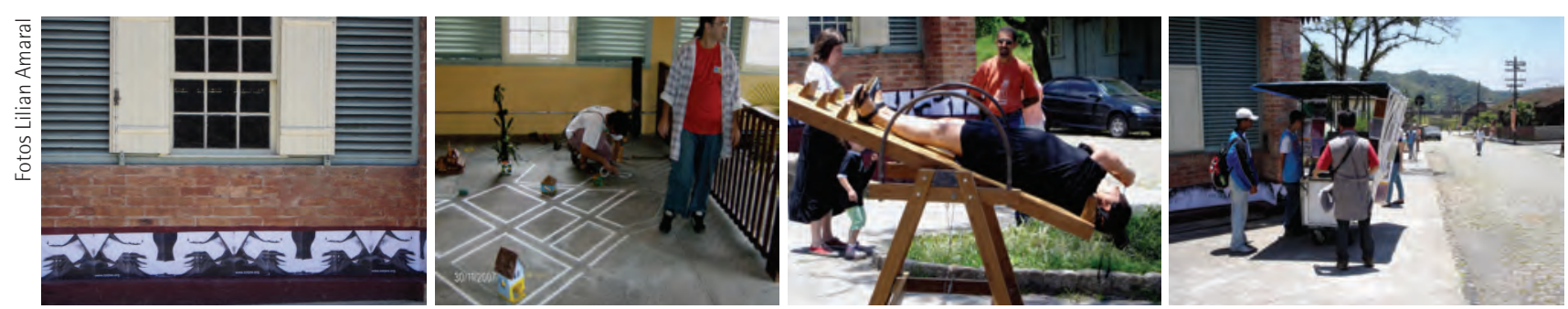

Figura 30 - "24 Horas: Uma Linha na Cidade. Atividades
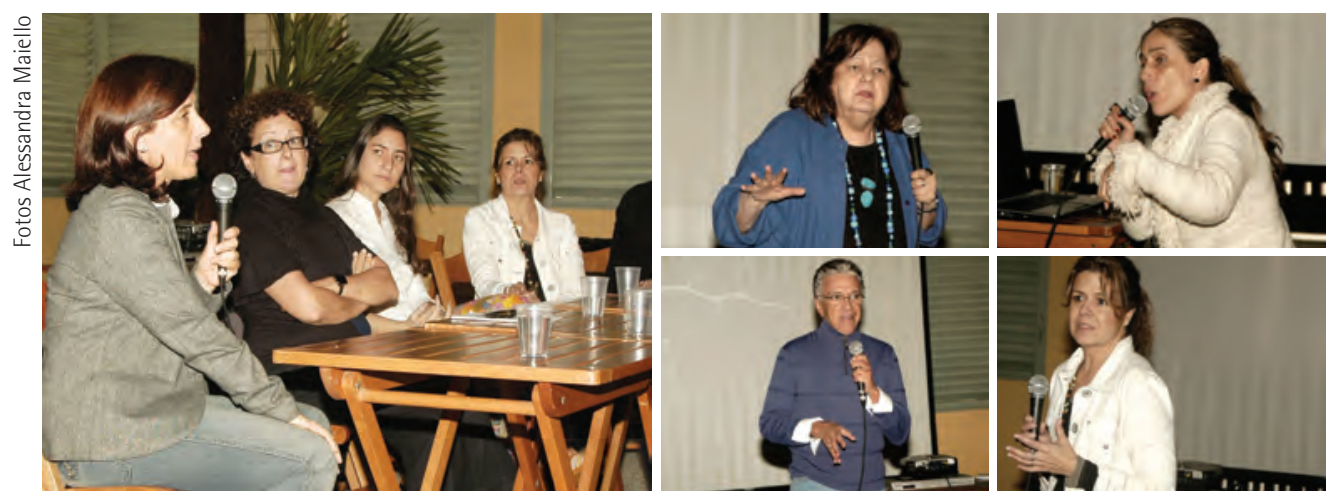

Figura 31 - Mesa redonda "Práticas Colaborativas e Mediações da Arte: Por uma Cartografia da Memória. Espaços em Trânsito e Lugares de Experiência"

Mesa redonda "Práticas Colaborativas e Mediações da Arte: Por uma Cartografia da Memória. Espaços em Trânsito e Lugares de Experiências"

Participação de Ana Mae Barbosa, professora livre-docente da ECA/USP; Priscila Arantes, crítica, teórica, pesquisadora e curadora no campo da arte contemporânea e tecnológica, professora da Graduação e Pós-Graduação em Arte e Tecnologia da PUC-SP e do Centro Universitário SENAC e diretora técnica do Paço das Artes; Edgard de Assis Carvalho, antropólogo, professor livredocente do curso de Pós-Graduação em Ciências Sociais da PUCSP, coordenador do Núcleo da Complexidade e ex-presidente do Condephaat; Paula Caetano, diretora da Casa do Olhar, Santo André/SP. 
Ponto de FUGA - Ciclo de vídeos - abordará relações entre Arte, Memória, Cidade e Identidade, uma parceria com curadoria de Solange Farkas, da Associação Videobrasil.

Estruturados a partir do projeto colaborativo, interdisciplinar e processual, os resultados decorrentes dos workshops, palestras e investigações ocorridas no entorno do projeto colaborativo 24 Horas: Uma Linha na Cidade (Casa da Memória e POCS) irão integrar o banco de imagens e dados, acervo da Casa da Memória, inaugurada em julho de 2008.

0 Projeto Colaborativo Casa da Memória - Núcleo da Memória Audiovisual da Paisagem Humana de Paranapiacaba, integrante do Museu a Céu Aberto é uma realização da Subprefeitura de Paranapiacaba e Parque Andreense, da Prefeitura de Santo André, Estado de São Paulo, Brasil.

\section{Imersão e Residências Artísticas}

\section{Lugares da Memória e Memórias do Lugar}

Artista Residente. Frederico Dalton: Multimidia da Figura Humana. 17 a 21 de dezembro 2007.

\section{Realização - Rede Nacional de Artes Visuais - FUNART} Casa da Memória - Museu a Céu Aberto

Apoio: Sub-Prefeitura de Paranapiacaba e Parque Andreense Prefeitura de Santo André

\section{Objetivo e Conteúdos}

Fotografia, Desenho e Performance: Explorar o conceito de "Paisagem Humana".

Localizar e fotografar objetos carregados de memória com participação dos moradores. Os resultados dos registros fotográficos serão incorporados no acervo da Casa da memória, envolvendo simultaneamente a produção visual de artistas e não-artistas. 
Encenar coletivamente uma fotografia reproduzindo o "instante signficante" na vida e memória da comunidade na sua relação com o território.
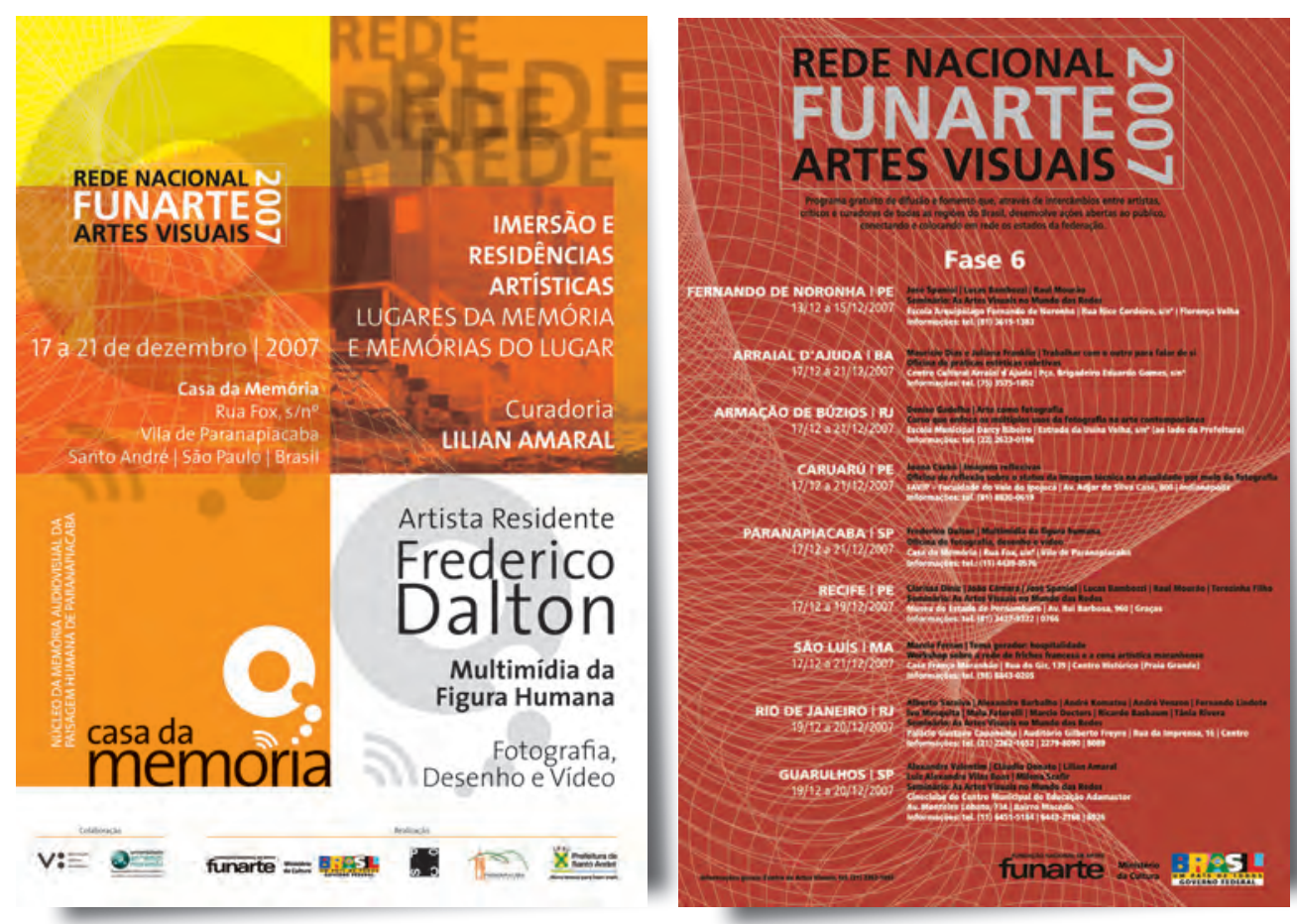

Figura 32 - Casa da Memória integra a Rede Nacional de Artes Visuais da FUNARTE, 2007

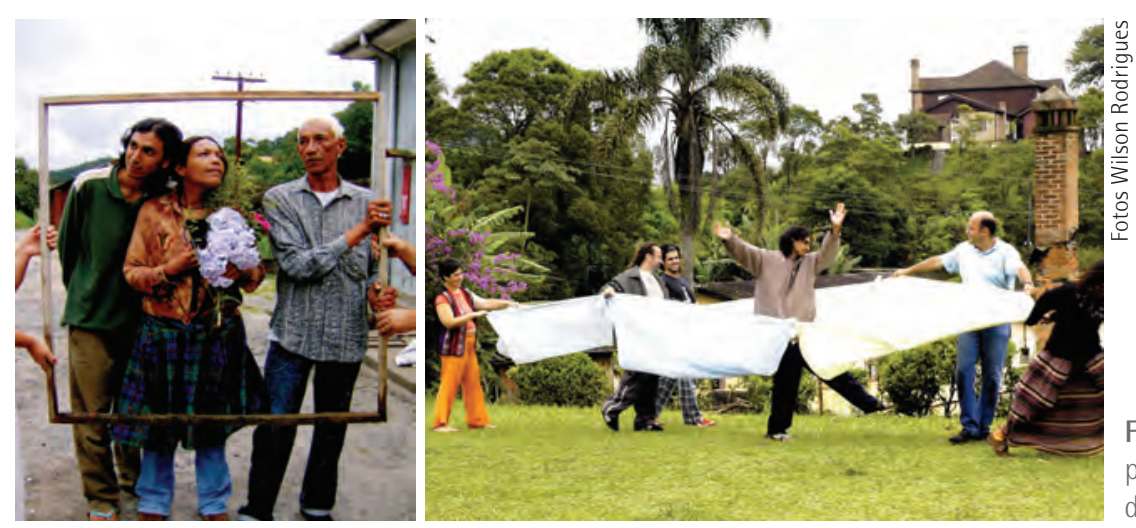

Figura 33 - Atividades envolvem articulações e criações performativas no território e relações interpessoais com base na dramatização das memórias individuais e coletivas. 


\section{Avaliação Coletiva}

Albina Cusmanich Ayala. Bióloga, Agente da Memória, Moradora de Paranapiacaba. Dezembro 2007.

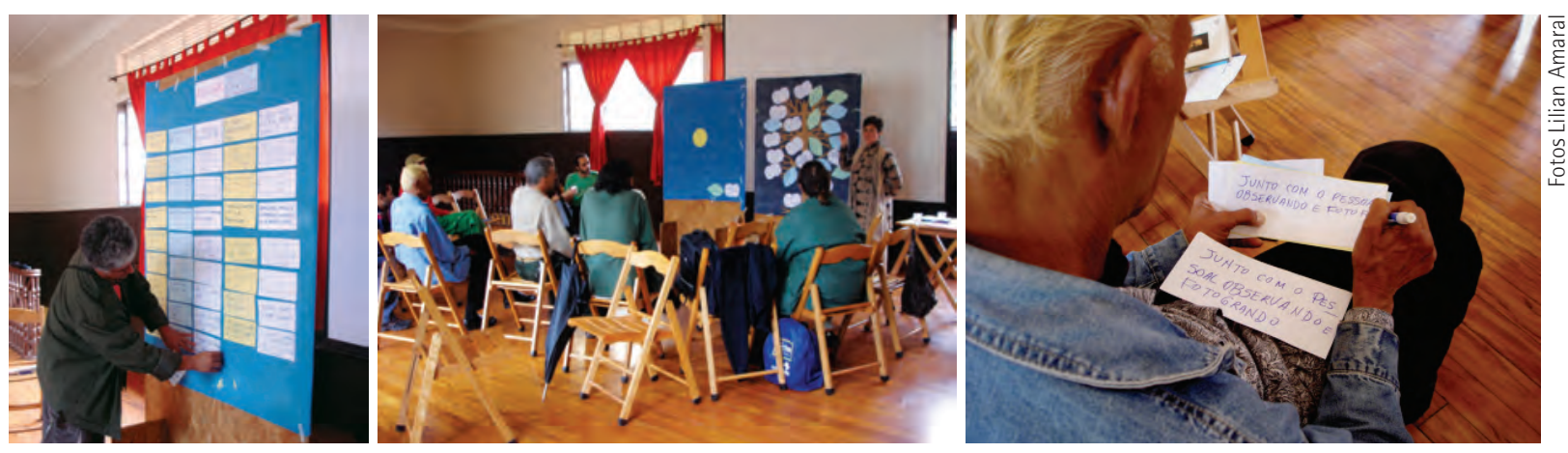

Figura 34 - Atividades de Avaliação Coletiva

0 processo de avaliação apontou aspectos significativos no que se refere às formas de atuação compartilhada, aos processos de agenciamento colaborativo adotados no projeto, com base em intensa participação e mobilização. 0 atual estágio de composição de Conselho para a Casa da Memória e sua autogestão foram aspectos debatidos em profundidade ao longo do processo de avaliação, garantindo, junto ao poder local, poder decisório e representação no Conselho Gestor da Vila de Paranapiacaba, composto pelos moradores, Agentes da Memória. 


\subsection{ARTE EM PROCESSO: O DOCUMENTÁRIO COMO PLATAFORMA PARA CONSTRUÇÃO DE NARRATIVAS COLETIVAS}

Imagem complexa: amálgama que compõe uma textura dotada de densidade e volume. 0 vídeo permite a pregnância em que pintura, fotografia, cinema e arquitetura constituem um corpo. Esse entrelaçamento de paisagens e o traçado da cidade de imagens.

Nelson Brissac Peixoto. Paisagens Urbanas, 1996

A investigação videográfica permeou os trajetos da presente investigação, que se fundamenta na concepção ampliada da arte como experiência e na narrativa documentária, tendo os lugares da cidade - reais e imaginários - como suporte para criações coletivas envolvendo artistas e não-artistas em processos abertos.

Aspectos relativos à articulação entre linguagens e áreas de conhecimento imbricados à prática crítica - formação artística, curatorial, mediadora e documental - confluiram para definição da concepção do acervo audiovisual da Casa da Memória - práxis aberta e contínua que aproxima e estabelece diálogo entre o documentário e as artes visuais contemporâneas. Estrutura-se e estabelece inter-relações com processos coletivos e colaborativos, tendo como base a produção de vídeos documentais.

Em vez da função clássica de "fazer ver", o documentário na atualidade produz uma revisão dos modos de ver, apenas entrevendo a realidade, distinguindo-a de maneira parcial, subjetiva ou imperfeita. Esse estado errante do documentário contemporâneo - que tramita entre o cinema e a tevê e ganha impulso nas artes visuais e na internet - articula registros de ações artísticas, negociações no campo da alteridade. Dar voz ao outro, 
ceder a câmera ao outro, são atitudes de projetos documentais com variáveis antropológicas. A ausência do autor no ato da filmagem é outra condição que valoriza e intensifica a expressão do outro.

A narrativa documentária contemporânea faz uso de um ou mais protocolos documentais (entrevistas, conversas, registros de cenas reais, narração de história verídica, testemunho pessoal etc.), ou desmonta os mesmos protocolos e reinventa dramaturgias. Evidencia ambivalências da atual condição documental, construída a partir do diálogo entre a voz do documentarista e a voz do outro que se sobressai nesse tipo de trabalho com maior comprometimento de observação e articulação de contextos culturais e sociais, evidenciando uma questão que parece estar por trás de todo impulso documental contemporâneo: a negociação entre identidades.

Mas o documentário não é a obra, está muito próximo da condição de certos registros de ação: o vídeo não é a obra quando não abarca toda a complexidade da experiência gerada pelo acontecimento. Talvez a maior diferença entre o registro de processos e o documentário seja a impossibilidade de o registro compartilhar da vocação transcendente do acontecimento. Ao aproximar o documento, a documentação e o documentário, o que se pretende é identificar atritos, potências e correspondências entre campos.

"MultipliCity"- A Metrópole como experiência imagética, vídeoinstalação, 2006/2007 trata da imagem hodierna e das abordagens teórico-práticas relativas ao pensamento eletrônico e formas de comunicação e informação contemporâneas. Sintetiza diversas práticas de arte pública desenvolvidas no interior do projeto processual Museu Aberto, configurando-se como um "Museu de Experiências Pessoais ".

0 vídeo "E no Meio Passa um Trem", realizado como requisito na formação de Agentes da Memória sob orientação de André Costa, 
documentarista e professor de cinema, no âmbito da constituição da Casa da Memória, estrutura-se a partir da investigação acerca da paisagem/experiência audiovisual de cada participante no contexto da Vila de Paranapiacaba, convidado a deter-se com uma câmera fotográfica e um gravador sonoro na busca da relação subjetiva e objetiva com o lugar, ativando e estreitando o sentido de apropriação e pertencimento. Concomitantemente realizados, o documentário "MemoryScapes/Paisagens da Memória", 2008, dirigido por esta pesquisadora e com a participação de moradores locais, de Agentes da Memória, técnicos e alunos do Curso de Cinema da Universidade Anhembi Morumbi, apresentam-se como resultados concretos das práticas interdisciplinares que adotaram múltiplos códigos e linguagens, métodos abertos ancorados neste estudo-intervenção, constituindo, no processo de construção colaborativa, o perfil do acervo do Núcleo da Memória Audiovisual da Paisagem Humana de Paranapiacaba.

Ao analisar a ação colaborativa, a produção artística e o meio videográfico, Christine Mello, pesquisadora, curadora de vídeo e novas mídias aprofunda a questão na seguinte direção:

0 vídeo passa a ser um campo desterritorializado e nômade de linguagem, figura entre diversas linguagens envolvidas no processo sígnico das novas tecnologias de comunicação, deixa de se apresentar como elemento de apreensão estética e funde-se de forma colaborativa a outras estratégias discursivas. No compartilhamento, as extremidades do vídeo ocasionam rupturas no estatuto do código videográfico. 0 vídeo deixa de ser visto eminentemente como um produto audiovisual e passa a colaborar em funções discursivas mais abertas, gerando situações de compartilhamento audiovisual com ações artísticas de outra escala, complexidade, dimensão e natureza ${ }^{26}$.

A escolha das imagens, temas e depoimentos tratados, a trilha sonora e aspectos de edição, apresentação, montagem, exposição
26 Mello C. Extremidades do Vídeo. São Paulo : Editora Senac São Paulo, 2008, p. 197-198. 
e difusão estão na base conceitual e metodológica deste tipo de prática artístico-crítica coletiva que incide na esfera pública a partir da valorização da subjetividade, do olhar e experiência individual, singular, para articulá-la, ressignificá-la, amplificá-la ou mesmo transformá-la no âmbito coletivo.

Se partilharmos do pressuposto de que o espaço tem um sentido vital para o ser humano, podemos entender que criar a situação de vivenciá-lo (a escultura no campo ampliado, a videoinstalação, a obra interativa) e não somente contemplar um espaço apriorístico, é levar esta ideia do campo da arte ao campo da experiência, postulando uma atitude ativa diante do espaço da vida social.

\subsubsection{Expansão de fronteiras - 0 estatuto da imagem documental na contemporaneidade}

MultipliCity se constitui como projeto-processo no qual se imbricam experiências performáticas e videográficas desenvolvidas a partir de práticas artísticas colaborativas (situ-ações, experiências no espaço público) realizadas em diferentes contextos urbanos, entre os quais destacam-se Avenida Paulista, São Paulo (vídeo Olho Canibal, 1998); Heliópolis, São Paulo (vídeo Alegoria do Caos, 2000) e Paranapiacaba, Santo André (vídeos Cidadeldentidade Humanscape, 2001).

Embora os trabalhos estejam focados no outro e sobre o outro, estabelecendo situações de encontro, constituem-se, em grande parte, em processos interativos e colaborativos que apresentam similaridades e dialogam com o assim chamado "New Genre Public Art" (Novo Gênero de Arte Pública), que se desenvolveu, sobretudo, nos Estados Unidos a partir da década de noventa, em direção às atuais abordagens da Arte Relacional e seus 
desdobramentos, fundadas nas formas de convívio e experiência urbanas. São práticas poéticas que reúnem ética e estética. Processos que podem ser entendidos quase como performances, onde um grupo de pessoas se encontra e se aproxima e suas reações, sejam estas de ordem individual-psicológica ou coletivasocial, são documentadas de forma poética, notadamente em vídeo, resultantes de intervenções urbanas e humanas.

MultipliCity, experiência em DVD elaborada como laboratório para realização de videoinstalação, estrutura-se a partir da noção do espaço urbano contemporâneo e sua fragmentação. Do ponto de vista formal, constitui-se a partir de cinco planos imagéticos distintos e justapostos, sangrados na tela/suporte e explodidos no espaço expositivo.

Convoca a uma apreensão de espacialidades simultâneas problematizada pela velocidade, transitoriedade, sensorialidade e efemeridade. Em MultipliCity a conceituação se dá a partir de um espaço múltiplo, fluido, mutante, afetivo: o dentro e fora confluentes. 0 sentido de aceleração e vertigem potencializase e figura na contraposição estabelecida entre planos-imagens que simulam o espaço arquitetônico convencionado para a experiência de fruição estética - o cubo branco, ou seu correlato contemporâneo, a caixa preta - a partir do qual uma imagem central em preto e branco, semifixa, cria contrapontos com imagens cuja relação cromática, espaço-temporal diferem sucessivamente.
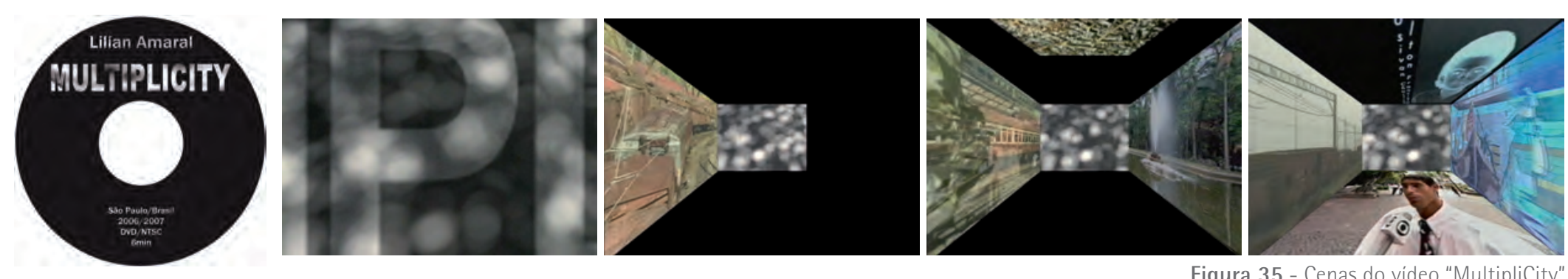

Figura 35 - Cenas do vídeo "MultipliCity" 
No contexto da Avenida Paulista, por exemplo, o sentido de fragmentação é dado pela multiplicidade, saturação, velocidade, intensificado com a criação de micropalimpsestos que aproximam a linguagem ao videoclipe. Cortadas, sobrepostas, imagens de Heliópolis são contrapostas às da Avenida Paulista e sucessivamente a outras que sugerem uma desaceleração radicalizada, como os registros referentes à vila ferroviária de Paranapiacaba, fundada no século XIX.

A relação com a fotografia e o uso de dispositivos como o slowmotion propiciam o sentido de suspensão do tempo, que contrasta com a decorrente vertigem resultante da aceleração-desaceleraçãosobreposição das imagens relativas à experiência urbana na megalópole contemporânea.

Refletir o meio videográfico não apenas como uma tecnologia representacional, mas também como uma linguagem que associa estratégias de simultaneidade do tempo presente, constitui um modo de investigá-lo em seus mecanismos de expansão, tanto em seu caráter processual e em suas potencialidades temporais quanto em sua característica de estar entre os diversos dispositivos e ambientes. Diz respeito ao seu caminho poético de buscar as fronteiras da linguagem e as margens que expande, entre as diversas outras áreas. Trata-se de abordar um meio instável, impermanente, transitório, que introduz a ideia de fluxo midiático no universo da arte e que é capaz de dialogar hoje com a ampla gama de procedimentos criativos relacionados aos meios tecnológicos e às experiências da arte pública contemporânea e suas derivações.

Uma das discussões que tem ocupado o cenário do debate contemporâneo trata da maneira pela qual as categorias do espaço e tempo vêm sendo repensadas sob o paradigma da tecnologia da informação. Trata-se de espaços de fluxos e em tempo real ao se referir a esta nova dimensão espaço-temporal do mundo contemporâneo. Parece-nos que, independentemente do nome que possamos dar a esta nova dimensão, estamos de acordo que as novas tecnologias da informação trouxeram modificações profundas na maneira pela 
qual nos relacionamos com o espaço e o tempo, produzindo debates contundentes no campo da estética e da arte contemporânea.

Nesse contexto, em que a imagem "perde cada vez mais seus traços materiais, a sua corporeidade, a sua substância, para se transfigurar em alguma coisa que não existe senão em seu estado virtual, desmaterializada em fluxos de corrente elétrica"27, o processo de desmaterialização empreendido pelo vídeo revela um grande legado no que tange à temporalidade e a uma diversidade de experiências que contribuem e influenciam os campos perceptivos possibilitados pela arte nos dias atuais.

0 vídeo assimila todas as outras imagens e permite a conexão entre os suportes, sendo, portanto, o lugar por excelência da passagem. 0 cinema extrapola a tela para as formas espaciais da instalação, assim como a fotografia que sai do quadro para permitir a adaptação da imagem ao espaço circundante. 0 mundo das imagens e o mundo dos objetos deixam de se opor e operam fusões. A mixagem eletrônica substitui a montagem no interior da imagem e as superposições estabelecem outro modo de conexão, propriamente visual, não verbal. Passa-se de uma imagem à outra através de um evento imagético.

\subsection{DERIVAÇÕES DA ARTE PÚBLICA CONTEMPORÂNEA EM CONTEXTOS INTERCULTURAIS IBEROAMERICANOS}

0 papel do lugar é determinante. Ele não é apenas um quadro de vida, mas um espaço vivido, isto é, de experiência sempre renovada, o que permite, ao mesmo tempo, a reavaliação das heranças e a indagação sobre o presente e o futuro. Milton Santos, 2000.
27 Machado A. 0 quarto iconoclasmo e outros ensaios hereges. Rio de Janeiro : Rios Ambiciosos, 2001, p.35 
A presente discussão propõe analisar o lugar da arte no âmbito da esfera pública contemporânea a partir da diluição e do deslocamento do objeto para o campo da experiência estética, tendo o tempo se convertido em matéria artística.

Transitar entre a autonomia e a instrumentalização parece ser um dos dilemas enfrentados pela arte que incide em dinâmicas sociais, prática contemporânea derivada da arte pública e suas recentes hibridizações, como "novo gênero de arte pública", "arte contextual", "estética relacional", entre outras reconfigurações. Tais questões podem iluminar um debate sobre as práticas críticas como campos de ação processuais e colaborativos apontando para renovadas formas de comunicação, apropriação e pertencimento. Objetiva-se investigar os modos de fazer artísticos compartilhados em rede, os processos de transformação no território deles decorrentes e implicações políticas no tecido social.

0 atual confronto com a modernidade, a quebra de fronteiras entre suportes, linguagens e áreas do conhecimento, além da aproximação entre camadas da cultura, permite que a arte engendre lugares de novas experimentações estéticas, acopladas às tensões sociais existentes no entorno do artista. Se a relação entre arte e estética sempre acompanhou a produção artística, atualmente, a reunião entre elas pode se configurar como uma dimensão básica do fazer artístico.

A supressão das fronteiras tradicionais que ordenavam a produção, moradia e a experiência provocou uma profunda mudança na espacialidade e temporalidade que experimentamos cotidianamente. A globalização, com o crescimento das trocas internacionais de informação e comércio, fluxos intensos de produtos e, sobretudo, de conhecimento, levou a uma profunda transformação na organização da produção econômica, dos espaços urbanos e das relações entre as pessoas. Conforme muitos críticos da cultura e teóricos do urbanismo têm alertado, a crescente indiferenciação e desparticularização dos espaços, 
espetacularizados pela atual globalização da tecnologia e das telecomunicações para acomodar a ordem capitalista em expansão, vem exacerbando os efeitos de alienação e fragmentação na vida cotidiana.

0 que tradicionalmente entendíamos como cidade era um lugar passivel de ser equacionado e percebido a partir da experiência diária. Tratava-se da cidade que estava ao alcance da experiência, cujo traçado e monumentos eram referências legiveis para o habitante urbano - o passante, o morador. A ideia de o monumento configurar o espaço urbano e orientar as possibilidades de sua leitura pertence a um momento histórico definitivamente superado. A cidade converteu-se em superficie opaca, inacessivel, principalmente porque ganhou uma configuração que não se dá mais a esses dispositivos de percepção. A cultura ocidental entrou em colapso com o crescimento econômico caótico, a desigualdade social, a reconfiguração permanente e cíclica da cidade por outros investimentos desorganizados.

Um dos resultados desses processos complexos que nos escapam à compreensão é o colapso da experiência individual, resultando na introdução crescente de estratégias abrangentes de análises e mapeamentos das situações. Tal colapso vai ter um impacto muito grande na produção artística. A grande conquista da arte contemporânea foi compreendê-la para além do objeto artístico e a produção que dela resulta tem relação com o entorno - e esta relação implica uma nova atitude na percepção. Exige um observador atento e ativo que se desloque, investigue, procure compreender a nova configuração estabelecida pela arte e seja capaz de entender a natureza ativa da arte no espaço.

Toda a arte, especialmente a feita dos anos sessenta para cá, desenvolveu esse grande dispositivo, criando um campo que hoje é nomeado de campo expandido, no qual a arte, seu entorno e o observador estão implicados numa relação dinâmica. A arte passou a absorver uma ideia mais ampla de espaço, entendido 
como aquela configuração territorial demarcável pela experiência e também uma série de elementos de ordem político-institucionais, econômicos, sociais e históricos.

Ao se defrontarem com a complexidade que caracteriza a multiplicidade de elementos que determinam tal espaço, os artistas incorporaram essas inquietações como parte de um repertório comum, fazendo das condições do seu trabalho, o próprio trabalho. 0 artista converteu-se em agenciador de investigação, uma vez que os elementos acerca das condições nas quais sua produção opera são determinantes para sua prática artística. Observa-se uma completa inversão de papéis, convencionalmente atribuídos à pesquisa, que deixa de ser uma coisa a priori ou a posteriori, passando a ser intrínseca ao processo de criação. A criação é um processo na sua melhor forma, no qual cada vez mais o trabalho do artista é entendido, não como uma corporificação final exposta e definitiva, mas como uma mecânica de continuação constante, que se desdobra em inúmeros inputs e vai se fazendo pela assimilação de informações múltiplas e infinitas dos entornos nos quais se inscreve.

A fronteira hodierna que dirime a arte da pesquisa é muito mais tênue e o artista ganha perfil de pesquisador. No momento em que esses novos procedimentos criativos se consolidam, a demanda por interlocução investigativa se amplia e passa a ser de outra natureza; ela se dá em função de processos criativos e nem tão somente pela avaliação de processos já realizados. As mais recentes formas de organizações institucionais buscam criar maior porosidade com relação ao que está ocorrendo em seu entorno, bem como estabelecer mecanismos de cooperação com esses processos vivos de investigação e criação.

Nessas circunstâncias abertas surgem determinados projetos - POCS, Museu Aberto, IDENSITAT e Madrid Abierto - nos quais nos deteremos mais adiante, para aprofundar a compreensão da expansão de limites tensionados pela arte contemporânea, 
propositores de espaços de encontro entre arte e vida, estética e política e entre artista e sociedade.

\subsection{TRANSVERSALIDADES INTERCULTURAIS: PROJETOS PROCESSUAIS, MUDANÇAS EPISTEMOLÓGICAS}

Uma das características comuns em relação aos projetos e práticas artísticas em discussão é a duração e dilatação do tempo. 0 tempo mesmo se converteu em conteúdo. Nicolas Bourriaud nos informa, ao refletir sobre a estética relacional e seus contextos, que

(...) a produção de uma subjetividade que auto enriqueça de forma contínua o mundo, define de maneira ideal as práticas dos artistas contemporâneos que criam e colocam em cena dispositivos de existência que incluem métodos de trabalho e modos de ser; em lugar dos objetos concretos que delimitavam até agora o campo da arte, utilizam o tempo como um material (BOURRIAUD, 2006:130-131).

Seguindo esta linha de argumentação, em diálogo com as ideias de Bourriaud, tomamos partido do que se pode nomear como especificidade relacional. Mais do que afirmar diferenças, as práticas site-oriented atuais, especialmente analisadas por Mwon Kwon em seu artigo One place after another: notes on Site Specificity ${ }^{28}$ herdam a tarefa de demarcar a especificidade relacional a partir de negociações das tensões dos pólos distantes e das experiências espaciais; endereçam-se às diferenças das adjacências e distâncias entre uma coisa, uma pessoa, um lugar, um pensamento, um fragmento ao lado do outro, mais do que evocam equivalências por meio de uma coisa após a outra.

Diante desse panorama que tem caracterizado o lugar da arte
28 Kwon M. One place after another: notes on Site Specificity. EUA: Revista October 80, EUA, 1997, p. 88. 
contemporânea, seu embate com as diversas temporalidades na implicação dos modos de fazer artístico que operam processual e colaborativamente, evocamos algumas ideias do campo da geografia humana propostas por Milton Santos (2000), nas quais "as horizontalidades são zonas de contiguidade que formam extensões contínuas", configurando o que François Perroux denomina de "espaço banal", o que corresponderia ao espaço de todos: empresas, instituições, pessoas; o espaço das vivências. Em tal espaço, conforme o geógrafo brasileiro,

(...) todos os agentes são, de uma forma ou de outra, implicados, e os respectivos tempos, mais rápidos ou mais vagarosos, são imbricados. (...) Em tais circunstâncias pode-se dizer que a partir do espaço geográfico cria-se uma solidariedade orgânica, o conjunto sendo formado pela existência comum dos agentes exercendo-se sobre um território comum. Nas horizontalidades funcionam, ao mesmo tempo, vários relógios, realizando-se, paralelamente, diversas temporalidades (SANTOS, 2000: 111-112).

Desta forma, temporalidades e territorialidades operam um constante tensionamento entre espaços de fluxo e espaços banais, resultam na readaptação às novas formas de existência. Entendemos que tal processo é também aquele pelo qual uma sociedade e um território estão sempre à busca de um sentido e exercem, por isso, uma vida reflexiva. Assim, ainda segundo o autor:

(...) o território não é apenas o lugar de uma ação pragmática, (...) comporta, também, um aporte da vida, uma parcela de emoção, que permite aos valores representar um papel. 0 território se metamorfoseia em algo mais do que um simples discurso e, constitui um abrigo (SANTOS, 2000: 115).

No que se refere à relação entre território e experiência, podemos encontrar no campo da geo-história uma possíve 
relação dialética entre espaço e tempo, superando, assim, a visão tradicional que predominou até pelo menos o início do século $X X$, a qual encarava o espaço geográfico como estático, como mero "marco natural" para a ação humana. A partir de Fernand Braudel, contudo, os campos disciplinares da história e da geografia se aproximam, possibilitando o que o próprio autor chamava de "tempo geográfico" e Alain Musset denomina de "geografia de longa duração" (MUSSET, 2009). A realidade atual é mais facilmente compreendida ou apreendida a partir da relação espaço-tempo ou da "geografia de longa duração", que permite conclusões muito mais pertinentes sobre essas diferentes realidades geográficas e urbanas que caracterizam a paisagem ibero-americana e nos ajuda a compreendê-las no momento presente. A geo-história, em outras palavras, possibilita entender a cidade atual, tanto em sua dimensão social quanto espacial, a partir do nosso olhar sobre a cidade do passado.

$\mathrm{Na}$ noção de tempo que nos propõe Walter Benjamin o passado está aberto porque nem tudo nele se realizou. 0 passado não está configurado somente pelos feitos, quer dizer, pelo "já realizado", mas pelo que está por acontecer, por virtualidades a realizar, por sementes dispersas que na sua época não encontraram um terreno adequado. Há um futuro esquecido no passado que é necessário resgatar, redimir, mobilizar. Daí que para Benjamin, o "tempo-agora" seja todo o contrário de nossa atualidade, isto é, a faísca que conecta o passado ao futuro.

Com base nas contribuições destes variados campos, entende-se que somente as práticas culturais que tenham essa sensibilidade relacional podem tornar encontros locais em compromissos de longa duração e transformar intimidades passageiras em marcas sociais permanentes. 


\subsection{CONFIGURANDO REDES E O TRABALHO COLABORATIVO NO CAMPO DAS ARTES VISUAIS: REDES SOCIAIS, MEMÓRIA, ARQUIVO E ACESSO}

0 mundo da mídia (em mobilidade) se expande. Fotografar, filmar, enviar mensagens gravadas, mensagens de texto. Receber filmes, fotos, clipes, notícias, avisos. 0 início do século XXI está preparando outra mutação na maneira como as pessoas se comunicam. 0 que se pode observar é que a revolução real na computação (sem fio em especial), não é apenas comercial ou tecnológica, mas também social.

Os processos de colaboração estão presentes por toda a parte em nossa sociedade. Na esfera da comunicação, as redes digitais popularizam as ações colaborativas, sendo o fenômeno das comunidades virtuais e das redes sociais seu foco marcante. Já no âmbito do trabalho, que hoje está fortemente marcado pela produção e troca de conhecimentos, pela comunicação e, sobretudo, pelo investimento afetivo, encontramos um forte apelo às redes de colaboração.

Fazer redes tornou-se uma prática que está ecoando por todo o mundo empresarial, nas esferas dos governos e também no Terceiro Setor. Há mais de uma década o conceito de inteligência coletiva passou a ser sinônimo dessa noção de colaboração, de fazer redes, tanto na comunicação quanto no campo do trabalho.

Abre-se espaço para uma discussão processual sobre dimensões do conceito de inteligência coletiva e dá-se abertura a uma nova dimensão, a micropolítica, onde ele passa a ser entendido como resistência aos processos de alienação do capitalismo cognitivo.

A presença da Internet e as decorrentes redes sociais tem potencializado as formas de relacionamento e diálogo entre coletivos, grupos de artistas, pensadores e sociedade. Uma rede de agenciamentos que hoje é constituída por afinidades, orientando estratégias entre artistas e instituições para o desenvolvimento de 
práticas colaborativas que envolvem processos, e, por conseguinte, a prática da educação. Nesta direção, pensar a experiência, a memória e os arquivos como dispositivos artísticos e de mediação cultural vem ganhando espaço nos debates atuais, de forma a ampliar o acesso à informação e ao conhecimento gerado coletivamente.

Debater sobre as emergências coletivas e redes ante situações específicas, as quais constituem espaços autônomos de crítica e ação construtiva, podem contribuir para a análise dos mecanismos que tornam tais práticas como trabalhos em rede que cedem lugar a outras formas de entendimento da produção cultural e do conhecimento contemporâneo. Neste sentido, questiona-se o lugar das disciplinas e âmbitos oficiais onde se inscrevem discursos de produção cultural e cognitiva herdados da modernidade e como é possivel esgotar tais discursos produtivamente, ou seja, que oportunidades são factíveis em cada contexto.

A ecologia própria de cada projeto coloca em questão os meios e recursos de que dispõem os coletivos e de que maneira os projetos são desenvolvidos para tornarem-se eficazes e sustentáveis em seu campo de atuação. Problemas como circulação e distribuição do trabalho coletivo e o objetivo de assumir futuros nós e multiplicadores dos projetos nos respectivos contextos, implicam que seu trabalho de intervenção política deveria apontar para sua sustentabilidade.

Frente a tal contexto cabe refletir sobre a forma com que a arte tem se apropriado deste conhecimento e como a sociedade tem dele se beneficiado. De que maneira a formação de redes sociais tem atuado no desenvolvimento da arte e da educação? Como promover a visibilidade de projetos processuais que se aproximam e se imbricam com a prática pedagógica e por atuarem em outra escala temporal, demandam novos modos de registro e difusão? Estas são algumas das questões com as quais nos deparamos na contemporaneidade, especialmente no que se refere aos novos 
modos de fazer, documentar, comunicar e preservar as memórias e histórias de ações que envolvem processos estéticos de longa duração, variadas estratégias inter e transdisciplinares, materiais e dispositivos de atuação artística colaborativa.

Ao considerar a emergência em torno de tais reconfigurações no campo da política cultural, das inserções no tecido social e implicações no panorama crítico contemporâneo, entendendo a esfera de complexidade que deste contexto emerge, enfatiza-se a necessidade de um debate aprofundado no qual a interterritorialidade de meios, contextos e processos de transformação sejam contemplados por diferentes e múltiplos olhares entrelaçados.

A partir da última década do século $X X$, observa-se 0 deslocamento das práticas artísticas em direção ao campo da estética relacional abrindo espaço para a arte pública reconfigurada em torno de ações compartilhadas, enunciando-se a crítica ao PósModernismo e uma reação aos desígnios econômicos e de mercado colocados em pauta pela globalização. A arte passa a articularse em uma instância para além das instituições, expandindo-se para o âmbito das cidades e intensifica-se a busca de espaços de interlocução social pelos artistas.

Parte-se da ideia de que a arte pode ser um fator de inovação nos processos de transformação da cidade, posto que é capaz de fazer emergir a criatividade social latente e desdobrar-se através de ações coletivas. Mas como a arte se relaciona com os processos de transformação urbana e social? Que papel e função tem os processos de participação? Como se pode ativar a criatividade social em um entorno determinado, assim como desenvolver processos criativos que a médio e longo prazos incidam em um entorno local? Como se pode participar de âmbitos de ação coletiva através de processos criativos? A transformação da cidade está aberta a projetos? Que relação direta existe entre políticas culturais e planejamento urbano? Podem os contextos locais participar do discurso cultural global? 
Estas questões têm instigado debates, aproximando arte contemporânea, inteligência coletiva e cidades criativas, em pauta nos encontros e discussões urbanas, artísticas e culturais atuais nos âmbitos nacional e internacional. Tal constatação parte da observação e participação em contextos confluentes, como os debates em torno do Seminário Internacional Porto Alegre, Cidade Criativa, no qual incidimos na condição de curadora setorial no campo de prática das Artes Visuais, ocorrido por iniciativa do Santander Cultural e Prefeitura Municipal de Porto Alegre, em setembro de 2009, o III Simpósio Internacional de Arte Contemporânea do Paço das Artes / Secretaria de Estado da Cultura de São Paulo, realizado em outubro de 2009, ou ainda, - Encontro Internacional Mapeamentos Socioculturais Território e Diversidade, realizado por iniciativa da Agência Espanhola de Cooperação Internacional e Instituto Polis, no SESC, São Paulo, em outubro de 2009, o projeto Desafios Contemporâneos, organizado pela FUNARTE São Paulo, no qual enfatiza a discussão acerca do papel do artista pedagógico como mediador, em novembro de 2009, assim como o Encontro Internacional Arte e Transformação no Território, organizado pelo SESC Santo Amaro, São Paulo, em setembro do mesmo ano, do qual fui igualmente curadora.

De um lado, exercita-se a conquista de novos espaços, ao mesmo tempo em que se combate a aceleração e a amnésia por meio de práticas que passam a considerar outras relações e novos territórios, nos quais ganham espaço artistas que operam articulações em redes, valem-se da noção de inteligência coletiva, arquivos, e, portanto, de uma nova abordagem crítica frente aos museus, enfim, novas formas de agenciamento no campo da arte, tais como os engendrados por coletivos e trabalhos colaborativos.

Vivenciamos uma profunda transformação da experiência do tempo, absorvido pela entropia informacional e desestabilizado pela velocidade crescente dasinovações tecnológicas o atual boom 
29 Huyssen, A. Memórias do Modernismo. Rio de Janeiro: Ed. UFRJ, 1996. Este livro reúne textos de dois livros de Huyssen: After the great divide: Modernism, mass culture, postmodernism, e Twilight memories: Marking time in a culture of amnésia, Columbia University, New York, 1995.

30 Williams R. Marxismo e literatura. Barcelona: Península, 1980, p. 143-150. da memória como uma de suas mais eloquentes manifestações. Observamos o retorno da história como experiência.

Andrea Huyssen ${ }^{29}$ rastreou esse boom ao longo das últimas décadas: crescimento e expansão dos museus, restauração dos velhos centros urbanos, auge da novela histórica e dos relatos biográficos, moda "retrô" em arquitetura e vestimentas, entusiasmo pelas comemorações, auge dos antiquários, o vídeo como dispositivo de memorização e, inclusive, a conversão do passado do mundo - e não somente o que coletam os museus - em banco de dados. Temos que incluir, ainda, neste catálogo de referências do memorialismo atual dois dos grandes debates políticos do final do século: o dos direitos das minorias étnicas, raciais, de gênero etc., e o da "crise da identidade nacional", ligada tanto ou mais que o processo de globalização à explosão das memórias locais e grupais.

0 maior deslocamento do museu tradicional é produzido pela nova relação entre Museu e Cidade: assistimos à restauração de bairros inteiros convertidos em espaços culturais turísticos. 0 atrativo de muitas cidades reside hoje na quantidade e qualidade de seus museus e a pressão que isso representa para que façam parte da indústria do turismo e suas múltiplas formas de recordação: livros, cartazes, vídeos, cartões, roupas, artesanatos. Um museu investigador do que no passado há de vozes excluídas, de alteridades e "resíduos", no sentido que dá a esse conceito R. Williams ${ }^{30}$, de fragmentos de memórias esquecidas.

No limiar de completarmos a primeira década do século XXI transparece a urgência de repensar o sistema da arte, as novas configurações de espaço e tempo, a circulação, difusão e produção cultural, considerando-se a atual crise econômica e a força das imagens da comunicação e da mídia no mundo da cultura visual contemporânea.

Neste sentido, cabe pensar de que maneira podem as instituições criar novos modos de ação frente à crise econômica 
agora imposta, assim como falar em economia criativa com referência à cultura e à arte contemporânea? É possível, ainda, falar em micropolítica e sustentabilidade? Quais as prováveis saidas para as artes e seu sistema? No que tange à indústria cultural, qual o lugar dos museus e os espaços da arte em consonância com a visão fluida que caracteriza o nosso tempo? Quais as estratégias que os espaços culturais e os artistas podem adotar frente às situações de crise? Qual o papel da arte na vida urbana contemporânea, considerando os processos acentuados pelo nomadismo e deslocamento irreversiveis da população mundial em direção às grandes cidades? Qual a perspectiva de vida qualificada nas metrópoles que se converteram em espaços privatizados e esvaziados de sentido público?

\subsection{ARTE E ESFERA PÚBLICA CONTEMPORÂNEA: PANORAMA DE MUTABILIDADE}

Encontramo-nos em uma fase de transformações culturais e das artes comparável, em sua extensão e profundidade, à transição que tinha lugar entre finais do século XVIII e meados do século XIX. 0 processo decisivo dos últimos anos no universo das artes é a formação de uma cultura diferente da moderna e de suas reverberações pós-modernas.

Um sinal particularmente eloquente deste universo é a proliferação de iniciativas de artistas destinados a facilitar a participação de grandes grupos de pessoas muito diferentes em projetos onde se associam a realização de ficções ou de imagens com ocupação de espaços locais e a exploração de formas experimentais de socialização. Estamos ante novas ecologías culturais $^{31}$. Tais projetos articulam ideias e instituições, imaginários e práticas, modos de vida e objetos, novas formas de intercâmbio e demais processos que a tradição imediata não permitia antecipar.
31 Termo que procede da antropologia cultural e que Reinaldo Laddaga reinscreve no âmbito da estética（LADDAGA, 2006). 
Em diálogo com recentes proposições de Reinaldo Laddaga no campo da estética, discutiremos projetos que aportam elementos para uma leitura desta reorientação no território ibero-americano das artes, desta transição em curso da qual o número crescente de artistas reage ao evidente esgotamento do paradigma moderno, onde podem criar uma iluminação e tensão que facilita a ativação de certa interação criativa.

Esta interação criativa oferece contextos nos quais os participantes podem estabelecer acordos gerais sobre procedimentos e resultados, onde alguns podem se colocar na posição de árbitros que apontam limites às atuações, à habilidade individual, ao conhecimento, no qual podem propor formas de preparação disciplinada e se acumular em histórias ${ }^{32}$.

Assim é como se produz a formação de identidades, onde se consolida uma ecologia cultural, em cujo interior, segundo Charles Tilly (2002), transações recorrentes entre unidades

(...) produzem interdependências entre lugares, transformam os entendimentos compartilhados no curso do processo e voltam a vastos recursos de cultura disponíveis em cada lugar particular através de suas conexões com outros lugares, por meio de uma organização espontânea que supõe a formação e a ativação de indivíduos que iniciam avanços ou demandas em suas escalas locais, mas que de alguma maneira os articulam com identidades de grande escala e lutas coletivas (TILLY, 2002:49).

Tais questões processuais foram debatidas e confrontadas por seus curadores e público no âmbito do Programa de PósGraduação "Aplicaciones del Arte en la integración Social Arte, Memória e Identidade" ocorridas na Universidade Complutense de Madrid, durante as Jornadas Abiertas Interculturales Miradas al Arte Público Contemporâneo - Geografías de la Inclusión y Transformación Social, em outubro de 2008. 


\subsubsection{Pesquisa e Produção Artística}

Discutir e implicar a pesquisa acadêmica e a ação da universidade no âmbito da cultura urbana tem sido o foco e o percurso de tais investigações em processo que procuram tensionar e ampliar os limites da prática investigativa diretamente relacionadas com a produção artística, seu diálogo com instituições culturais e as demandas sociais locais.

Uma profunda mutação no campo da percepção e produção da arte contemporânea tem evidenciado uma urgência outra, abrindo um campo extraordinariamente instigante frente às possibilidades e demandas geradas na articulação do binômio pesquisa/arte. Até pouco tempo atrás a pesquisa feita no campo da arte, de forma retrospectiva, tendia a manter, conservar, analisar e criticar o acervo da referida produção, ganhando, atualmente, novos contornos, na medida em que alguns fenômenos alteraram profundamente o quadro no qual se dá a compreensão do mundo em que vivemos e as respostas que tal produção pode hoje fornecer. Nessa transformação o papel da pesquisa tornou-se muito importante.

Curadas por esta autora, as Jornadas Abiertas Interculturales seguiram inspirando diálogos ibero-americanos no marco do projeto de concepção de ACVIC - Centre d'Arts Contemporàines, Vic en procés - realizado pela Universididade de Vic e Governo da Comarca da Catalúnya - Acciones Reversibles. Seminari sobre Art, Educació i Territori, em novembro de 2008, com curadoria de Ramon Parramon e Javier Rodrigo.

Naquele contexto intercultural foram apresentados, debatidos, expostos e publicados vários projetos de arte vinculados aos processos educativos e ao contexto social, com a possibilidade de gerar âmbitos de produção abertos à experimentação, ao intercâmbio e à produção de conhecimento com base na relação entre arte, atividade educativa e espaço social. Colocou 
em pauta como elemento mobilizador tanto aspectos de produção, de interação com o tecido social quanto de visibilidade e comunicação social dos projetos. Entre as experiências significativas em questão, foram aprofundados aspectos relativos à mediação no âmbito da Documenta XII, em Kassel - projeto Maiz que impulsiona diferentes projetos no contexto da educação e ativismo, comprometido com o campo da política cultural, entre o longo e o curto prazo. Focado nas relações (de poder) entre instituições artísticas e contextos locais é organizado por Carmen Mörsch, artista, investigadora e educadora, diretora do Instituto de Investigação para a Educação da Arte (IAE) na University of the Arts in Zurich, também pesquisadora do projeto de educação da Documenta XII em Kassel, 2007 e Rubia Salgado, co-fundadora e membro da equipe de Maiz. Uma abordagem que confere valor aos eventos ocasionais configura-se em torno do projeto WHAT, em Bruxelas, que constitui um espaço onde podem ocorrer situações, um lugar onde as coincidências são bem-vindas, onde inesperados encontros se produzem, um projeto de Kunstbank que desenvolve e possibilita que proliferem inesperadas raízes.

Entre as proposições abordadas no encontro, aponta-se especial destaque para a iniciativa de Tower Songs, uma plataforma interdisciplinar para o compromisso social e a prática artística, em Belfast, a partir de coordenadas críticas para uma comunidade baseada na produção cultural, sob direção de Ailbhe Murphy, artista visual que trabalha de forma extensa no contexto da prática colaborativa e comunitária e atualmente, na Universidade de Ulster, Belfast, investiga as práticas artísticas colaborativas e os processos de revitalização urbana na cidade de Dublin, sendo, também, co-fundadora de Vagabond Reviews.

Cascades Project é coordenado por Loraine Lesson, artista mencionada anteriormente no contexto da arte comunitária britânica e diretora de CSPACE, na University of East London, onde é investigadora convidada. Desde finais de 1970 vem 
desenvolvendo extenso trabalho junto a comunidades em torno de temas de revitalização urbana utilizando a arte e os media para incidir no domínio público.

A Associação AulaAbierta constitui-se como célula de investigação interdisciplinar convertida em experiência de extroversão acadêmica que articula pesquisa e arte, cultura e design na construção de uma comunidade de aprendizagem autogerida, composta e protagonizada por um grupo difuso de alunos, artistas, arquitetos, ambientalistas, antropólogos, vinculado à Universidade de Granada.

Entre as práticas de cooperação social e produção criativa em Sevilha, destacam-se as iniciativas sob a organização de Santiago Barber, artista visual que compartilha a partir da produção artística e comunicativa experiências com diferentes movimentos sociais no marco de processos de revitalização urbana e auto-organização social. Discutindo novos e velhos modelos de interpelação pública em instituições artísticas e culturais contemporâneas, marcos ideológicos e possibilidades críticas, Jesus Carrillo, investigador em arte e cultura contemporânea acirra o debate na atual condição de chefe do Departamento de Programas Culturais do Museu Nacional Centro de Arte Reina Sofía.

Ampliando a discussão intercultural apresentamos o projeto processual Museu Aberto - Casa da Memória: Núcleo da Memória Audiovisual da Paisagem Humana de Paranapiacaba, São Paulo, Brasil, único projeto representante do contexto latino-americano das artes participante do evento internacional que implica em processos colaborativos, focados em ações no território como espaço de interação social e prática artística crítica vinculada à paisagem cultural.

No âmbito do horizonte delineado pelas proposições em discussão, considera-se que a pedagogia produz experiências, conhecimentos e valores que temos ao nosso alcance, que estes recursos se veiculam através da produção artística e se relacionam 
com vivências decorrentes do contexto local, a produção de conhecimentos, valores e experiências podem gerar políticas culturais e aprendizagens baseados em processos coletivos.

Partindo deste ponto de vista e como campo de ação experimental, a relação arte-pedagogia não pretende em tais configurações educar através da arte nem para ela buscar novos públicos, tampouco pretende estabelecer diferenças entre o espaço institucional e o espaço de autogestão. Consiste em gerar situações nas quais se possibilite experimentar com a criação, a transmissão e o intercâmbio de conhecimentos e experiências, investigar a partir e com a produção artística, utilizando técnicas e meios que permitam que estas sejam comunicadas e veiculadas através da incorporação ou revitalização de dinâmicas sociais.

As linhas gerais sobre as quais se desenvolveram as propostas apontadas nos encontros realizados estruturaram-se sobre três elementos interconectados: os centros de produção e criação contemporâneos, o trabalho educativo e as redes de relação. Propõem articulações entre arte, pedagogia, instituições e agentes culturais imbricados no tecido social. Instituição e valor cultural não estão em posições antagônicas, mas lutam cada vez mais para conquistar âmbitos próprios, negociam para compartilhar espaços possíveis. Centros de criação contemporâneos e espaços autogestionados buscam espaços comuns. Este entrecruzamento, portanto, apresenta-se como possibilidade de colaboração, cooperação e trabalho em projetos educativos, não como fruto de uma tensão bipolarizada. Por esta razão, propõe em sua temporalidade uma progressiva hibridização entre projetos, instituições e centros de arte, analisando as ações reversíveis que derivam deste processo de intercâmbio em determinados contextos locais.

Entre os objetivos articulados por estas práticas dialógicas, destacam-se o conhecimento de possibilidades de atuação e 
abertura de um debate permanente sobre novas formas de política e produção cultural contemporânea e suas relações com as instituições sociais e educativas. Repensar as formas de produção de cultura e conhecimento contemporâneo sob o prisma das novas formas de educação cultural, cultura visual e arte/educação, possibilitam refletir sobre o novo papel dos centros de produção, colaboração, difusão cultural e centros de arte contemporânea em relação com o trabalho de desenvolvimento local, baseado na relação com coletivos e trabalhos em rede como forma de educação processual e política cultural em ação.

A partir de análises sistemáticas da produção e da articulação cultural como ação continuada, consideram-se estratégias de participação e negociação entre as instituições culturais, centros de produção e o público, questões que estão no centro da agenda dos processos de questionamento crítico em pauta no panorama de complexidade que configura a paisagem intercultural contemporânea.

Na investigação de doutoramento em curso, aponta-se especial relevo às matrizes contextuais locais em diálogo com experiências artísticas e interculturais ibero-americanas contemporâneas, confrontando os meios e os processos artísticos que envolvem mediações urbanas. Mediação de relações como ação e conhecimento pedagógico do/no cotidiano. Compreende-se o processo de mediação na direção apontada por Irene Tourinho, que o entende como sendo um

(...) processo alargado, estendido (...). A mediação configurase pela capacidade do mediador em criar formas de experimentar propostas colaborativas de aprendizagem. (...) a mediação como construção flexível e pragmática que pode contribuir tanto para a permanência como para a renovação e a transformação de modos de olhar, de fazer e de interpretar. Ambos fazem parte do processo de aprender e ensinar (TOURINHO, 2009: 271). 
Os projetos delineados a seguir operam e tensionam as práticas artísticas que articulam a concepção de tempo dilatado, desenvolvem processos de mediação que resultam em variados niveis de envolvimento e reconstrução no campo da arte, educação, esfera pública e política cultural.

POCS $^{33}$ - Project for open and closed space sculpture association-desenvolve propostasquequestionam eativam os espaços públicos através de convocatórias abertas desde 2003, resultam e fazem coincidir intervenções efêmeras no espaço público em diversas cidades em rede, como La Plata (Argentina), Medellin e Pasto (Colômbia), São Paulo, Rio de Janeiro, Niterói, Curitiba e Paranapiacaba (Brasil), Barcelona, Tarragona (Espanha) e Foggia (Itália). Entre as temáticas a partir das quais delineia sua linha de atuação aponta-se o ativismo e a ação coletiva, a experimentação, mediação, investigação, relações no espaço público, memória, meio ambiente, cotidiano, jogos, conflito, comunidade, homogeneização, motivação, alienação, ideologia, normas, moral, manipulação, liberdade, vínculo, hábitos, imitação. Estabelece diálogos e dispositivos de criação colaborativa, apontando novas cartografias para a criação e para a arte pública relacional contemporânea. Resulta em ações em rede e colaborações, a partir da articulação entre artistas e profissionais de variados campos do conhecimento, desenvolvendo laboratórios interdisciplinares que precedem ações artísticas efêmeras simultâneas nas cidades participantes, no marco do projeto anual 24 horas: una linea en la ciudad. Tem gerado um corpo bastante consistente de metodologias, documentos, publicações e intercâmbios internacionais entre coletivos artísticos, socioculturais e instituições na América Latina e Europa. 


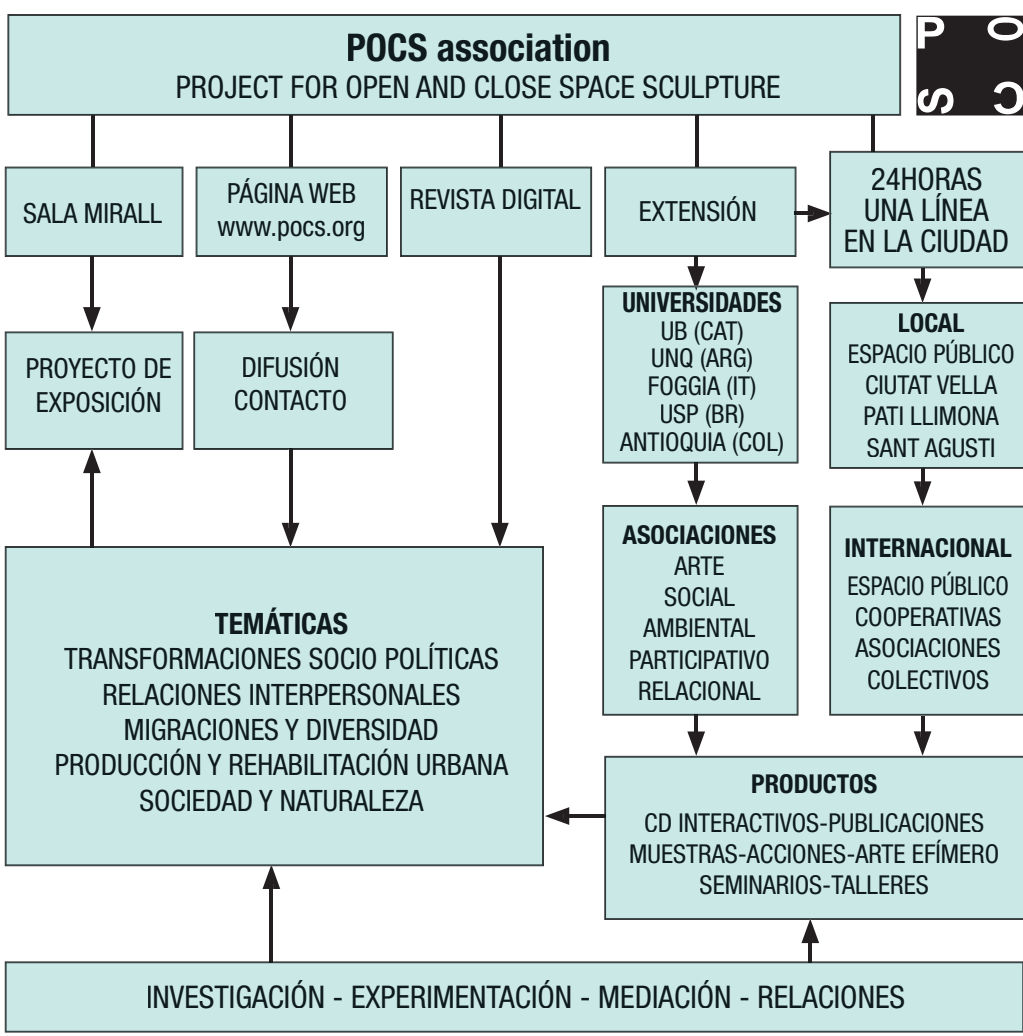

Figura 36 - Diagrama figurativo de POCS Association

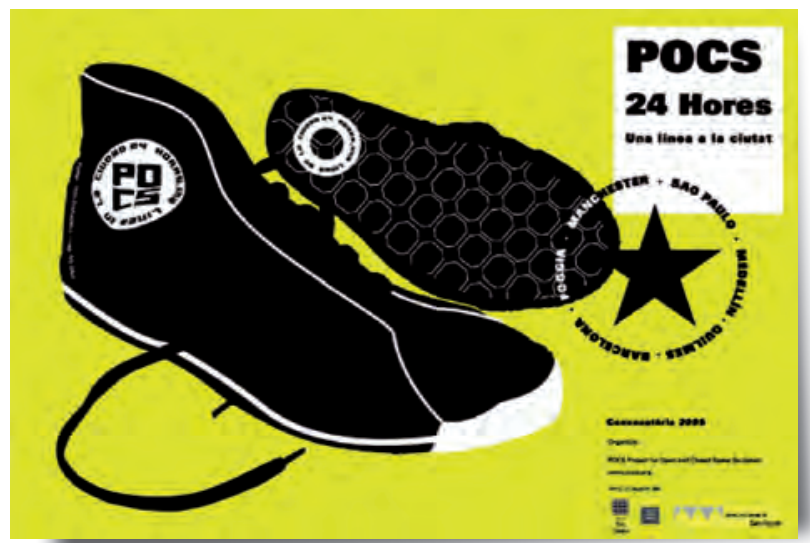

Figura 37 - Postal convite
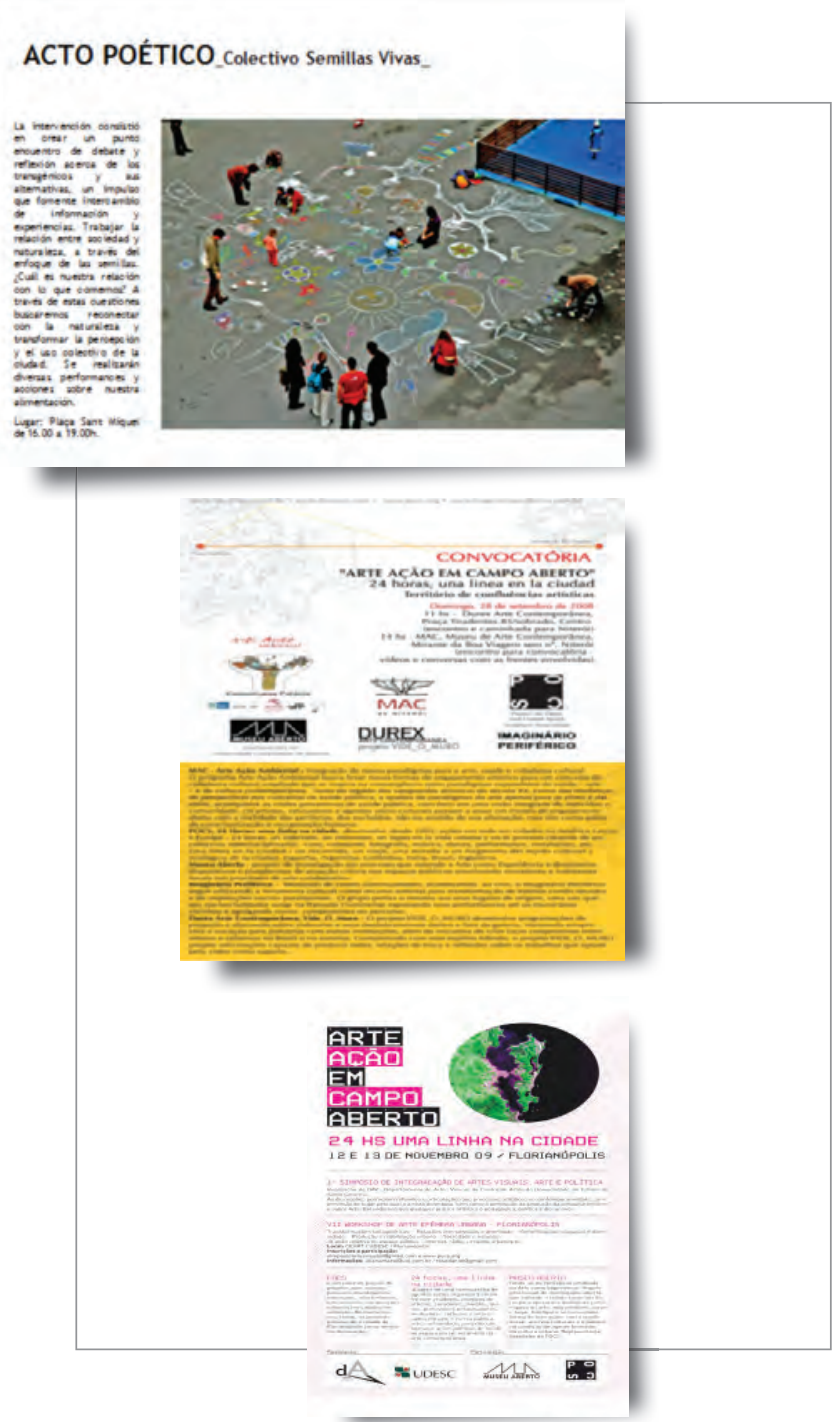

Figuras 38, 39 e 40 - Propostas realizadas no marco do projeto 24 Horas: uma linha na cidade. Colaborações entre POCS, Museu Aberto e parceiros: MAC Niterói, Galeria Durex e Imaginário Periférico, RJ, 2008 e Departamento de Artes Visuais - DAV da UDESC, Florianópolis, 2009 


\subsubsection{Museu Aberto ${ }^{34}$ : a cidade como museu e o museu como prática artística - Paranapiacaba - Museu a Céu Aberto}

A proposta de um museu a céu aberto em Paranapiacaba foi formulada norteando-se pelo projeto de sinalização turistica de rua do referido sítio histórico, instalado em 2004, a partir de estudos e observações dos principais eixos de circulação, seus cruzamentos e dos principais pontos de interesse histórico.

Proposta inovadora de criação de um espaço expositivo e interativo a céu aberto, tendo como plataforma a paisagem cultural da Vila de Paranapiacaba.

Com o intuito de criar espaços integrados à realidade local com intensa interdisciplinaridade e sendo geridos com grande participação social local foi concebida a proposta do museu a céu aberto da vila de Paranapiacaba, incrementando ao museu de rua já existente, um circuito composto por cinco equipamentos públicos que abordam temas vinculados ao patrimônio histórico, natural, arquitetônico/urbanístico, sociocultural e humano, respectivamente: Museu Castelo, Centro de Visitantes do Parque, Centro de Referência em Arquitetura e Urbanismo, Clube União Lyra Serrano e, concluindo o circuito, a Casa da Memória.

0 projeto processual colaborativo Casa da Memória ${ }^{35}$, realizado nos anos de 2007 e 2008 na vila ferroviária de Paranapiacaba, instalada em meio à Serra do Mar, próxima à cidade de São Paulo, tem curadoria e coordenação geral desta autora, artista visual, curadora independente e investigadora no campo da arte e esfera social da Universidade de São Paulo, que opera como artista e pesquisadora no contexto da referida vila desde os anos 2000 .
35 Casa da Memória: Núcleo da Memória Audiovisual da Paisagem Humana de Paranapiacaba. Prefeitura Municipal de Santo André, IPHAN/Minc, UNESCO, 2007-2008. 


\section{Casa da Memória - museu de experiências pessoais no contexto coletivo}

Proposta de investigar as memórias individuais e coletivas dos moradores da Vila de Paranapiacaba, articulando-as numa perspectiva documental audiovisual sistemática com bases tecnológicas.

Define-se como Núcleo da Memória Audiovisual da Paisagem Humana em sua interface direta com o território, como espaço experimental, intermidiático e interdisciplinar contemporâneo, expositivo, educativo e local de encontro para mostras, cursos, palestras, oficinas, apresentações, audições, projeções, assim como de um Centro de Documentação e Referência da Paisagem Humana da Vila de Paranapiacaba. Para tanto, mantém o Laboratório da memória, espaço para registro sistemático de depoimentos dos moradores e visitantes da Vila.

Configura-se no âmbito da experimentação de práticas artísticas contemporâneas que investigam os imaginários urbanos a partir das fronteiras e potências entre linguagens, meios e contextos, com base em processos colaborativos com perspectivas de apropriação, pertencimento e ressignificação do patrimônio material e imaterial urbano. Envolve a comunidade de moradores no processo de desenvolvimento do processo curatorial compartilhado, tendo os Monitores Ambientais e Culturais de Paranapiacaba como Agentes da Memória e Mediadores por excelência, estabelecendo articulações entre arte e vida cultural da comunidade, esfera privada e esfera pública, imaginários urbanos e suas representações, o local e o global.

Num momento em que o fluxo, deslocamento, transitoriedade e velocidade caracterizam a dinâmica de trocas - informações, conhecimento, comunicação contemporânea, e em um contexto em que o Brasil se vê pressionado a repensar sua infraestrutura no âmbito dos transportes, tendo como agravante os desdobramentos resultantes do colapso aéreo especialmente vivido na cidade 


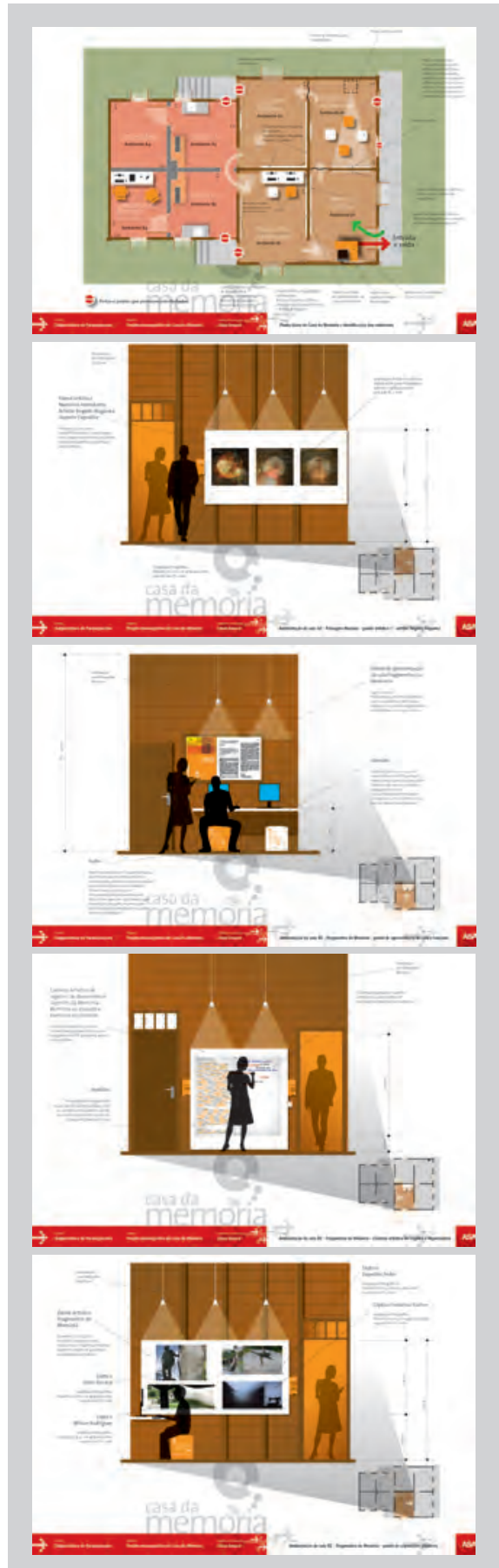

de São Paulo, parece-nos extremamente oportuno colocar em pauta discussões que apontem perspectivas de revitalização do transporte ferroviário que há tanto tempo tem sido relegado à obsolescência e ao esquecimento, apontando possibilidades de reinvenção real e simbólica de preservação do patrimônio, promovendo a mobilização crítica e a transformação social por meio de diálogos mediados pela arte e criatividade.

\section{Casa da Memória - Núcleo da Memória Audiovisual da Paisagem Humana de Paranapiacaba}

Iniciada em 2006 a convite da Subprefeitura de Paranapiacaba/ Prefeitura Municipal de Santo André, a concepção da Casa da Memória - Núcleo da Memória Audiovisual da Paisagem Humana de Paranapiacaba integrou o projeto de Museu a Céu Aberto, concebido como proposta de revitalização da Vila ferroviária junto ao IPHAN Instituto de Patrimônio Histórico e Artístico Nacional/Ministério da Cultura, com o objetivo de criar experiênciaseespaços de memória coletiva e documentação audiovisual referente ao imaginário dos moradores do referido sitio histórico. Desde o ano 2000 vimos desenvolvendo ações dirigidas a implantar dispositivos documentais com base em estratégias da Arte Pública e atuais hibridizações contemporâneas, tendo criado documentários e intervenções, cujos conteúdos se referem às variadas formas de vida e apropriação cultural do território.

\section{Resultados}

A Casa da Memória atuou na Formação de Agentes da Memória entre 2007 e 2008 como proposta de pesquisa, capacitação profissional interdisciplinar e sustentabilidade tecnológica de Rede de Interlocuciones - Blog e página web (em processo). Investigação em processo contínuo e participativo da Memória Audiovisual de Paranapiacaba. 
Criação Coletiva do Arquivo para a Casa da Memória (processo aberto). Centro de Documentação e Referência processual.

Núcleo de Projetos, Recursos e Desenvolvimento Cultural. Núcleo de Documentários, Vídeos e Imagens Fotográficas.

Comissão de Gestão Cidadã: Agentes da Memória, Agentes Culturais, Monitores Ambientais e Turísticos e Gestores Públicos Locais.

Projeto autossustentável com base no Turismo Cultural e Ambiental. Participação Acadêmico-Científica da Universidade de São Paulo e Universidade Anhembi-Morumbi .

Campo de Investigação e Estágio Interdisciplinar.

Concepção e aprovação do projeto de Museu a Céu Aberto. IPHAN /MINC 2007. Rearticulação da Linha Férrea.

Indicação de Paranapiacaba como Patrimônio da Humanidade UNESCO 2008.

\section{OBSERVATÓRIO NÔMADE ${ }^{36}$}

Trata-se de um laboratório multidisciplinar de pesquisa do território baseado em Roma, na Itália, que deposita células de pesquisa em diferentes cidades do mundo. Integra o projeto Stalker/Osservatorio Nomade idealizado por Francesco Careri ${ }^{37}$, que opera no campo da arquitetura e cultura urbana. Atua a partir de métodos como o caminhar como prática estética, entendendo a corporalidade urbana como instância que desfaz a ideia do corpo como categoria genérica e impõe a necessária apreensão das especificidades locais.

A configuração das cidades seria outra caso usássemos nosso corpo-andante de outro jeito. Flanar, vagar, derivar, errar. Motores para pensarmos além da arquitetura sedimentada, desviandonos para perseguir a possibilidade de uma cidade performativa. Walkscapes, a publicação de Careri que aborda o caminhar como

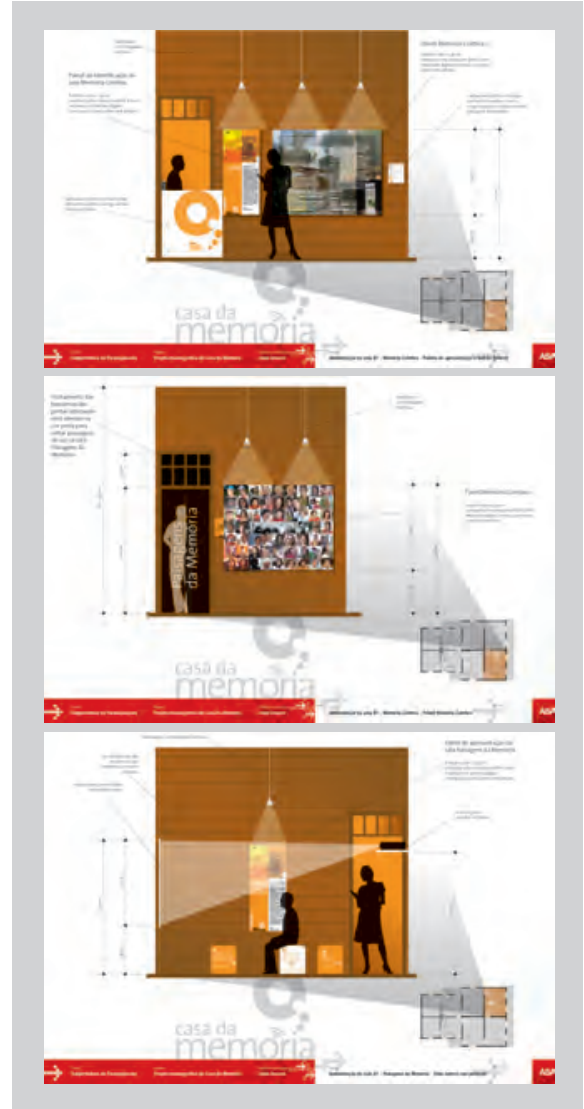

Figuras 41 a 48 - Projeto Museográfico do espaço expositivo da Casa da Memória: Núcleo da Memória Audiovisual da Paisagem Humana de Paranapiacaba

36 http://www.stakerlab.org

37 CARERI F. Walkscapes. El andar como práctica estética. Barcelona: Editora Gustavo Gilli, 2002. Francesco Careri (1966), é professor da Faculdade de Arquitetura da Universidade de Roma e membrofundador do laboratório Stalker/Osservatorio Nomade (www.stalkerlab. org), publicou também Constant. New Babylon, una città nomade (Texto e Inmagine), 2001. Observatório Nômade, sob coordenação de Marti Perran, integra a atual edição de 2009/2010 do projeto IDENSITAT Barcelona/Calaf/Manresa/Mataró/Del Prat de Llobregat. 
prática estética vem difundindo-se em meio aos estudos urbanos brasileiros, especialmente onde existam linhas de pesquisa focadas nas relações entre artes e arquitetura. Trata do deambular como arquitetura da paisagem, do caminhar como forma de arte autônoma, ato primário de transformação simbólica do território, instrumento estético de conhecimento e modificação física do espaço "atravessado" que se converte em "intervenção urbana".

Do nomadismo primitivo ao Dadaísmo e Surrealismo, da Internacional Letrista à Internacional Situacionista e do Minimalismo à Land Art, os métodos e processos desenvolvidos abordam a percepção da paisagem através de uma história da cidade percorrida. Por subsidiar modos de experimentar artisticamente as cidades, engajando corporalidade e devir, as ideias propostas por Careri vem ganhando espaço e inspirando coreógrafos, performers e artistas que trabalham com arte urbana.

\section{IDENSITAT ${ }^{38}$}

Posiciona-se como um espaço de produção e pesquisa em processo, fundamentalmente no campo da arte, para experimentar novas formas de envolvimento e interação no espaço social. Com base em Barcelona, atua nos municípios em seu entorno como uma plataforma de reconhecido prestígio que promove intervenções artísticas no espaço público desde 1999. Idensitat Calaf/Manresa desenvolve propostas e experiências que consistem na realização de uma série de projetos de investigação artística e interação social em núcleos urbanos, tendendo à expansão rumo a outras cidades do entorno, dirigidos à crítica, à pedagogia, a projetos sociais e à criação de redes de debate e participação. Dirigido e com curadoria de Ramón Parramon desde o ano de 1999, artista visual, investigador e coordenador do Máster de Diseño y Espacio Público de ELISAVA - Escola Superior de Diseny / Universidad Pompeu Fabra, Barcelona, Espanha. 
Para Ramón Parramon a palavra "experiência" associada à arte e ao território supõe colocar em evidência que o tipo de atividade artística que se formula no contexto do projeto IDENSITAT pouco tem a ver com a construção de objetos, peças unidimensionais e sim, bastante mais, com o fato de gerar situações concretas, processos abertos, análises de caráter crítico, intervenções pontuais no espaço ou outras possibilidades que se desenvolvem a partir da especificidade da proposta e da interação com o lugar. Esta atitude, segundo Parramon

(...) consiste em ativar coisas através de uma certa dinâmica de complexidade que tem a ver com o conceito de ecologia cultural introduzido por Reinaldo Laddaga para explicar certos tipos de trabalhos artísticos de natureza formal desconexa, que compartilham do interesse por convergir no espaço social e conectar-se com comunidades concretas. Gerar "ecologias culturais" ou experimentar na sua criação é uma aproximação para falar do tipo de atividades que se formulam em torno de IDENSITAT (PARRAMON, 2007: 11).

IDENSITAT desenvolve processos que não podem se realizar sob um único formato, que introduzem noções de proximidade em relação às pessoas que podem participar e integrar certos projetos, tipos de propostas nas quais diminui a observação silenciosa e a distância entre produtor e receptor se reduz.

Quando a distância entre ambos agentes participantes do ato comunicativo diminui, a noção de autoria reclama uma interpretação diferente da habitual. Se uma proposta se formaliza a partir da interação, da participação ativa e criativa de diferentes pessoas, o conceito de autor se questiona (LADDAGA, 2006:135).

Segundo Parramon, IDENSITAT tem fomentado propostas e desenvolvido uma linha de atuação cada vez mais implicada

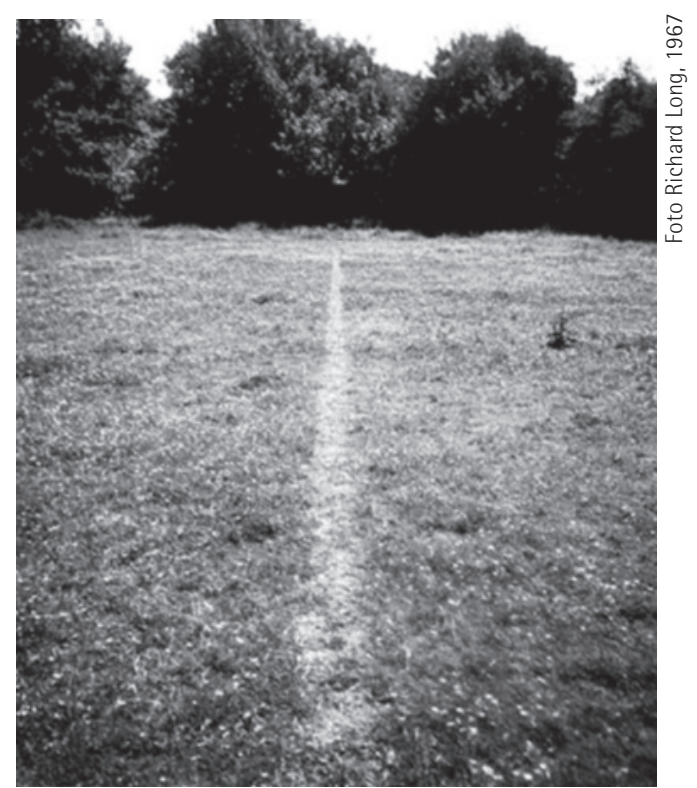

Figura 49 - A line made by walking. 
com processos de transformação social no território onde atua, envolvendo as práticas artísticas no campo da cultura local. Observa que:

La intervención crítica, los procesos de interacción social y la hibridación entre diferentes disciplinas, son objetivos trabajados desde los inicios de este programa. Constituyen, en la actualidad, aspectos investigados en un elevado número de propuestas artísticas que persiguen establecer una relación con territorios concretos, articular un trabajo en red con personas y colectivos, así como participar de manera activa en la transformación de determinados elementos de la realidad social loca ${ }^{\beta 3}$.

Nesta perspectiva, pode-se concluir que IDENSITAT tem configurado uma cartografia de ações contínuas e interrelacionadas, a partir do agenciamento de práticas culturais que incidem no desenvolvimento local, ampliam o diálogo e a participação de coletivos e comunidades, poderes públicos e campos de criação em rede.

Vivemos hoje em um mundo de conflitos diversos, onde paradigmas de sociabilidade são o tempo inteiro questionados, e por ter sido tão extenso, nas duas últimas décadas, o movimento de aproximação da política à estética, se faz necessário destacar a singularidade da arte em relação ao campo da cultura, afirmando a primeira como meio de apreensão do mundo e de reinvenção da realidade. Não se pretende reduzir a criação artística ao mero comentário ou à ilustração do que se passa no campo ampliado

39 Texto comentado durante a realização da apresentação do Projeto Idensitat por Ramon Parramon, no âmbito das Jornadas Abiertas Interculturales Miradas al Arte Público Contemporáneo: Geografias de la Inclusión y Transformación Social, Universidade Complutense de Madrid, outubro de 2008, no curso de PósGraduação, Linha de pesquisa Arte, memória e identidade, dirigido pela Profa. Dra. Marián Cao. da vida, mas justamente afirmar, como se pretende propor no debate circunscrito a esta investigação acadêmica e cultural em processo, que a arte é uma maneira de entender o mundo que não se reduz a outra qualquer e a potência da arte como território existencial. 


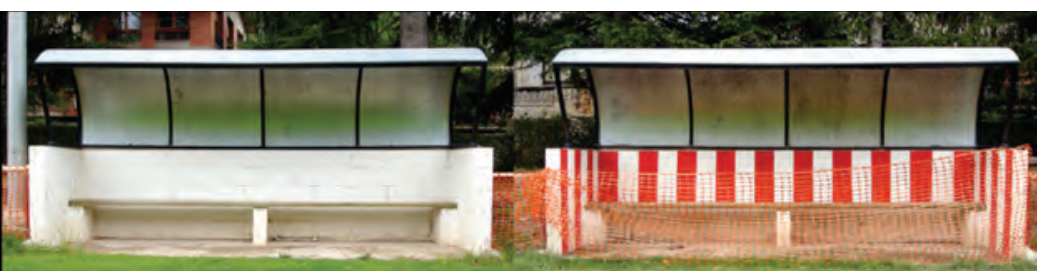

\title{
IDENSITAT07
}

\author{
Calaf + Manresa + Mataró + Priorat
}

un laboratorio de desarrollo de proyectos, ofreciendo la

oportunidad de intervenir de una manera activa en procesos urbanos-rurales en el momento en que se produce un

importante fenómeno de expansión y crecimiento, así como de redefinición de la identidad, imagen o marca, a través de las cuales quieren proyectarse.

Figuras 50 e 51 - Idensitat 2007. Tema: Local / Visitante 


\section{MADRID ABIERTO ${ }^{40}$}

Coordenado e dirigido pelo curador independente, filósofo e gestor cultural Jorge Díez, Madrid Abierto configura-se como uma plataforma estável de projetos de arte pública na cidade de Madri. Projeto estabelecido a partir de convocatórias abertas à participação de artistas de todo o mundo, ocorre concomitantemente à realização da ARCO, Feira Internacional de Arte Contemporânea.

Aponta para uma linha de atuação cultural e curatorial mais focada na ideia da cidade como suporte para a prática artística, assemelhando-se, de certa forma, ao modelo e procedimentos adotados pelo projeto brasileiro Arte/Cidade, que de uma maneira, ainda que aberta a novas experimentações, aproxima-se da ideia da cidade espetáculo, baseado na criação de obras objetos mais do que em experiências/processos, sendo por isso, revista e repensada continuamente pelo grupo de profissionais que atuam na gestão crítica do projeto, entendendo a necessidade de ampliar seus canais de comunicação, inserção e participação cidadã.

Estimula práticas emergentes que se engendram de modo fundamental com o entorno urbano da cidade de Madri, apontando exemplos de uma ampla variedade de formas artísticas que estabelecem sua respectiva solidez, desempenhando papéis ampliados que aspiram a obter resultados no terreno social do exercício da arte e da participação do público.

Promove a criação e exposição de obras que estabelecem relação com diversas disciplinas e que sejam abertas a colaborações entre artistas, arquitetos, designers, programadores informáticos, cientistas sociais, planejadores urbanos e outros. Centra-se em espaços que tem sido dados como "públicos", mas que dão sinais de privatização cada vez maior. Madrid Abierto, segundo Jorge Diez: 


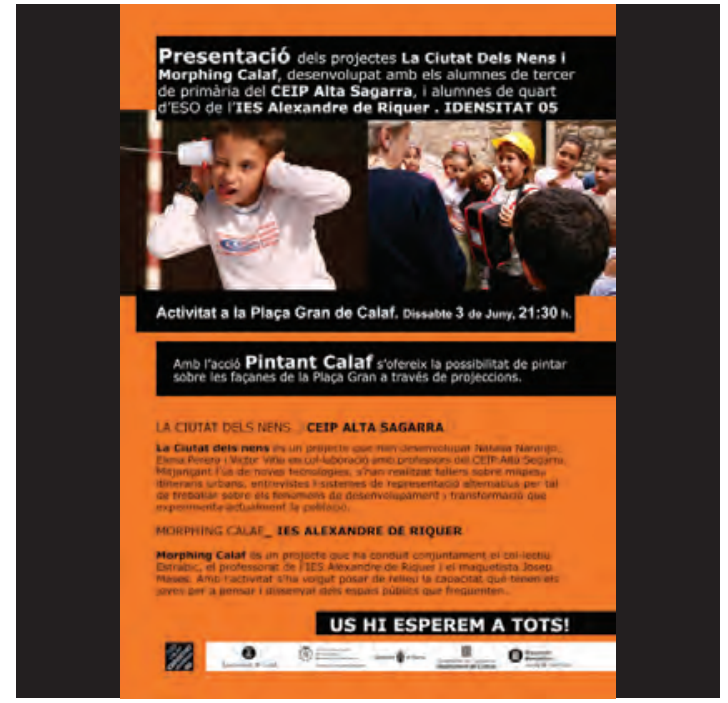

Figura 52 - Apresentação dos projetos La Ciutat Dels Nens e Morphing Calaf, com alunos do CEIP Alta Segarra e alunos do IES Alexandre de Riquer. Idensitat, 2005

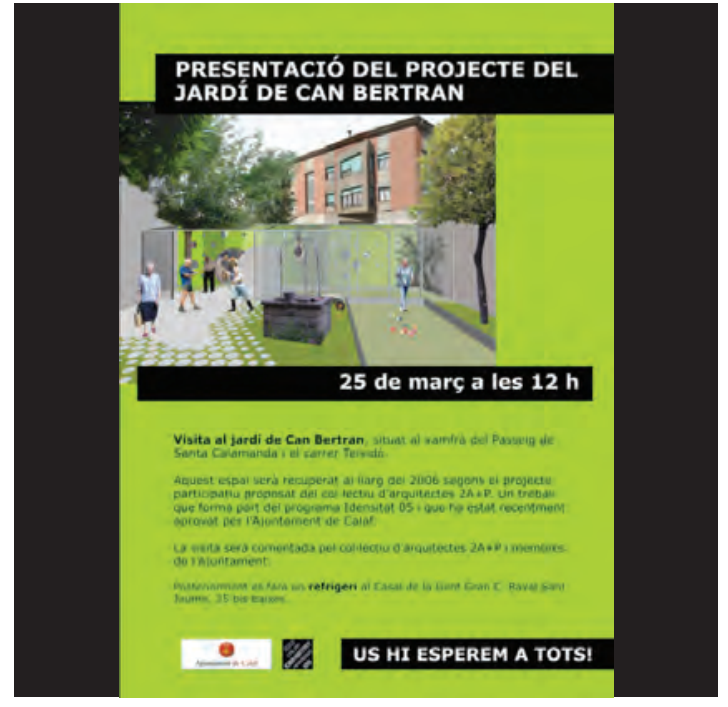

Figura 53 - Apresentação de Projeto de Jardim Público especialmente elaborado e executado coletivamente para criar espaços de sociabilidade intergeracional com ênfase nas necessidades e desejos dos moradores mais idosos

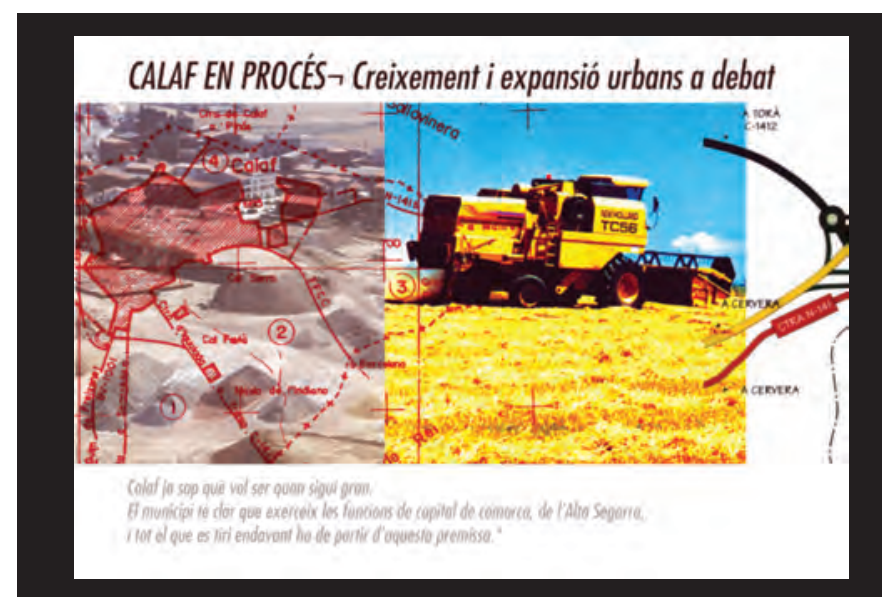

Figura 54 - Proposta de discussão pública acerca dos processos de crescimento e expansão da cidade de Calaf no contexto do Projeto IDENSITAT, 2007

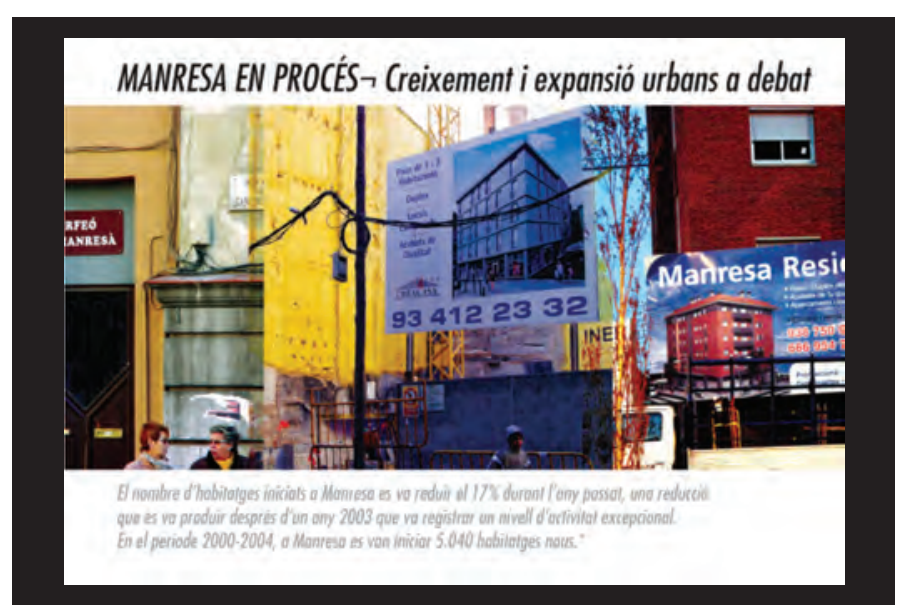

Figura 55 - Proposta de discussão pública acerca dos processos de crescimento e expansão da cidade de Manresa no contexto do Projeto IDENSITAT, 2007 
interdisciplinares ou a forma como podem a inércia e a nostalgia serem substituídas por ferramentas visionarias e inspiradoras que atuem como catalisadores da transformaçã $0^{41}$.

Vale destacar, neste sentido, a contribuição das Jornadas Abiertas Interculturales Miradas al Arte Público Contemporáneo: Geografías de la Inclusión y Transformación Social, realizadas na Universidade Complutense de Madrid como iniciativa acadêmica e cultural proposta por esta investigadora, tendo estabelecido uma aproximação importante entre os questionamentos da Associação Cultural Madrid Abierto acerca das formas de produção, difusão, inserção e consumo da arte em meio à vida urbana e as proposições de mediação cultural com as quais o Museu Aberto e a Casa da Memória operam.

Iniciou-se, em decorrência de tais diálogos, um processo de parceria interinstitucional proficua entre a Prefeitura, a qual o projeto Madrid Abierto está vinculado e a Universidade Complutense de Madrid, que na ocasião, buscava espaços de pesquisa e experimentação no campo da mediação artística e educativa com base nas relações entre arte e esfera pública que a arte urbana propicia, ampliando os canais de estágio e investigação junto aos alunos do Programa de Pós-Graduação, no qual atuamos como docente e pesquisadora. Assim, Universidade, Instituição Cultural, Prefeitura da Cidade de Madri e sociedade ampliaram suas conexões locais, formulando propostas relacionais de largo alcance que passaram a contemplar as demandas sociais, destacando o espaço da cidade, o habitante e a experiência urbana como o centro e a justificativa mesma para tais operações de política pública no campo ampliado da cultura urbana.

41 Texto comentado por Jorge Diez no contexto das Jornadas Abiertas Interculturales Miradas al Arte Público Contemporáneo: Geografias de la Inclusión y Transformación Social, Universidade Complutense de Madrid, outubro de 2008, no curso de PósGraduação, Linha de pesquisa Arte, memória e identidade, dirigido pela Profa. Dra. Marián Cao. 


\subsection{JORNADAS ABERTAS INTERCULTURAIS - WORKSHOPS INTERNACIONAIS DE ARTE PÚBLICA CONTEMPORÂNEA}

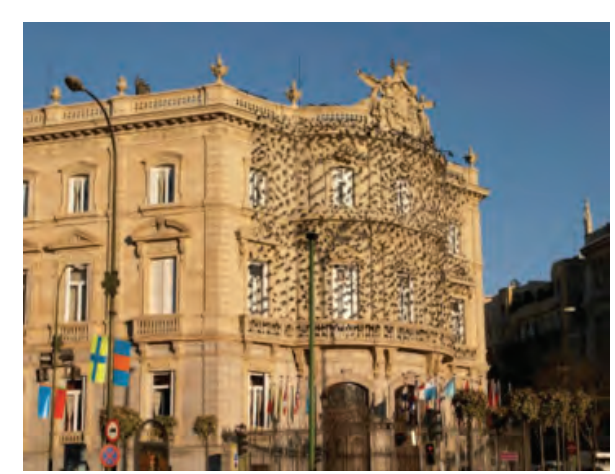

Figura 56 - Diana Larrea: Palacio encantado, Madrid Abierto 2008.

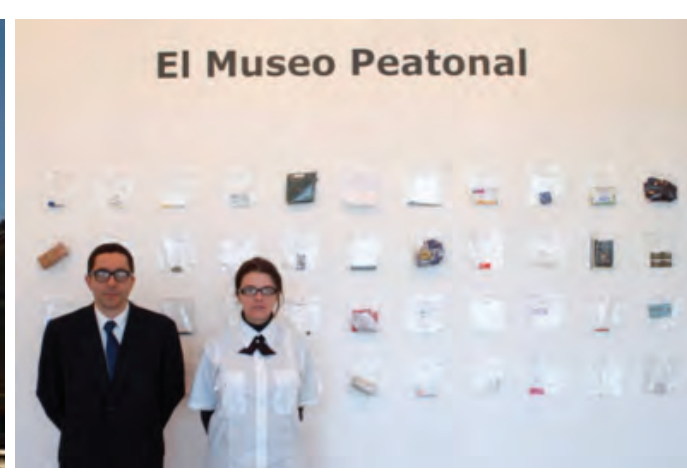

Figura 57 - María Alós y Nicolás Dumit Estévez: El Museo peatonal, Madrid Abierto, 2008

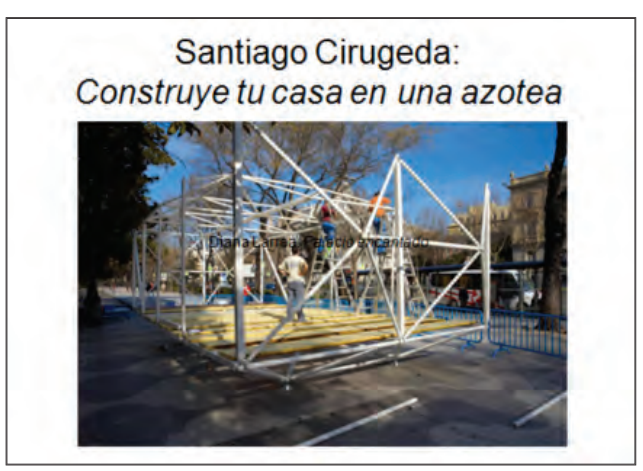

Figura 58 - Madrid Abierto, 2008.

A realização de três workshops - Interterritorialidades: fronteiras da arte pública contemporânea, Interterritorialidades: corporeidade e cidade, coordenadas por Daniel Toso (POCS) e por esta autora (Museu Aberto); Arte e inclusão através da imagem, ministrada por Ana Mampaso (UAM) e o Taller teórico-experiencial interpretativo de fotografia do espaço público, coordenado pelo Prof. Dr. Francisco García García (UCM) com nossa co-autoria (USP), estabeleceram diálogo com os projetos apresentados no marco da abertura das Jornadas Abiertas Miradas al Arte Público Contemporáneo, colocando em ação questões teórico-práticas apontadas na mesa redonda da qual participaram Ramon Parramon, Idensitat, Jorge Díez, Madrid Abierto, Marián Cao, diretora do PósGraduação na linha de pesquisa Aplicações da Arte na Integração social, a partir da disciplina "Arte, Memória e Identidade", na qual atuamos como docente e pesquisadora.

Os workshops ativaram e criaram espaços de experimentação na cidade, tomando-a como campo de investigação estética. A 
Arte Pública, suas atuais derivações e implicações no espaço social contemporâneo estabeleceram os eixos para as criações colaborativas efêmeras, intervenções fotográficas, videográficas e performáticas. Experiências estéticas ocuparam espaços transitórios na cidade de Madri, reinventando formas de habitar a cidade contemporânea por artistas audiovisuais, arte-terapeutas, docentes e investigadores da Espanha, Chile, Portugal, Brasil, Colômbia e Argentina.
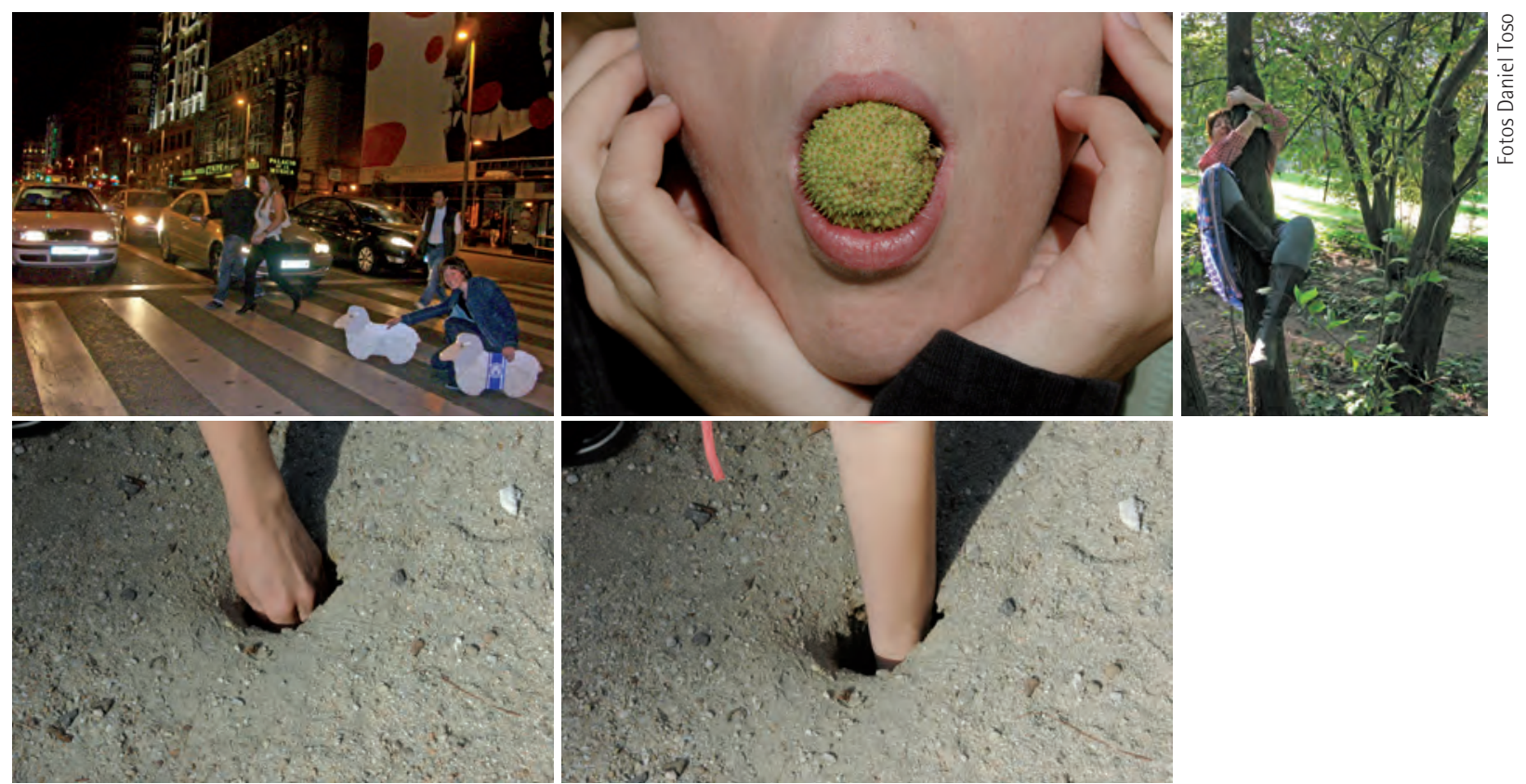

Figura 59 - Imagens Workshops Madri

No Brasil foram projetadas e realizadas ações no mês de setembro de 2008, antecedendo as discussões e propostas desenvolvidas na cidade de Madri, configurando as Jornadas Abertas "Arte e Ação em Campo Aberto". Operou-se com a ideia de criação de uma linha virtual de articulação e visibilidade entre espaços culturais localizados no centro (degradado) da cidade do Rio de Janeiro e de Niterói, ambos lugares entendidos como "periferia cultural" da cena contemporânea carioca. 
Embora estejam no centro geográfico, ocupam uma posição periférica e reivindicam o reconhecimento de suas inserções no campo da cultura urbana. POCS - Project for Open and Closed Space Sculpture Association, coletivo artístico com base em Barcelona e o Museu Aberto, em colaboração com os artistas gestores da Galeria Durex, localizada no centro histórico da cidade do Rio de Janeiro, no entorno da Praça Tiradentes, em diálogo com o Museu de Arte Contemporânea de Niterói e o coletivo Imaginário Periférico, acolheram a proposta de encontro entre artistas audiovisuais, arte-educadores, curadores, pesquisadores e gestores culturais. Foi promovido um deslocamento do grupo de participantes da galeria até o MAC Niterói, a partir de uma caminhada - como prática estética, que utilizou o percurso a pé e de balsa para experimentar e apontar os enfrentamentos e as confluências da convivência e da alteridade na cidade. A ação de deslocamento conceitual e prática coletiva criou uma linha virtual e simbólica entre as cidades do Rio de Janeiro e Niterói, conectando e ativando as "periferias e o centro".

No auditório do MAC Niterói realizou-se uma discussão aberta acerca das práticas colaborativas descentralizadas, autogestão e sistema das artes, documentação como obra processual da qual participaram os artistas da galeria Durex, do POCS (Espanha) e Museu Aberto (Brasil) e o coletivo Imaginário Periférico, integrado por mais de 300 artistas que vivem e atuam na periferia do Rio de Janeiro, além da equipe de educadores do museu e jovens da comunidade do Morro do Palácio envolvidos no projeto Arte e Ação Ambiental, uma colaboração internacional entre o MAC Niterói e o Andy Warhol Museum, que resultou na criação do anexo do MAC Niterói, implantado no Morro do Palácio, que teve início em 1998.

As Jornadas Abertas fixaram sua atenção na crítica às narrativas midiáticas oficiais sobre as políticas de construção da memória atuais, tanto no estado espanhol como brasileiro. Os 


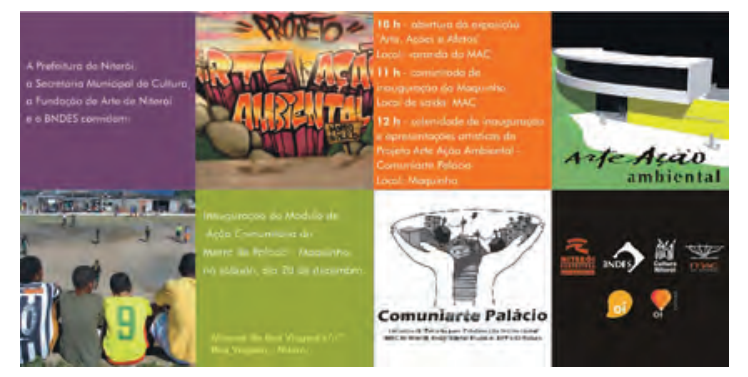

Figura 60 - Convite para a inauguração do MAC Anexo, local para desenvolvimento de ações e agenciamentos socioculturais, com base no projeto Arte Ação Ambiental, dezembro, 2008 conteúdos e resultados apresentados estabeleceram importante marco discursivo e de intercâmbio científico-cultural, colocando em relevo o papel social do artista e das instituições culturais e acadêmicas nos processos de transformação social em contexto ibero-americano.

Com base no mapeamento, descrição e análise de experiências atuais, propomos iniciar a criação coletiva de uma cartografia, ou melhor dizendo, de uma geoecologia desta nova cultura vinculada a processos mais vastos de modificação das formas de ativismo político, produção econômica e investigação científica que definem, em sua novidade, o presente. 


\section{CONSIDERAÇÕES FINAIS EM PROCESSO: TECENDO REDES DE AFETOS E PERCEPTOS}

0 que fica dos lugares e objetos que conhecemos são vestígios, marcas, sinais e seu desaparecimento cria lacunas em nosso repertório, imagens que oscilam entre uma vaga lembrança e o absoluto esquecimento.

Não se trata de congelar, preservar indistintamente sem considerar o espaço para mudança, o novo, a renovação. Tratase de considerar a necessidade de se reconstruir, também, certas paisagens interiores destruídas ao reapropriar-se de bens de alcance social.

Extrapolando as instituições como o museu ou a escola, é possivel encontrar nos espaços vividos nas cidades uma fresta por onde penetra a subjetividade, muito além da perspectiva oficial. Assim, criam-se lugares, heterogeneidades num território tornado abstrato, sem diferenciação. E tais lugares, tornam-se, assim, fontes de inter-relação, suporte de comunicação e organização de sentido.

Os percursos sobre os quais nos detivemos caracterizam-se por ativar espaços e resultam em escrituras coletivas, possivelmente incompletas, mas que pretendem dar margem a discussões profundas a respeito do futuro das cidades e, sobretudo, do lugar que os homens devem nelas ocupar.

Com base nos projetos realizados por artistas, curadores, críticos, educadores, gestores e agentes socioculturais nos diversos contextos articulados, bem como nas interfaces estabelecidas em tais lugares (reais e simbólicas), delineamos rotas para possíveis leituras, interpretações e apropriações do sentido alargado desta "Rede de Afetos", urdida numa perspectiva interdisciplinar que tem contribuído para diluir fronteiras e operar nos interstícios do pensamento-ação e da prática artístico-crítica contemporânea. 
Criam, assim, dispositivos de interlocução, mediação sociocultural e difusão da arte em rede no contexto da vida cotidiana, tecendo arquiteturas de relações, do local ao global. Delas resultam certa "geografia do atrito", entendida menos no sentido do confronto, mas, ao contrário, no da fricção, provocando encontros e novos sentidos para tais percursos e deslocamentos existenciais e poéticos. No interior de um amplo espectro de trabalhos realizados em contextos, meios e linguagens tão variadas quanto a procedência e as poéticas de seus autores, encontramos blocos de sentidos e práticas interculturais convergentes, a partir das quais, por afinidades, definimos conjuntos que articulam arte colaborativa, memória e identidade.

Configurados no âmbito da experimentação de práticas artísticas contemporâneas que investigam os imaginários urbanos a partir das fronteiras e potências entre linguagens, meios e contextos, diversos trabalhos apresentados no entorno do Museu Aberto - Casa da Memória: Núcleo da Memória Audiovisual da paisagem Humana de Paranapiacaba, assim como nas Jornadas Abiertas Interculturales: Miradas al Arte Público Contemporáneo: Geografias de la Inclusión y Transformación Social, na Universidade Complutense de Madrid e no Rio de Janeiro/Niterói, quanto no entorno do Seminário Internacional Acciones Reversibles, em Vic, Espanha, partem de processos colaborativos como base para perspectivas de ressignificação do patrimônio material e imaterial urbano, encontrando na arte pública expandida e na estética relacional sua plataforma de operações.

Tais processos fundam-se na concepção expandida da Arte como Experiência, tendo o território como contexto para criações coletivas que envolvem artistas e não-artistas, estimulando a pesquisa, criação, documentação, difusão e apropriação crítica e criativa.

Investidos de uma nova atitude pautada numa maior proximidade entre arte e política, identificamos, por meio de inter[in]venções, percursos e composições urbanas, "a concepção 
da arte calcada no enraizamento das práticas sociais coletivas, indicando uma relação produtiva entre arte e gestão do espaço público (...) resultando em invenções criativas para formas do habitar" (VELOSO, 2004-5: 113).

Apresentam uma visão dialógica de espaço da arte, vida cotidiana, corpo e lugar, acreditando firmemente que é possivel construir e reconstruir outros tipos de cidades, reais e imaginárias. $\mathrm{Na}$ (re)invenção da cidade, o urbanismo cidadão é exercido pelos habitantes e potencializa os imaginários urbanos (SILVA, 2001). Estudar os urbanismos cidadãos é não somente examinar práticas cidadãs na construção de identidades sociais e de ações contra os poderes, mas uma intenção de compreender esses novos modos de apresentação cidadã, que consolidam ou desafiam os modos estabelecidos de viver o presente e de imaginar o futuro.

No que tange ao direito à cidade, podemos entender que a gestão participativa está no centro de todas as questões que afetam seu desenvolvimento democrático, criando o mapa simbólico da cidade para visualizar narrativas em conflito, capturando a imagem e identidade do lugar.

Críticas contrárias ao marketing urbano, tais como exercícios simplistas e elitistas, emergem em paralelo a uma demanda para incrementar o orgulho local e a crença de que utilizando atividades culturais como elemento catalisador para a recuperação da cidade pode-se ajudar a criar uma ponte entre as necessidades de imagem externa e identidade local.

Neste sentido, a produção e representação de uma história como também de uma imagem consensual sobre o processo de revitalização urbana podem ser consideradas como uma manifestação chave da gestão democrática da cidade, criando linhas de atuação que giram em torno das políticas de representação, das práticas de legitimação discursivas e da crítica aos modelos de visualidade curatorial, midiática e urbanística. As mercadorias simbólicas serão lidas a partir de suas relações com 
as práticas artísticas contemporâneas, com o trabalho criativo e com as novas formas de produção de subjetividades através da representação cultural, dando visibilidade a um conjunto de práticas de produção e consumo das identidades locais - capitais simbólicos culturais - em um contexto bem definido como o do espaço público intercultural das cidades contemporâneas.

As representações da cidade, fixas ou fluidas, dimensionam características ao mesmo tempo sociais e semióticas. Enquanto sociais são representações que surgem na cidade e demarcam sua inserção na história do espaço urbano. Enquanto semióticas são informações/ações que se processam pela cidade que Ihes é suporte. Considerando-se que estas informações/ações são fluidas e velozes, correspondem aos fluxos que inspiram e patrocinam ações na simultaneidade espaço/temporal que caracteriza os processos eletrônicos da comunicação e são responsáveis pelo diálogo e tensão entre cidades distantes ou próximas no tempo e no espaço ou entre lugares de uma só cidade.

Hábito e experiência representam-se visualmente, porém a natureza da imagem produzida tem ontologias diversas que permitem falar em visualidade - para designar a imagem que se insinua na constatação receptiva do visual físico e concreto das marcas fixas que referenciam a cidade e a identificam e visibilidade - que corresponde à elaboração perceptiva e reflexiva das marcas visuais que ultrapassam o recorte icônico para ser flagrada em indícios.

Do espetáculo à experiência da cidade passa-se às diferenças entre visualidade e visibilidade, passa-se da cidade ao lugar, e de uma semiótica visual da cidade a uma semiótica do lugar invisivel. Opera-se uma distinção entre visualidade e visibilidade, entre recepção e percepção, entre comunicação e informação, entre padrão e dinâmica de valores culturais. Em todas essas diferenças se produzem metamorfoses do olhar.

A visibilidade do lugar como criadora de sentidos e significados da cidade e na cidade nos leva a rever conceitos de espaço próximo 
ou distante, local ou global e, parece, um rejeita o outro e se podem anular como diferença. Em cada lugar processam-se conexões entre lugares próximos ou distantes, vizinhos ou longínquos, em cada lugar confrontam-se diversidades, diferença e identidades.

A percepção do lugar não depende da forma na cidade, mas do olhar do leitor - capaz de superar o hábito e perceber as diferenças: um olhar que se debruça sobre a cidade para perceber suas dimensões, e sentidos que estabelecem o lugar como fronteira entre a cidade e o sujeito atento. Para esboçar uma conclusão, ainda que processual, evocamos as ideias de Lucrecia Ferrara (2003) que aponta ser essa a base epistemológica da visibilidade da cidade pelo lugar, porque se a visualidade da cidade está nas formas que a constroem, a visibilidade está na possibilidade do sujeito debruçar-se sobre a cidade, seu objeto de conhecimento, para, ao produzi-la cognitivamente, produzir-se e perceber-se como leitor, criador e cidadão. 


\section{Referências Bibliográficas}

ANJOS, Moacir dos. Local/global: arte em trânsito. Rio de Janeiro: Jorge Zahar Editor, 2005.

AMARAL, Lilian, BASSANI, Jorge. As Cores do MAC. Museu de Arte Contemporânea da Universidade de São Paulo, São Paulo, 1989/1990.

AMARAL, Lilian. Fronteiras do Visivel: Arte Pública na Avenida Paulista. Um estudo-intervenção na cidade de São Paulo. Dissertação de Mestrado defendida na ECA/USP, 2000.

ARANTES, Otilia. Os Novos Museus. Novos estudos. São Paulo: Cebrap, 1991, p. 3.

ARENDT, H. A condição humana (1951). Tradução de Roberto Raposo. Rio de Janeiro, Forense Universitária, 1991, 4. ed.

BARBOSA, Ana Mae. Lilian Amaral e Corpo Poético. São Paulo : Sesc Pinheiros, 1996.

Tópicos Utópicos. Belo Horizonte: Editora C/Arte, 1998.

BARBOSA, Ana Mae, COUTINHO, Rejane Galvão (Orgs.). Arte/educação como mediação cultural e social. São Paulo : UNESP, 2009.

BASBAUM, Ricardo. Além da pureza visual. Porto Alegre : ZOUK, 2007.

BLANCO, Paloma; Carrillo, Jesús; Claramonte, Jordi; Expósito, Marcelo. Modos de hacer. Arte crítico, esfera pública y acción direta. Ediciones Universidad de Salamanca, 2001. 
BENJAMIN, Walter. Magia e Técnica, Arte e Politica. Obras Escolhidas. São Paulo : Brasiliense, 1985, 1ª. Edição,

BOURRIAUD, Nicolas. Estética relacional. Buenos Aires: Adriana Hidalgo. Editora, 2006.

BOURRIAUD, Nicolas. Pós-produção. Como a arte reprograma o mundo contemporâneo. São Paulo : Martins, 2009.

BOURRIAUD, Nicolas et all. Heterocronias. Tempo, Arte y Arqueologías del Presente. Murcia : CENDEAC, 2008.

BOUSSO, Victoria Daniela. Instalação. Panorama da Arte Atual Brasileira, Formas Tridimensionais. São Paulo: Museu de Arte Moderna de São Paulo,1988/1989.

BURGER, Christa. The Disappearence of Art: The Postmodernism Debate in The U.S Telos. New York : Summer, 1986, p. 93.

CALVINO, Ítalo. Seis Propostas para o Próximo Milênio. São Paulo, Companhia das Letras, 1988.

CANCLINI, Néstor Garcia. Culturas Hibridas: Estratégias para entrar e sair da modernidade. São Paulo : Editora da Universidade de São Paulo, 1997.

Diferentes, desiguales y desconectados. Mapas de la Interculturalidad. Gedisa Editorial: Barcelona, 2004.

Reabrir espacios públicos. Políticas culturales y ciudadania. Plaza y Valdés editores-Universidad Autónoma Metropolitana : México, 2004. 
CHAUI, Marilena. "Janela da Alma, Espelho do Mundo", in NOVAES, Adauto [Org]. O Olhar. São Paulo: Companhia das Letras, 1988.

CRIMP, Douglas. Sobre as Ruínas do Museu. São Paulo: Martins Fontes, 2005.

DELEUZE, Gilles. Conversações. São Paulo: Editora 34, 1992.

DEUTSCHE, Rosalyn. "Public Art and its issues". H. Senie, S. Webster (eds.), in Critical issues in Public Art - content, context, and controversy. Nova York: Harper-Cillins, 1992.

FERRARA, Lucrecia D'Alessio. Lugar na Cidade: Conhecimento e diálogo. In: SOUZA, Maria Adélia de. (org.). Território Brasileiro: Usos e Abusos. Campinas : Editora TERRITORIAL, 2003.

FINKELPEARL, Tom. Dialogues in Public Art. Cambridge: MIT Press, 2001.

FREIRE, Maria Cristina Machado. Além dos Mapas. Tese de doutorado, IPUSP, 1995.

FOSTER, Hal. El Retorno del real. La vanguardia a finales de siglo. Madrid : Ediciones AKAL, 2001.

FREIRE, Cristina. Arte Conceitual. Rio de Janeiro: Jorge Zahar Editor, 2006.

IRWIN, Rita. "A/r/tografia: Uma Mestiçagem Metonímica", in BARBOSA, Ana Mae e AMARAL, Lilian (Orgs.). Interterritorialidade: midias, contextos e educação. São Paulo : Editora Senac/SESC-SP, 2008.

LACY, Susanne. Mapping the terrain. New Genre Public Art. Bay Press, Seatle (NGPA) USA, 1995. 
LADDAGA, Reinaldo. Estética de la Emegencia. Buenos Aires : Adriana Hidalgo Editora, 2006.

MATOS, Olgária C. F. "Imagens Sem Objetos", in NOVAES, Adauto [Org]. Rede Imaginária: televisão e democracia. São Paulo : Companhia das Letras / Secretaria Municipal de Cultura, 1991.

MELLO, Christine. Extremidades do Vídeo. São Paulo : Editora Senac, 2008.

MITCHELL, William JT. Art and the Public Sphere. Chicago University of Chicago Press, 1992.

MUSSET, Alain. Geohistoria o geoficción? Ciudades vulnerables y justicia spacial. Medellin : Editorial Universidad de Antioquia, 2009. 266p. 22cm (Collección sociología). ISBN:978-958-714-235-8.

PARRAMON, Ramon. IDENSITAT: Arte, Experiencias y Territorios en Proceso. Espacio Publico / Espacio Social. Calaf / Manresa : Associació d'Art Contemporani, 2007.

PEIXOTO, Nelson Brissac. Paisagens Urbanas. Editora SENAC São Paulo : Editora Marca D'Água, 1996.

QUEIROGA, E. A megalópole e a praça: 0 espaço entre a razão e a ação comunicativa. São Paulo, 2001. Tese de doutorado. Faculdade de Arquitetura e Urbanismo, Universidade de São Paulo.

RICARTE, Marta. SAURA i SAULA, Eric (Orgs). Procesos Creatius transformadors. Els projectes artístics dintervenció comunitária protagonizats per joves a Catalunya. Barcelona : Ediciones del Serbal, 2009. 
SANTOS, Milton. Técnica, espaço, tempo: Globalização e meio técnico-científico informacional. São Paulo, Hucitec, 1994.

SILVA, Armando. Álbum de Familia: A imagem de nós mesmos. São Paulo : Editora SENAC São Paulo, Edições SESC SP, 2008.

Imaginários Urbanos. São Paulo : Perspectiva ; Bogotá: Convenio Andrés Bello, 2001. Estudos ; 173.

TILLY, Charles. Stories, Identities and Political Change. Nueva York y Oxford: Rowman \& Littlefield, 2002.

VARELLA, Drauzio, BERTAZZO, Ivaldo, JACQUES, Paola Berenstein. Maré, vida na favela. Rio de janeiro : Casa da Palavra, 2002.

\section{Artigos, Catálogos e Revistas}

AMARAL, Lilian. Mapas Urbanos: Arte Contemporânea, a cidade e o público. 23a Bienal Internacional de São Paulo, 1996.

FREIRE, Maria Cristina Machado. Intervenção Artística no Espaço Público. Folder de apresentação. São Paulo : Museu de Arte Contemporânea, 1991.

HONORATO, Caio. A arte como atitude. Entrevista com Luís Camnitzer. In: Concinnitas: arte, cultura e pensamento. Rio de Janeiro : UERJ, DEART, 2008, n. 12.

KWON, Miwon. The wrong place. In: Art Journal. EUA, 2000.

One place after another: notes on the Site Specificity. In: October 80. EUA, 1997.

VELOSO, Mariza. Rede Nacional de Artes Visuais. Rio de Janeiro: FUNARTE / Ministério da Cultura, 2004/2005. 



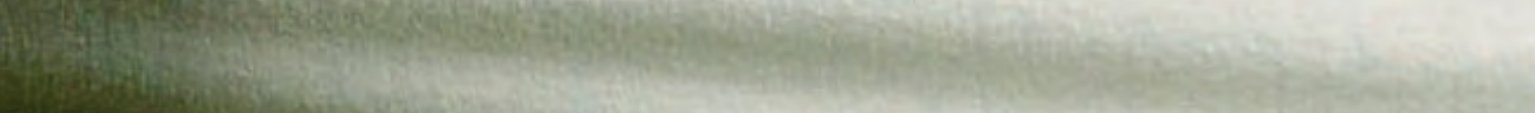

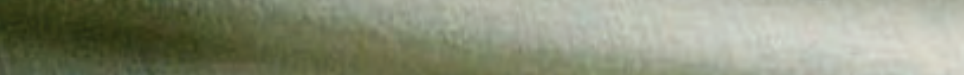

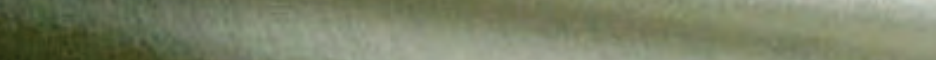

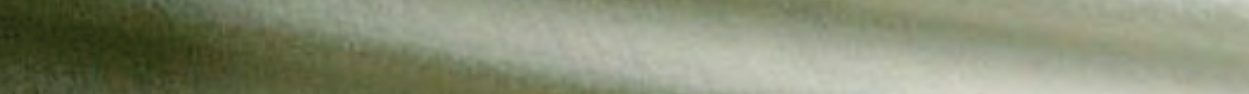

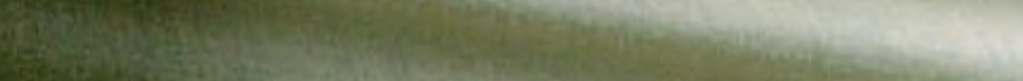

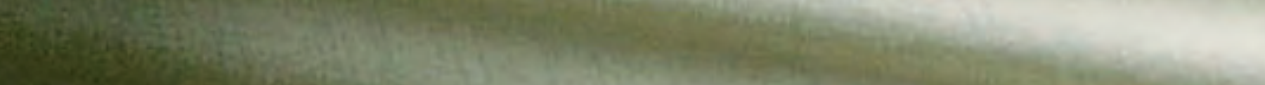

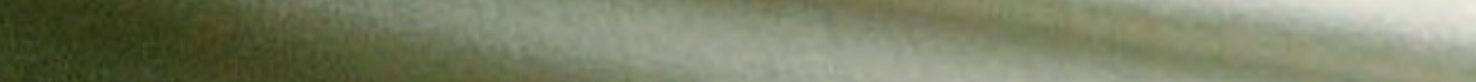

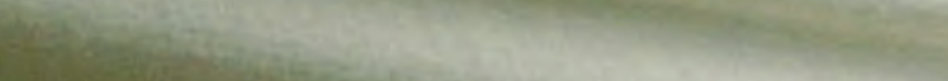

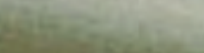




\section{ANEXOS}

\section{CASA DA MEMÓRIA DEPOIMENTOS, RELATOS, MEDIAÇÕES DOS ARTISTAS, PESOUISADORES, PROFESSORES PARTICIPANTES DA FORMAÇÃO DOS AGENTES DA MEMÓRIA}

\subsection{FREDERICO DALTON, NOVEMBRO, 2009.}

\section{Quase dois anos depois}

Para Lilian Amaral

0 filme é o seguinte (porque só consigo pensar fazendo roteiros): um fotógrafo (e não um bebê) é deixado dentro de uma caixa de papelão às portas de uma histórica vila operária no alto da serra. Fica repentinamente cego diante da paisagem nova. 0 que the traz de volta a visão é uma densa neblina que o envolve repentinamente quando atravessava a antiga ponte sobre a linha do trem.

Agora que voltou para casa, se surpreende: tenho certeza que vi a neblina se aproximando; foi um vagalhão branco e engoliu num segundo a distância entre a teleobjetiva e o lugar. Não entendo: se estava cego, como consigo me lembrar de sua aproximação? Daquela nuvem aterrissada emergiram uma mulher carregando um bebê, um homem empurrando uma bicicleta, dois rapazes. Se estávamos todos vivos, por que só eu não tinha rumo? Se éramos todos vizinhos, por que só eu não tinha rosto?

$\mathrm{Na}$ pousada onde se hospedou, o recém-chegado descobriu antes de dormir que não havia mais ninguém além dele. 0 banheiro ficava no fim do corredor. Se quisesse, podia ter saído de lá totalmente nu, brincado de louco, manchando o assoalho 
com a espuma do sabão ou da boca. Ou nada de banho: podia ter ido para cama sujo mesmo, como um operário embriagado, cansado de ser picado por insetos mal-explicados. Podia ter se incendiado com as roupas que trouxe da Inglaterra e virado cinzas que assombrariam o casarão inteiro. Podia, mas não fez. Quem se encarregou disso foram os fantasmas da casa que o esperavam na porta do banheiro e o perseguiram às gargalhadas até a porta do quarto. Tranca rápido! Conseguiu. Mas, pendurada numa cadeira, uma camisa encharcada com a chuva da tarde se recusava a secar. Muitos anos se passarão e essa pintura continuará fresca, a cena ainda estará lá: úmida, provocando o fotógrafo a transformá-la, mas ao mesmo tempo afastando sua mão.

Daquele lugar de onde se via o mar, o fotógrafo começou a se avistar. As pessoas que lá conheceu tinham a delicadeza de moradores de ilhas e a grandeza de pequenos países ladeados por superpotências. Eram todos estrangeiros como os primeiros habitantes, e no inverno também secavam as paredes com páginas de diários escritos em diversas línguas. As casas, permeáveis como olhos solitários, abrigavam ora os que conspiravam contra a passagem do tempo ora os que zombavam da fé na permanência do mundo. No eco das ruas, crianças que avisam sobre a presença de uma cobra venenosa, um cachorro que segue os turistas na chuva entre sepulturas azulejadas, um fusca impecavelmente branco, um olho d'água, uma lâmpada acesa durante o dia, a queimadura de taturana no pescoço de um rapaz.

Volto à minha cidade de multidões e minha caixa de papelão agora é um desajeitado trailer que não estaciona bem em lugar nenhum. Os ruidos da metrópole interrompem minhas memórias de uma cidade pequena.

Rio de Janeiro, 13 de novembro de 2009 


\subsection{SONIA MARIA FREITAS}

\section{Memória e a arte de (re)memorar}

Como especialista no tema da memória e da História Oral, já realizei mais de cinco dezenas de cursos no país, com finalidade de incentivar o resgate da história local. Devo confessar que a experiência na Vila de Paranapiacaba foi muito marcante, por alguns motivos. Primeiro, na minha memória sua imagem estava relacionada ao glorioso passado da Vila, pois como estudiosa do tema da imigração para São Paulo, meu olhar passou várias vezes pelos trilhos da ferrovia que trazia imigrantes do porto de Santos. $\mathrm{Na}$ segunda camada da memória a imagem era fotográfica e fantasmagórica, permeada por mortos-vivos da ferrovia, almas penadas vagando pela cidade cuja neblina, sempre presente, encobria rostos e lágrimas. Talvez esta imagem tenha sido reforçada pelo filme 'Doramundo', dirigido por João Batista de Andrade em 1978. Nele ocorre uma série de misteriosos assassinatos, na pequena e oprimida vila da Cordilheira.

Por tudo isso, aceitei de pronto o convite da Curadora da Casa da Memória, Lilian Amaral, pessoa que eu já tinha o maior respeito como artista e arte educadora e pela sua sensibilidade no olhar para coordenar um workshop para os futuros agentes da memória de Paranapiacaba.

Como mediadora das memórias, posso concluir que o curso foi um momento em que o passado veio à tona mostrando conflitos, traumas, brincadeiras, festas, alegrias. Sociabilidade. Trabalho, ruídos, paisagem. À medida que as pessoas iam mergulhando em suas lembranças, como num transe, mergulhavam num clima meio catártico. Velhos e jovens transitando entre passado e presente buscando o seu lugar. Houve ali um importante momento de reflexão sobre o atual estatuto e o futuro da Vila.

Esta oficina processual colaborou na capacitação dos agentes da 
memória - monitores ambientais e culturais como interlocutores entre o passado e o presente, o individual e o coletivo, a micro e a macro história. Eles foram a campo registrar depoimentos de jovens e velhos, visando a implantação da Casa da Memória. Nas narrativas dos moradores da cidade, o imaginário misturava-se às histórias vividas: os mais velhos tiveram que reinventar-se nas novas perspectivas do lugar; no discurso dos jovens artistas percebe-se o embate com os antigos para demarcar o seu espaço e mostrar a sua arte. Além disso, o curso possibilitou o envolvimento dos agentes da memória com alguns moradores da Vila e um mergulho na história do lugar, e também se tornou um espaço de reflexão sobre como melhorar as suas práticas artístico-culturais, incentivando a preservação do patrimônio histórico-cultural da cidade.

Enfim, os agentes da memória criaram um importante acervo de depoimentos orais, que enriqueceram com suas faces, cores e vozes com o projeto maior - A Casa da Memória - um museu a céu aberto.

Dra. Sônia Maria de Freitas

Historiadora 


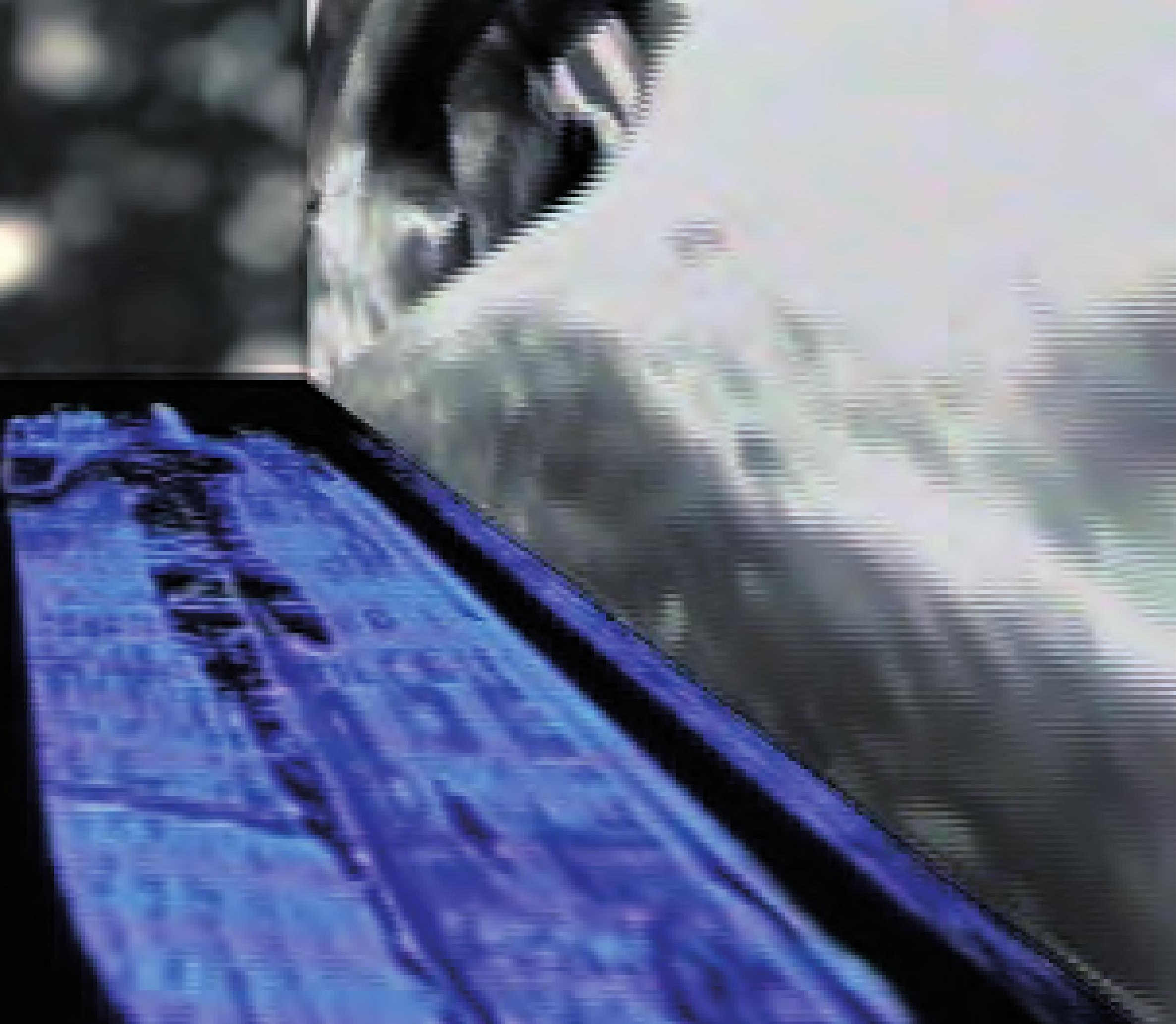




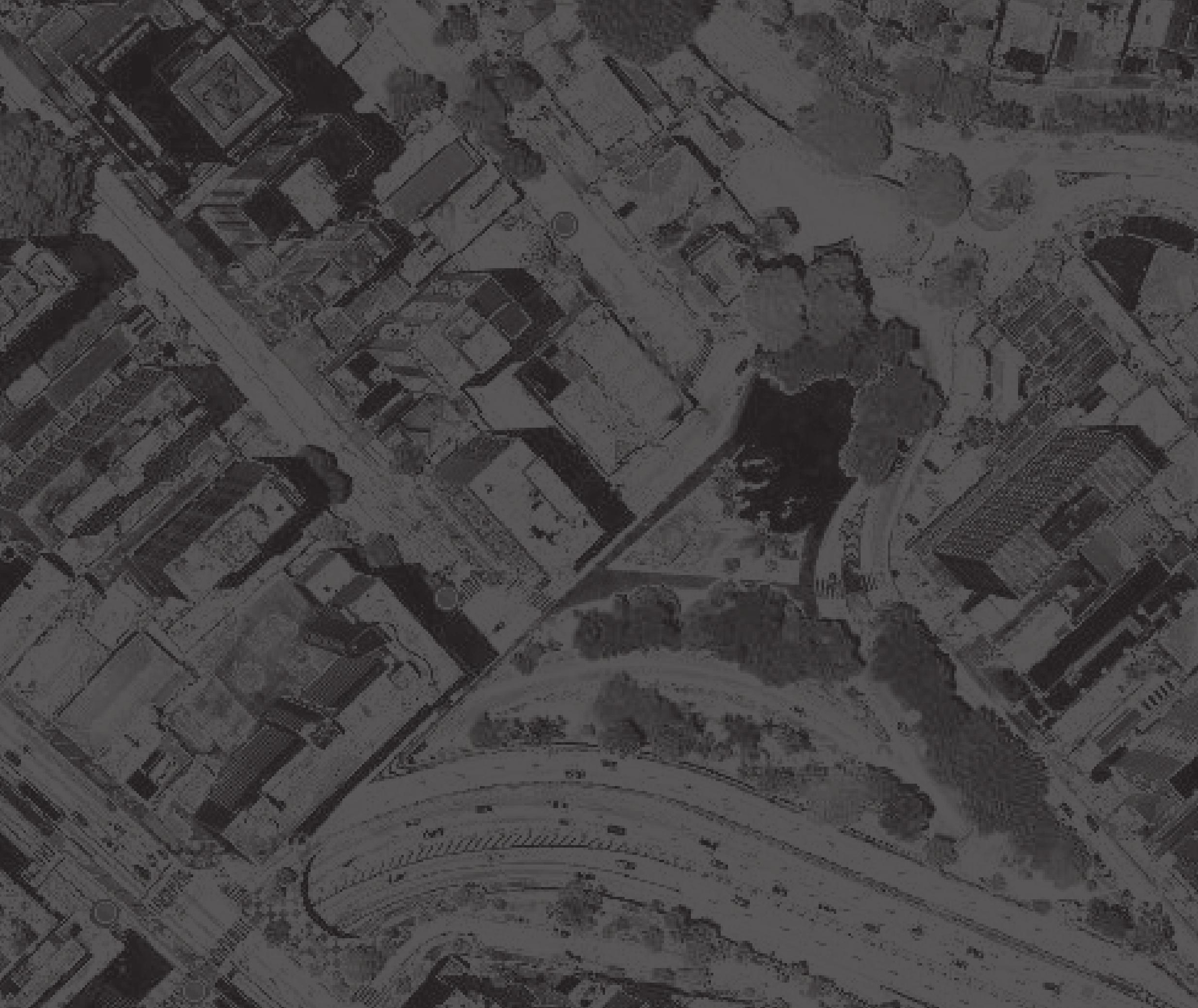

